\title{
أهل الحل والعقد \\ دراسة في المفهوم والنشأة وإمكانات الثطبيق في العصر الحديث
}

المختار الأحمر

$$
\begin{aligned}
& \text { الملخص }
\end{aligned}
$$

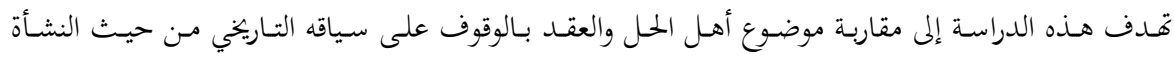

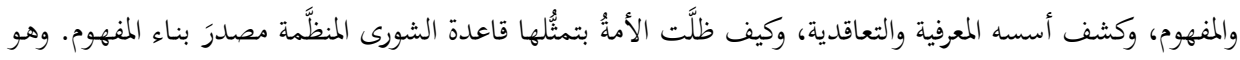

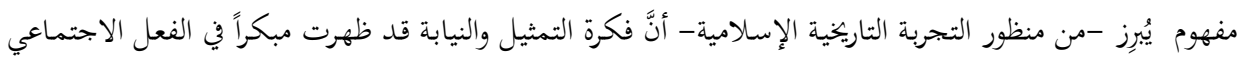

$$
\begin{aligned}
& \text { والسياسي الإسلامي. } \\
& \text { مددف الدراسة أيضاً إلى البحث في علاقة مفهوم أهل الحل والعقد بما تطرحه نظرية النظم السياسية الحديثة، }
\end{aligned}
$$

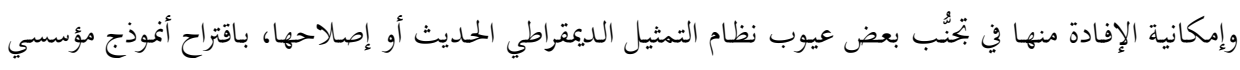

$$
\begin{aligned}
& \text { يُعبِّ عن مضمون هذا المفهوم. } \\
& \text { الكلمات المفتاحية: الحل والعقد، الشورى، الأُمّة، النيابة، البيعة. }
\end{aligned}
$$

\section{Ahlu al-Hall wa al-A'qd (The members of the Parliament): \\ A study on the concept, origin and potential applicability in contemporary time}

\section{Abstract}

This study aims to approach the traditional Islamic concept called "Ahlu al-Hall wa al-A'qd" that may be considered today as members of the parliament by investigating the historical context in terms of origination, revealing its conceptual and contractual foundations and how the nation (Ummah) has been the source of building the concept through the systematic practice of consultancy (Shura). Besides, in the Islamic historical experience, this concept shows that the idea of representation and deputation have appeared early in the Islamic social and political action.

Furthermore, the study examines the relationship of the concept of "Ahlu al-Hall wa al-A' $q d^{\prime \prime}$ with the theory of modern political systems and explore the possibility of using it to avoid or reform some of the defects of the modern democratic representation system by proposing an organizational model that reflects the essence of this concept.

Key words: Ahlu al-Hall wa al-A'qd, Consultancy, Universal nation (ummah), Deputation, Allegiance.

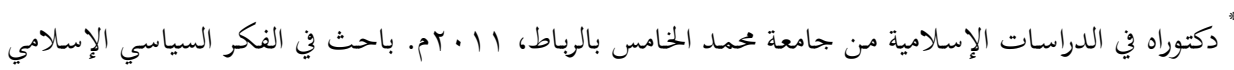

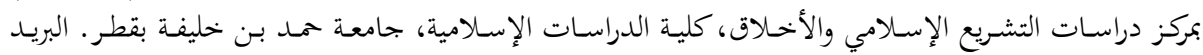

$$
\begin{aligned}
& \text { الإلكتروني: mokhtarabdi@ hotmail.com }
\end{aligned}
$$

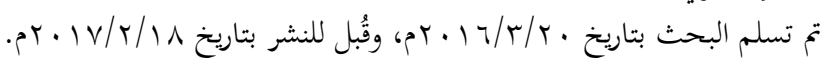




\section{مقدمة:}

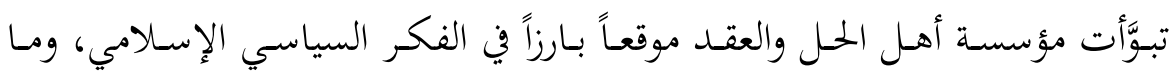

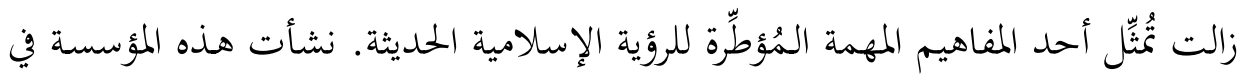

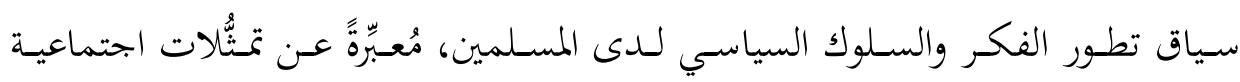

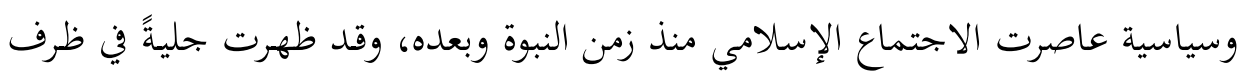

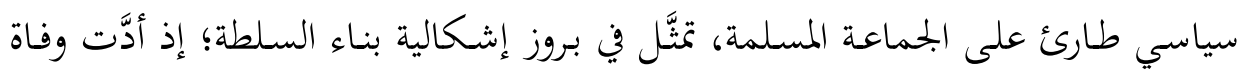

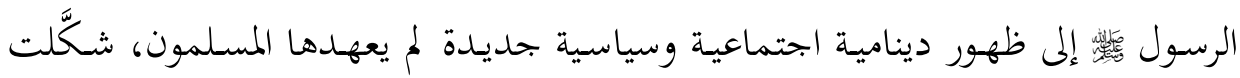

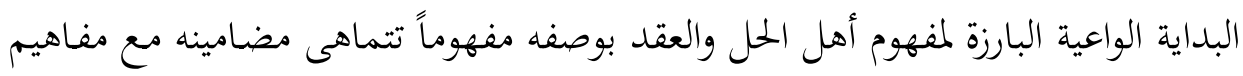

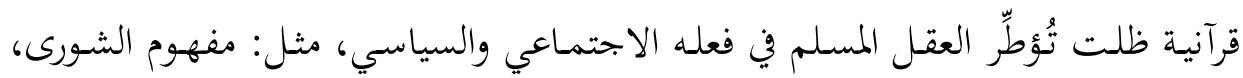
والبيعة، وأولي الأمر، وغير ذلك.

صحيح أنَّ هـذه المؤسسة تُمثِّل أسلوباً أنتجهه العقل المسلم لتفويض السلطة -وإِنْ

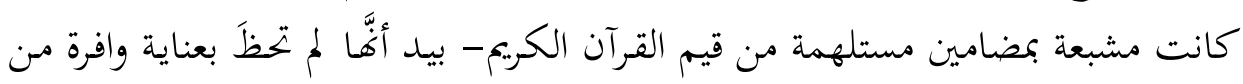

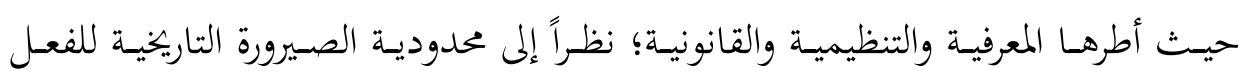

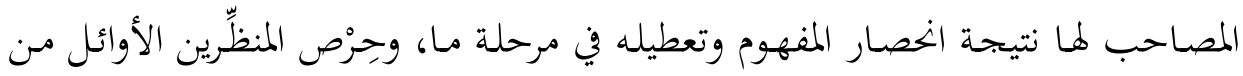

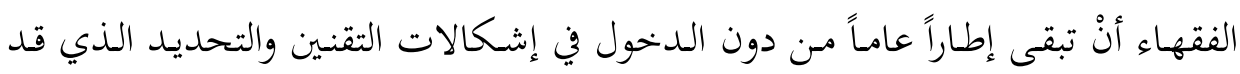

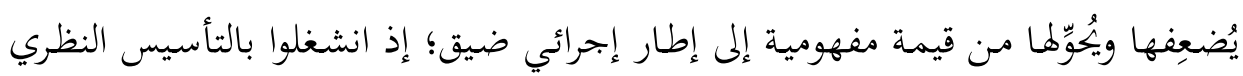

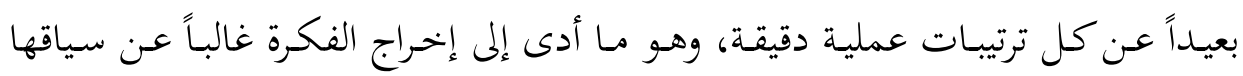

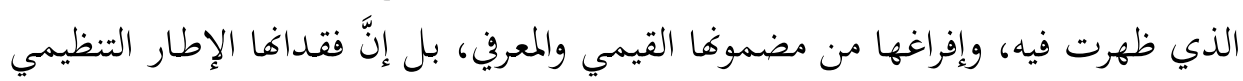
والقانوني جعلها عرضة لكل التأويلات ذات النزعات التسلطية.

وعلى هذا، فقد ظل مفهوم الحل والعقد في التجربة التاريخية الإسلامية مفهوماً عاماً

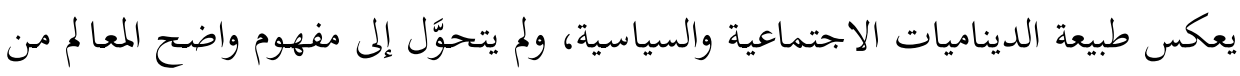

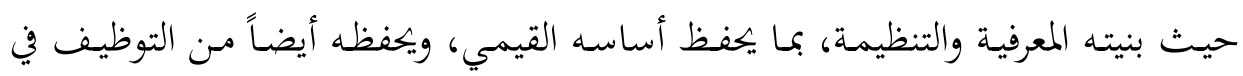

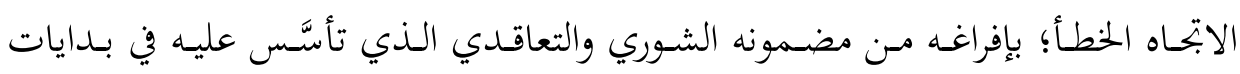

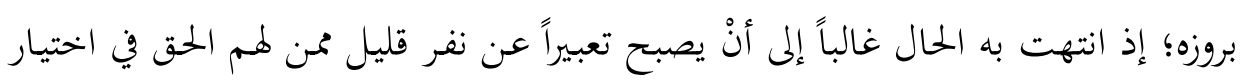




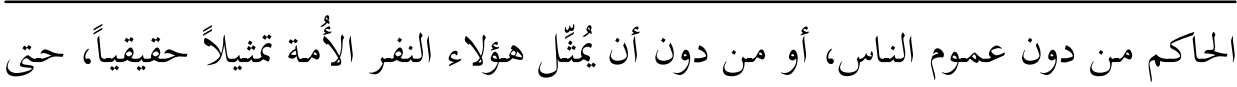

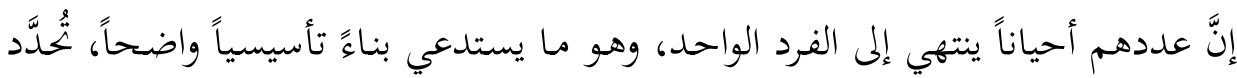
أبعاده الوظيفية، وأطره المعرفية من قيم القرآن الكريم، ومن بحربة المبردية المسلمين التاريخية. ولهذا سنبحث الموضوع من زاوية مفاهيمية تربطه بأصوله المعرفية والتاريخية من دون

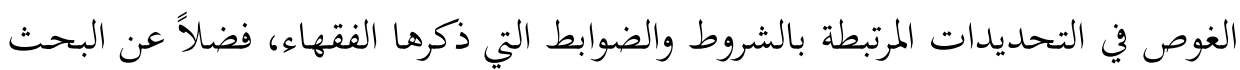

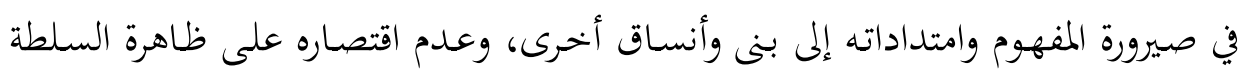

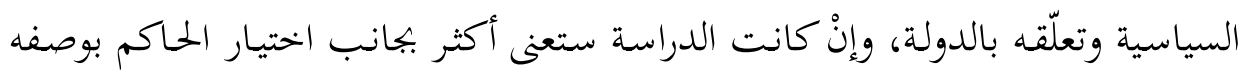

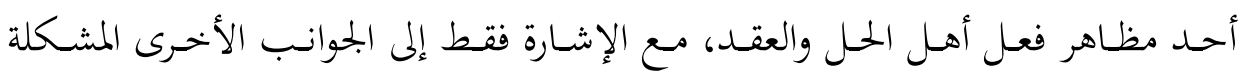
للمهام التي يستوعبها المفهوم. وتسعى هذه الدراسة إلى استكشاف إمكانات منهجية ومفهومية جديدة في مقاربة

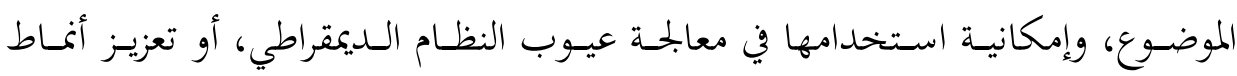

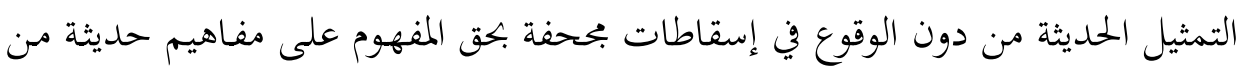
غير ملاحظة التمايزات الحاصلة بينهما. وهذه بعض الأسئلة الملحّة التي تبحث عن إجابات شافية ونحن نقارب هذا الموضوع

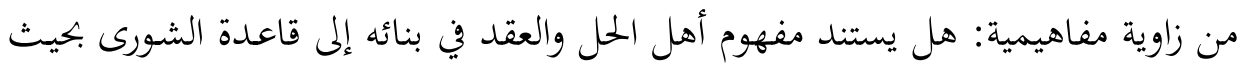

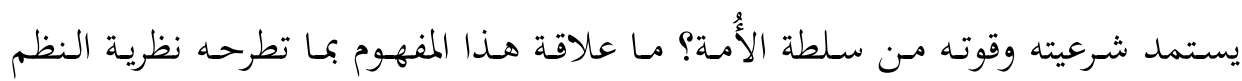

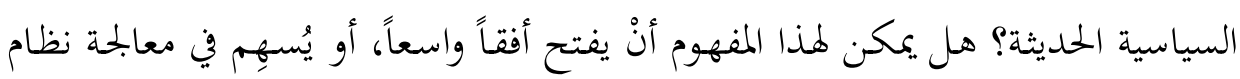

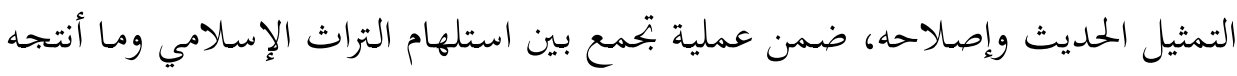

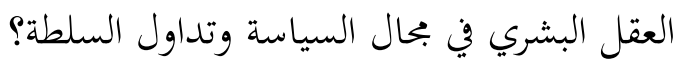

\section{أولاً: مفهوم أهل الحل والعقد}

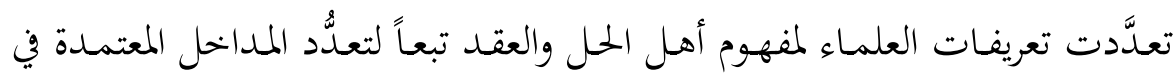

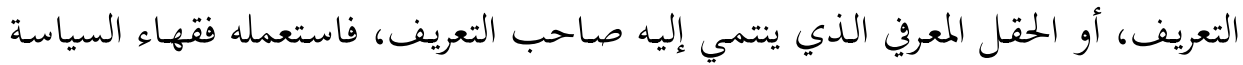


الشرعية وعلماء الكلام في باب الإمامة السياسية، في حين استعمله علماء الأصول في لئ

$$
\text { باب الإجماع. }
$$

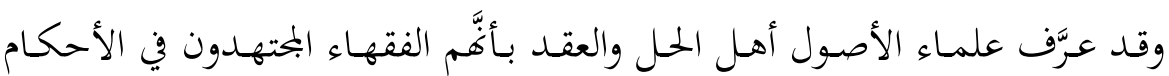

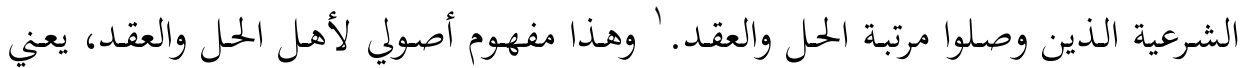

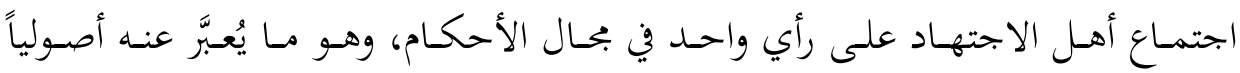
بالإجماع.

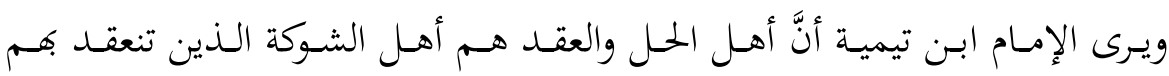

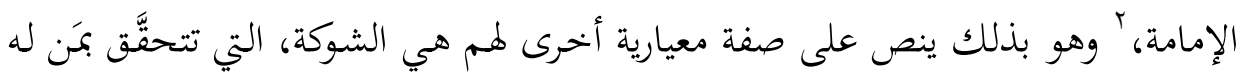
القدرة والسلطة؛ سواء أكانت فكرية أم سياسية.

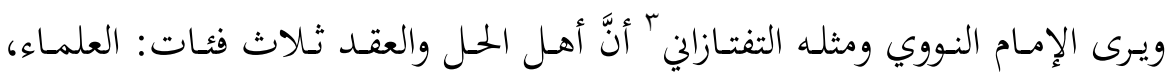

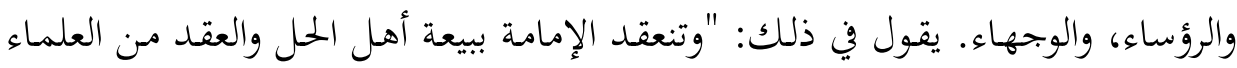

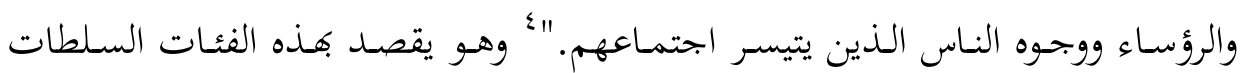

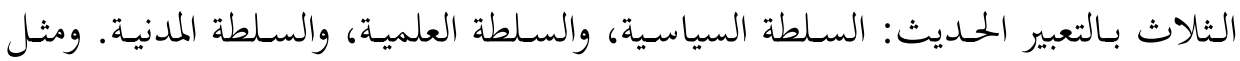
ذلك قول ابن جماعة: "الطريق الأول في الاختيار بيعة أهل الحل والعقد من الأمراء والعلماء

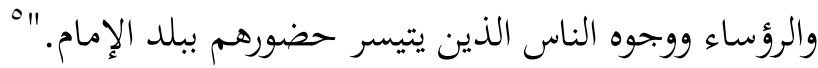

- الرازي، فخر الدين. المحصول في علم أصول الفقه، تحقيق: طه جابر العلواني، بيروت: مؤسسة الرسالة،

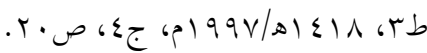

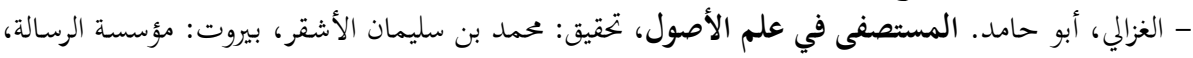

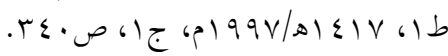

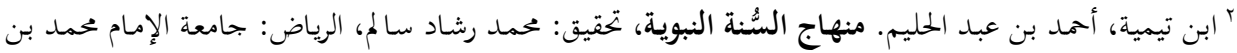

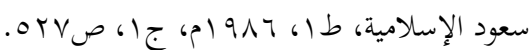

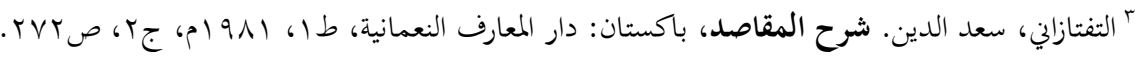

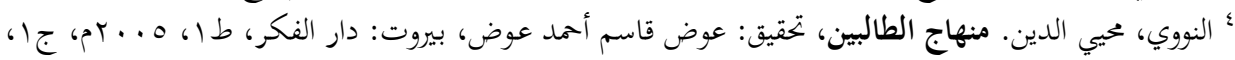

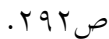
"إبن جماعة، بدر الدين. تحرير الأحكام في تدبير أهل الإسلام، تحقيق: فؤاد عبد المنعم أمد، الدوحة: دار الثقافة، 
وإذا نظرنا في كلام مُنظّري السياسة الشرعية الأوائل، أمثال الماوردي وأبي يعلى الفراء

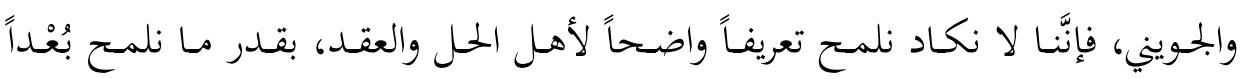

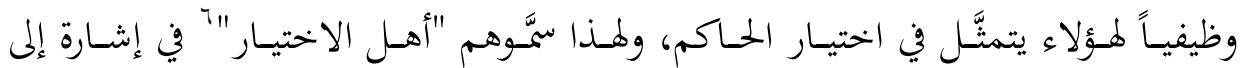
الجماعة التي تتولَّى اختيار الحاكم. فئمئ.

ولإمـام الجويني شرط أساسي في أهل الحل والعقد، هو الاستقلالية في القرار، فلا

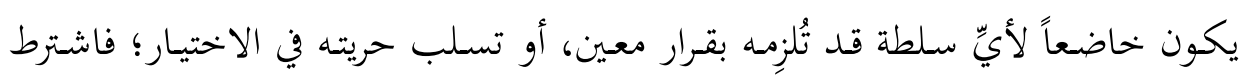
فيهم امتلاك الحرية في اتخاذ القرار، والحنكة المستقاة من كثرة التجارب؛ إذ عرَّفهم بقوله:

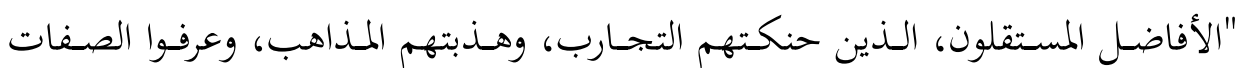
المرعية فيمن يناط به أمر الرعية. ل

ويرى ابن خلمدون أنَّ أهـل الحل والعقد هـم الذين يمتلكـون العصبية اللازمـة للقيـام بمهمة الحل والعقد؛ إذ قال: "الشورى والحل والعقد لا تكون إلا لصاحب عصبية يقتدر

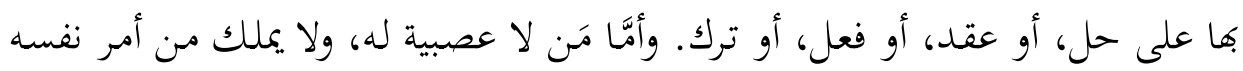

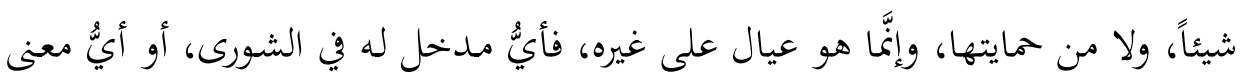

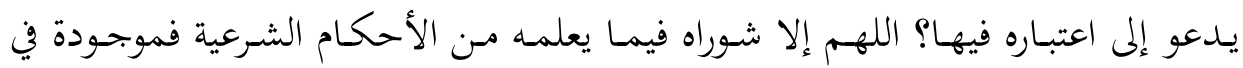

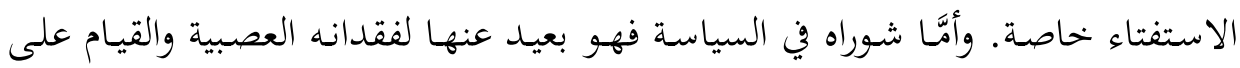

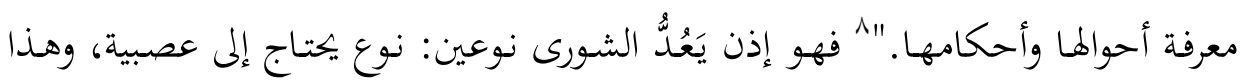

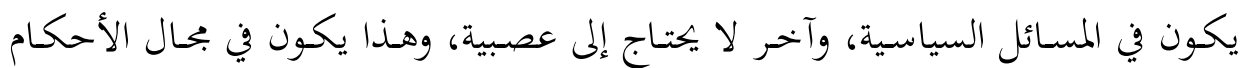
الشرعية والإفتاء؛ فهو يشترط في أهل الحل والعقد صفة العصبية. ومن التعريفات الحديثة لأهل الحل والعقد التي جمعت بين استدعاء المفاهيم القديمة

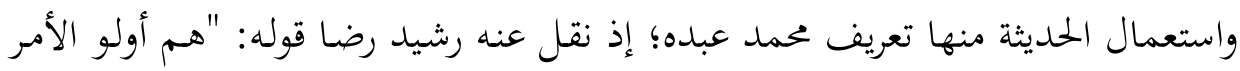

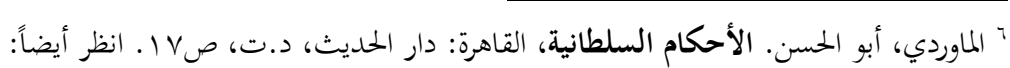

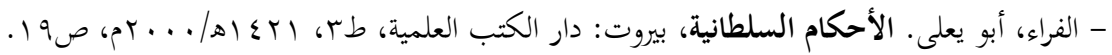

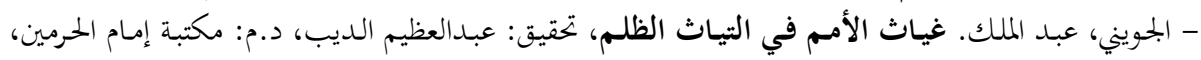

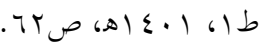

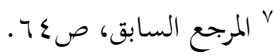

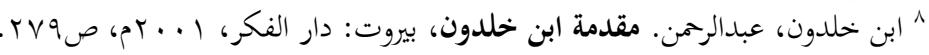




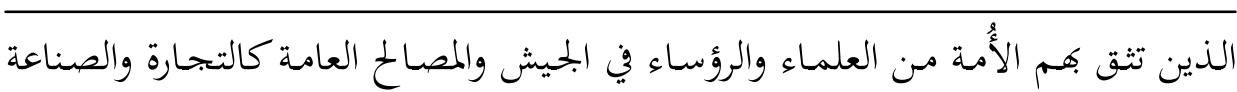

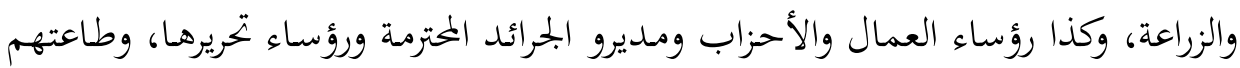

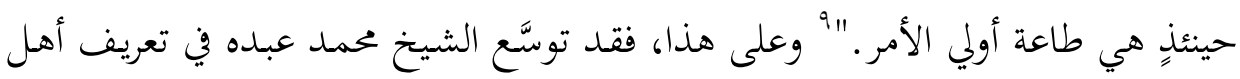

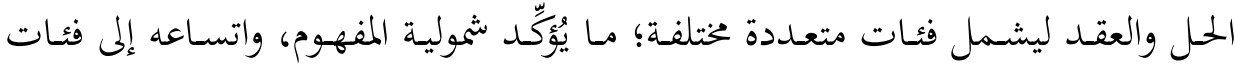
علَّة.

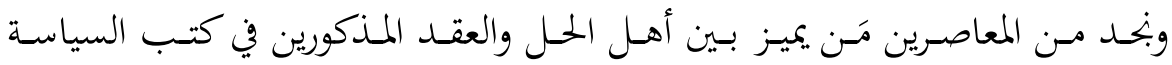
الشرعية وعلم الكلام، وأهل الحل والعقد المذكورين في كتب عُبن علم الأصول، مُظهِرِاً التمايز

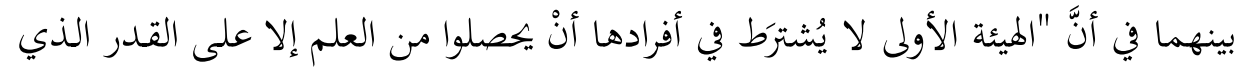
يُوْهِّلهم لأنْ يكونوا عارفين بظروف المحتمع وأحواله السياسية، قادرين على اختيار الأصلح

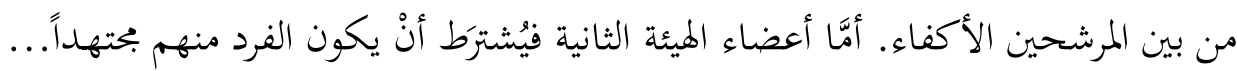

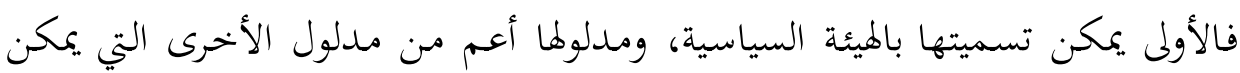

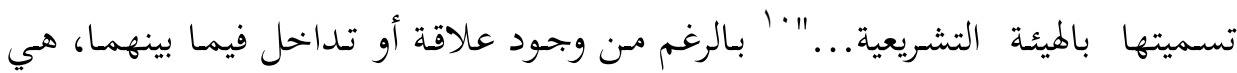
علاقة الجزء بالكل.

وبنـاءً على هذا العرض المختصر لمفهوم الحل والعقد، يمكننـا أنْ نلمـح خطّاً ناظماً لأغلب التعريفات، ومفهوماً جامعاً مُستغرقاً عدداً من المفاهيم الجزئية، هو النظر إلى ألى أهل

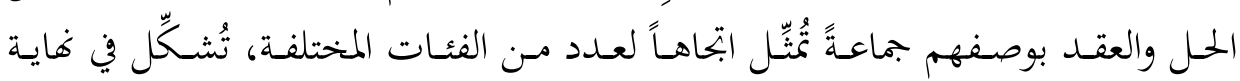
المطاف ثلاث سلطات أساسية، هي: العلمية، والاجتماعية، والسياسية. وهذه السلطات

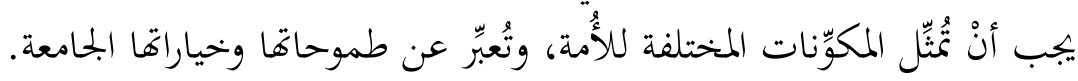

\section{ثانياً: نشأة مفهوم أهل الحل والعقد}

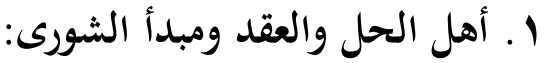

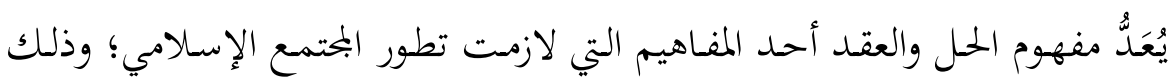

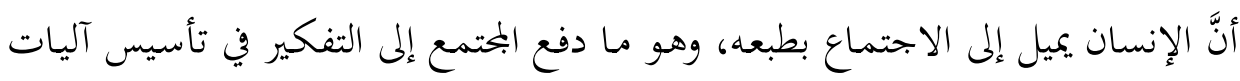

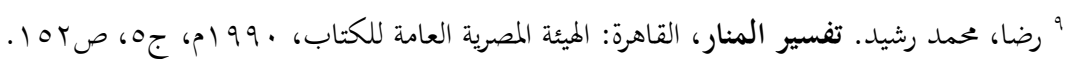

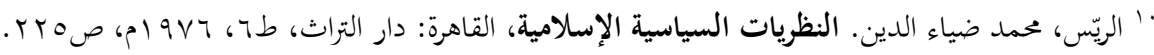


هـذا الاجتمـاع، بمـا يخـــم حاجحاته وغاياتـه المختلفـة. ولهـذا بـرز مفهـوم التمثيـل بوصفهـ إحدى الحاجات الاجتماعية والسياسية. وقد امتد هذا التمثيل ليشمل علدَّة بنى اجتماعية

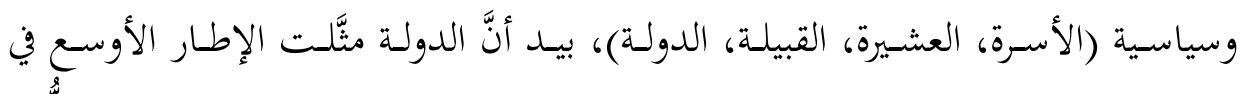

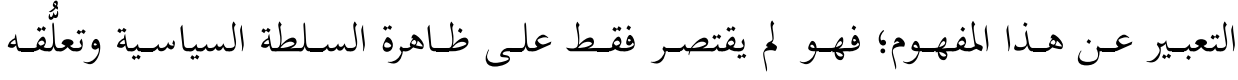

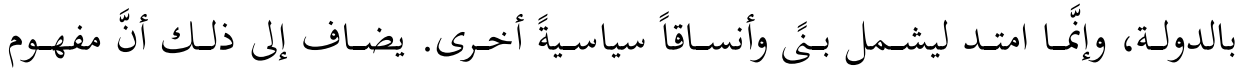

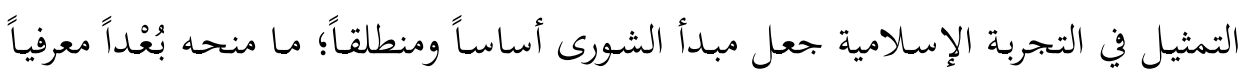
حافظ على وجوده خلال التجربة في أبعادها الاجتماعية والسياسية. صـحيح أنَّ فكـرة أهـل الحـل والعقـد في الـتراث الإسـلامي هي فكـرة مسـتحدثة -

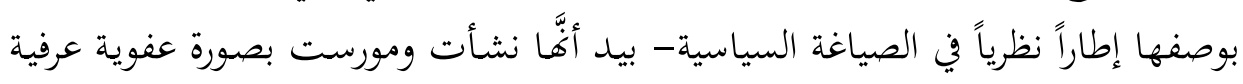

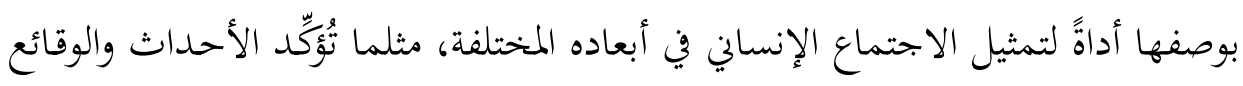

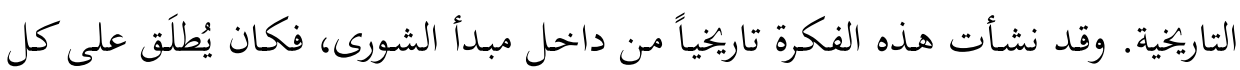

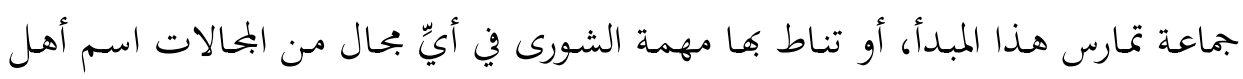
الشورى، بمَن في ذلك مَن يختص باختيـار الإمام والعقد له. وقد بقي هذا التعبير يُطلَق

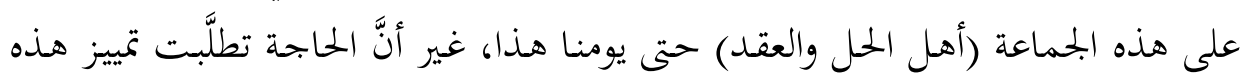
الجماعة من أهل الشورى عن غيرها، بحيث يناط بها مهمة اختيار الإمام، وتتميز بالقدرة

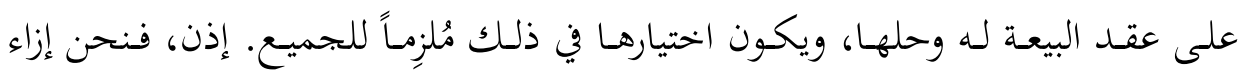

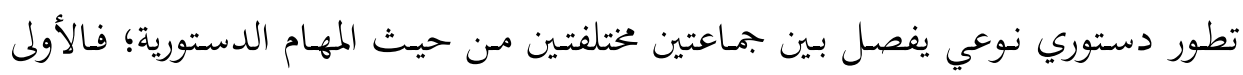

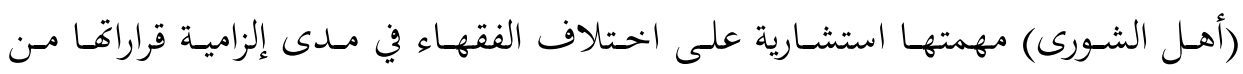

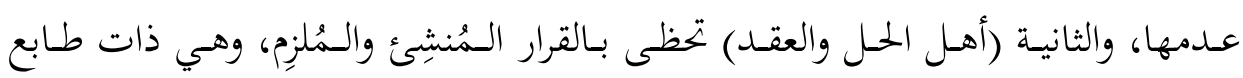
سياسي.

ومـن أجل التنبيه على ذلك التمايز في المهام بـين الجمـاعتين المذكورتين؛ فقد ظهر

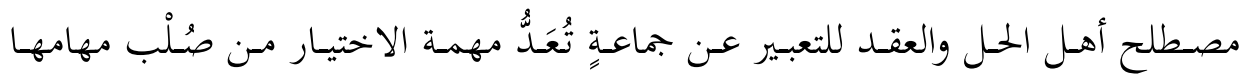
السياسية، وهو تعبير من إبداع علماء السياسة الشرعية مثلما عبَّ عنه بعض الباحثين؛ إذ

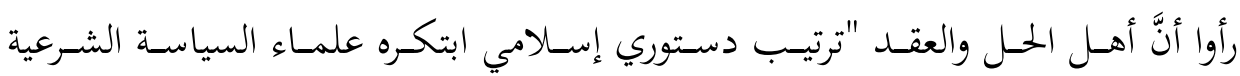


المسـلمون، وليس عليـه نص صريح لا في القـرآن ولا في السُّـنة،" "إِ وإن كانـت مضـامينه مستلهمة من مفاهيم قرآنية، ومن التجربة الإسلامية في بُعْديها: الاجتماعي، والسياسي. وتأسيساً على ذلك، يمكن القول بأنَّ مفهوم أهل الحل والعقد هو تعبير عن فلسفة تنظيمية مبتكرة ظهرت بوصفها نتاجـاً لتطوير نظام أهـل الشورى في أبعاده الاجتماعية والسياسية، ولا سيما في بحال الإمامة واختيار الحاكم؛ إنَّه مفهوم أبدعه علماء السياسة

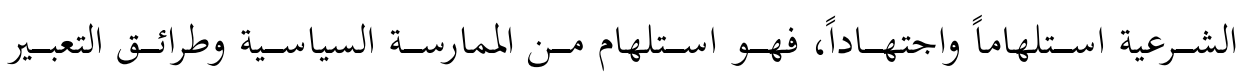

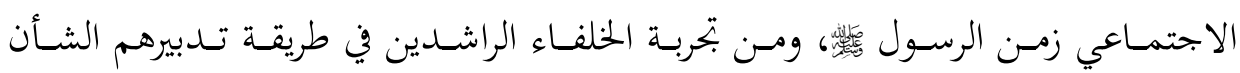

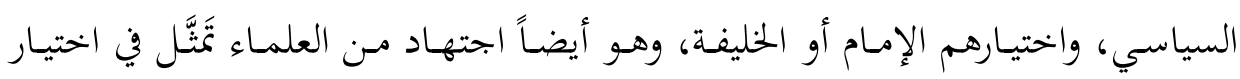
التعبير المناسب والدقيق لهذه الجماعة.

إذن، ظهـرت فكـرة أهـل الحـل والعقـــ ونشـأت في سـياق اجتمـاعي ارتـبط بدايـةً بـديناميات تـدبير الحيـاة الاجتماعيـة بوصفها آليـة لتصـريف الفعـل الاجتمـاعي وتنظيم

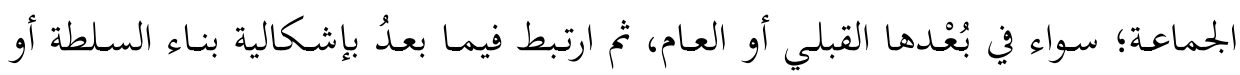

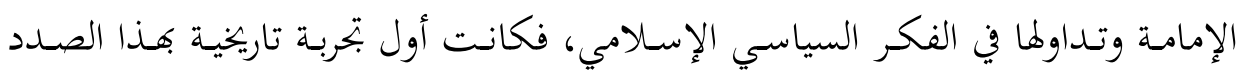

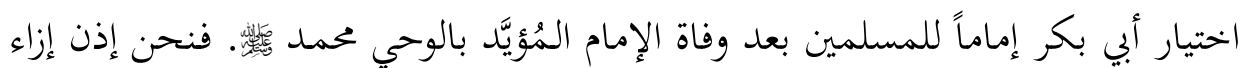
إجراء تنظيمي وتنفيذي أنتجه الفكر السياسي الإسلامي لتنظيم الاجتماع الإنساني العام

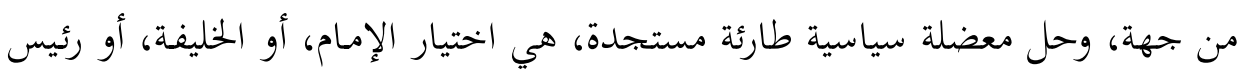

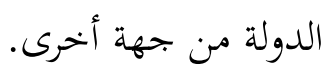

غير أنَّ هذه الفكرة -بوصفها ترتيباً قانونياً ودستورياً- أضحت فكرة نظرية ' ' فيما بعدُ، ولا سيما في البحال السياسي، فهي وإنْ كانت حاضرة في الفعل الاجتماعي وشؤون

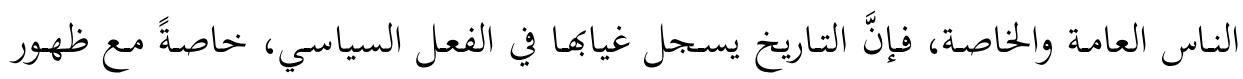

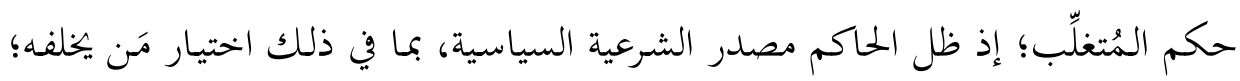

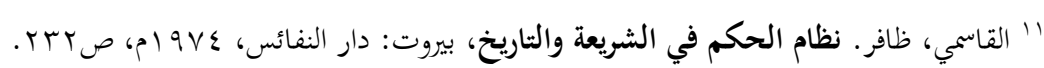

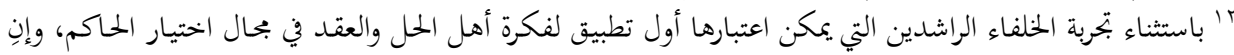

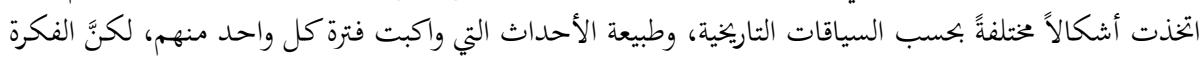
نفسها ظلت محافظة على طابعها العفوي والعرفي، ولم تتطور فيما بعلُ لتصبح ترتيباً قانونياً. 
كل هذا أدى إلى الخصار التنظير لمفهوم الحلل والعقد، وغياب امتداداته في واقع الحياة

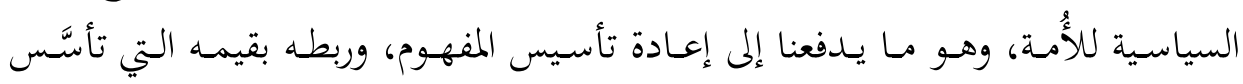

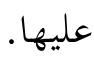

\section{Y. الطبيعة الاجتماعية والعُرفية في تحديد أهل الحل والعقد:}

اقتضت طبيعة الحياة الاجتماعية والقبَلية أنْ يكون للناس يُمثّلون معروفون بينهم وبين

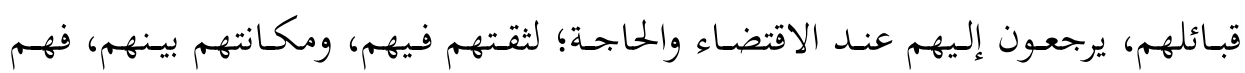

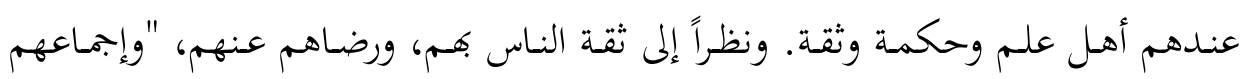

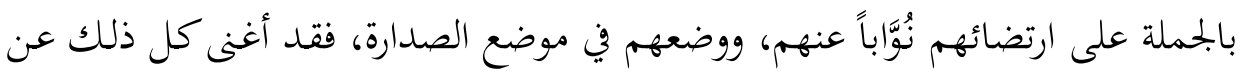

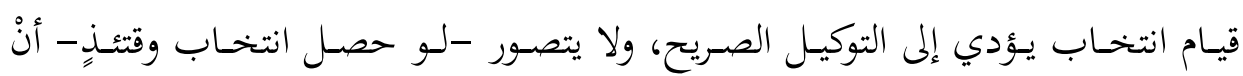

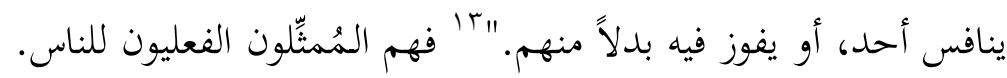

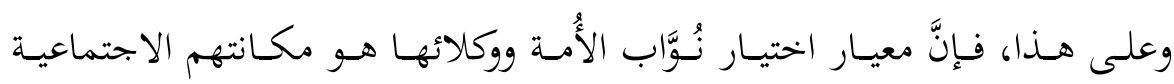

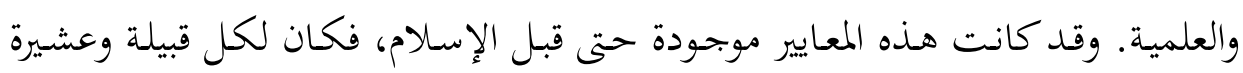

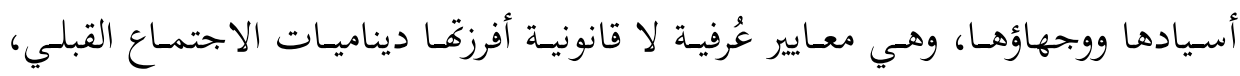

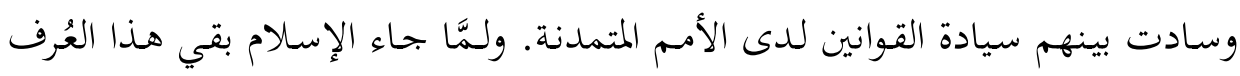

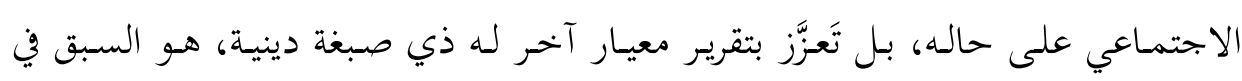
الإسلام والجهاد والتقوى والعدالة.

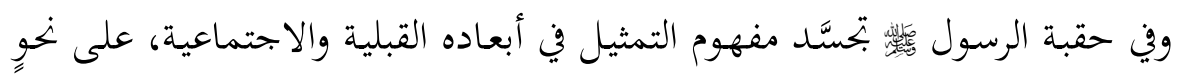

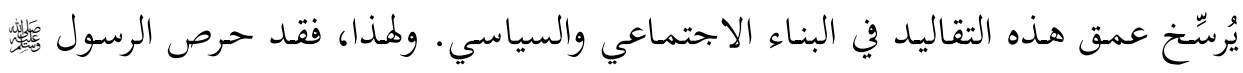

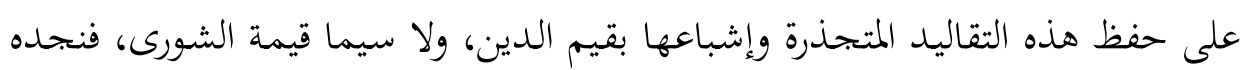

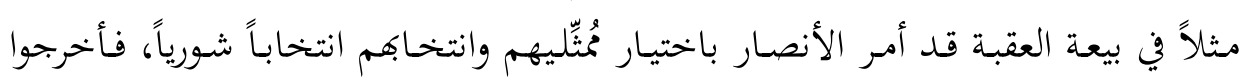

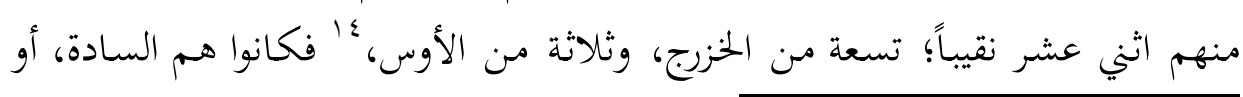

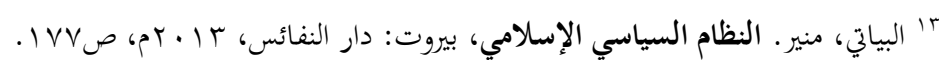

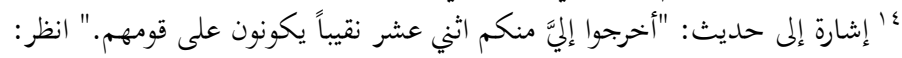

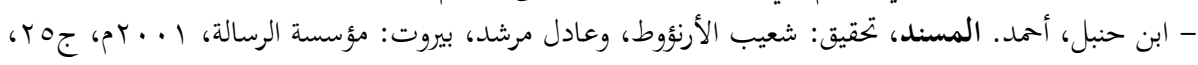

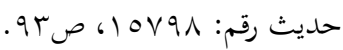


الوجهاء، أو الشرفاء منهم؛ أي إنَّم اختاروا مَن كان فيهم سيداً، أو شريفاً، أو ذا مكانة ومنزلة بينهم.

ولا شـكَّ في أنَّ وجـود هـؤلاء النقبـاء والعُرفــاء هـو نتـاج عمليـة اجتماعيـة طبيعيـة، "ونتيجة انتخاب اجتماعي تلقائي، ناجم عن مكانتهم وأهليتهم ومصداقيتهم من جهة، وعن رضا الناس بهم من جهة أخرى. فلم يكن أحد يرسلهم إليهم أو يفرضهم عليهم،

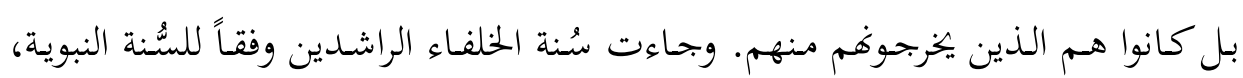

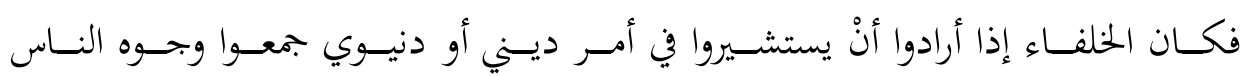

وقد ظهرت الطبيعة العُرفية والتلقائية في ممارسة الشورى في بحال الحكم عندما تويي

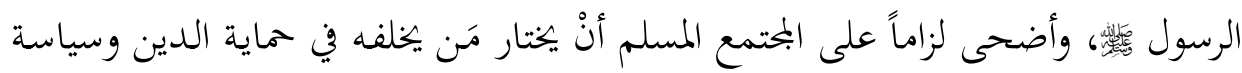
الدنيا، فاجتمع المسلمون في سقيفة بني ساعدة، وفيها تمَّت بيعة أبي بكر واختياره خليفة له؛ إذ جرت مناقشات ومشاورات كبيرة ومهمة لاختيار الخليفة، برز فيها عنصرا التمثيل القبلي لمكونات البحتمع الإسلامي، والرمزية الدينية المستمدة من صحبة النبي الكريم. وقد

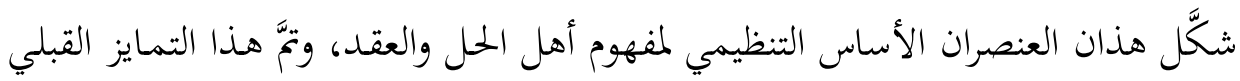

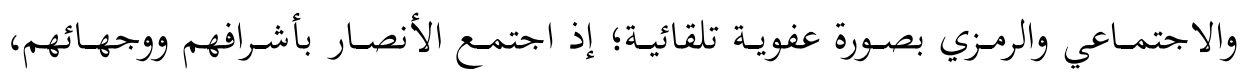
وعلى رأسـهم سعد بـن عبـادة الذي كـان موضـع السيادة بيـنهم قبـل الإسـلام وبعـده،

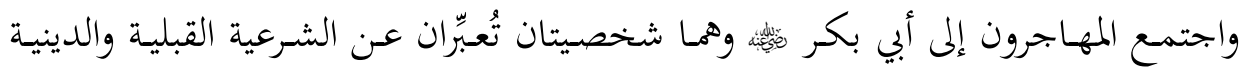
والتاريخية لمكونات هذا الاجتماع الإسلامئ. فالذين حضروا اجتماع السقيفة لاختيار الخليفـة هـم مـن أهل الحل والعقد، الذين توافدوا عليها من دون ترتيـب مسبق، ولم تكن لهم سابقة تاريخية في هذا الشـأن، أو أيُّ

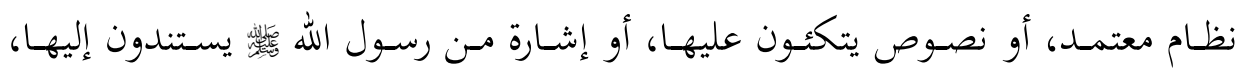

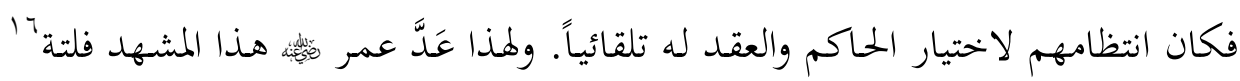

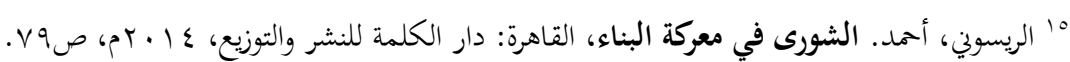

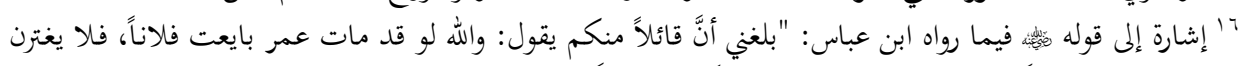

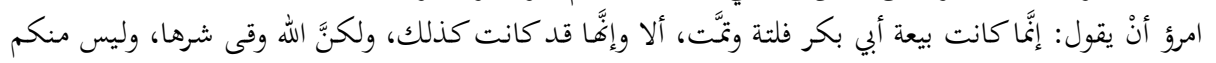




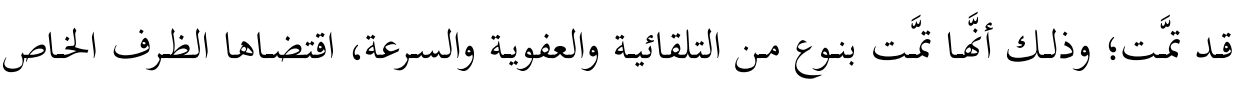

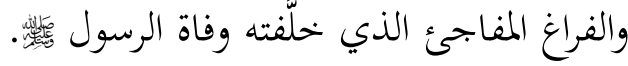
وفي إجراء تنظيمي ينمُّ عن الوعي بمكانة التشاور وخطره في الوقت نفسه، ولتجاوز

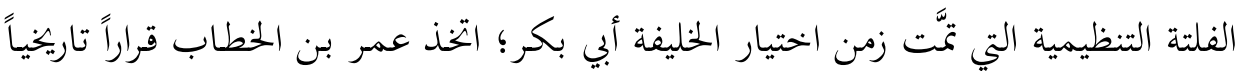

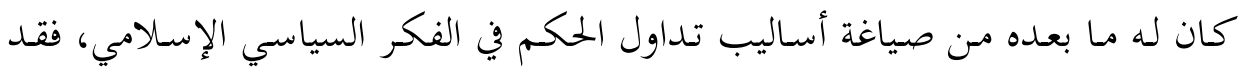

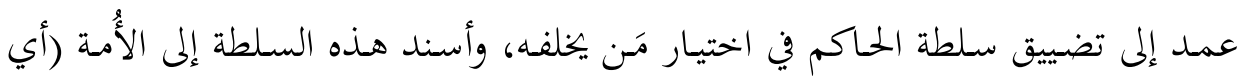

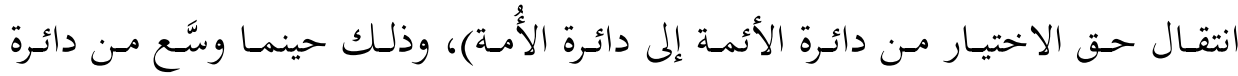

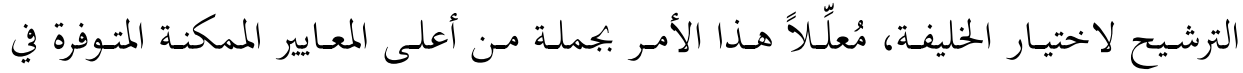

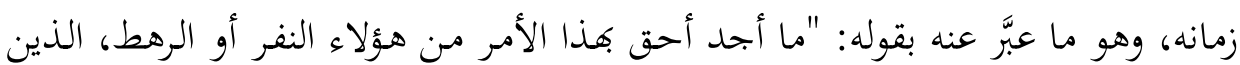
توفي رسول الله

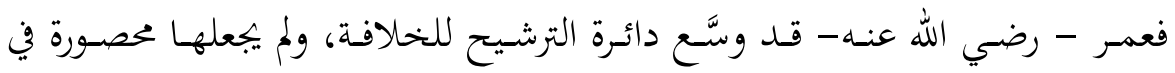

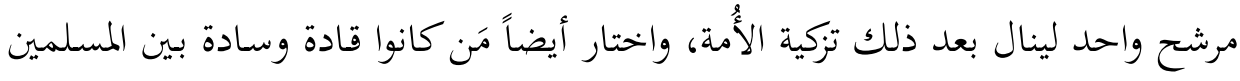

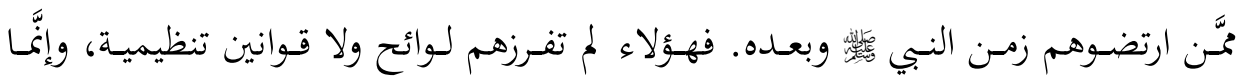

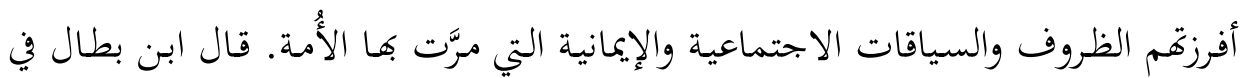

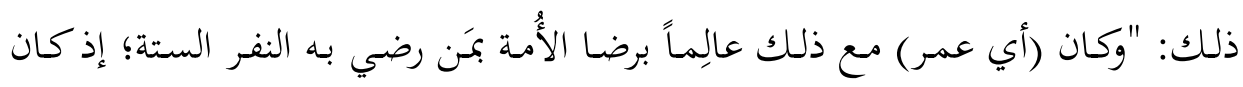

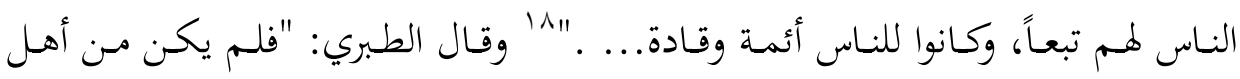

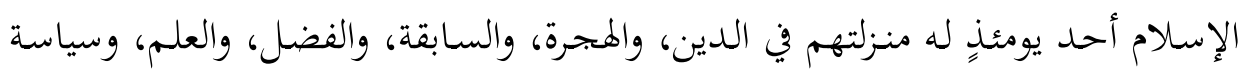
الأُمة. الإنسام 19

مَنْ تُقُطَعُ الأعناق إليه مثل أبي بكر، مَن بايع رجالاً عن غير مشورة من المسلمين، فلا يبايع هو ولا الذي بايعه

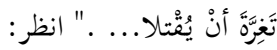

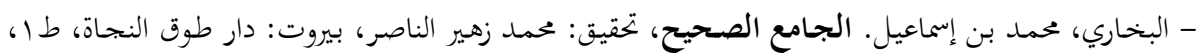

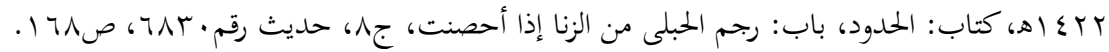

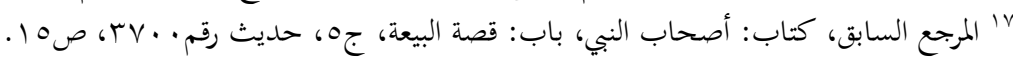

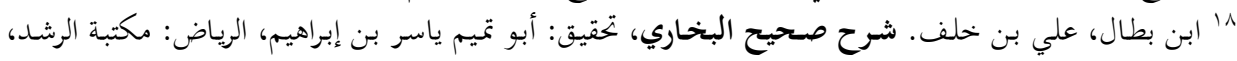

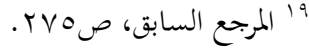


وقد كان لمذا التطور في فكر التداول على السلطة أثره البالغ في إثراء التجربة الشورية

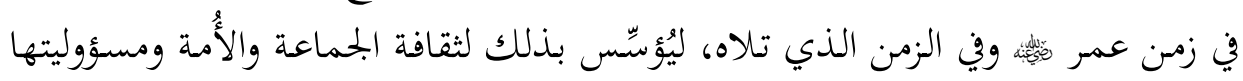

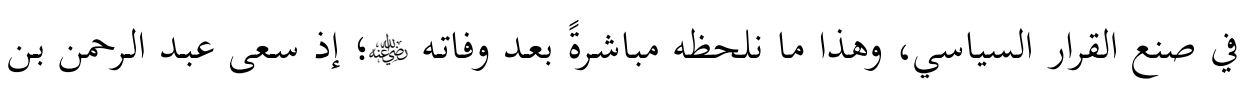
عوف إلى توسيع دائرة الشـورى في اختيار الخليفـة، فكان يستشير الجميع، حتى النساء

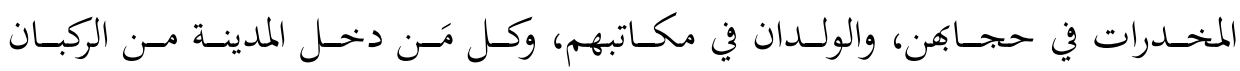

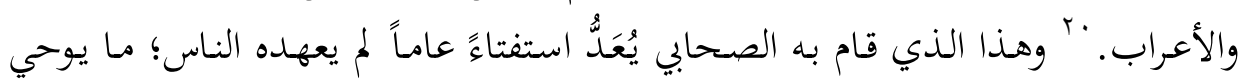

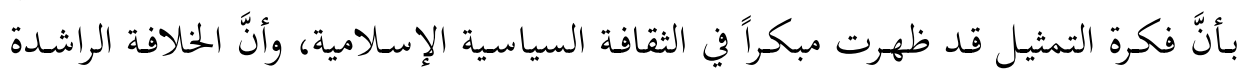

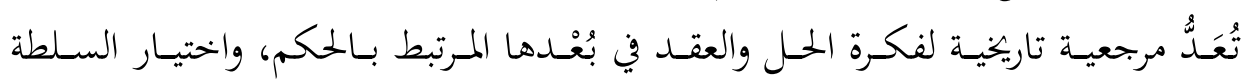
السياسية.

ثالثاً: أهل الحل والعقد والتأسيس المعرفي والتعاقدي

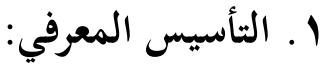

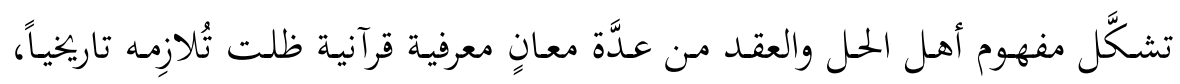

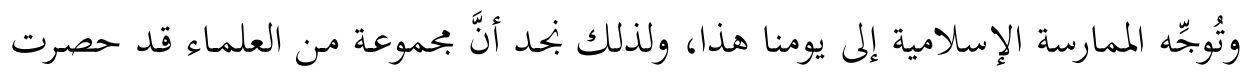

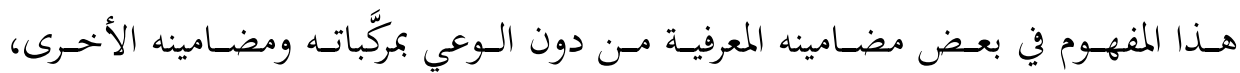

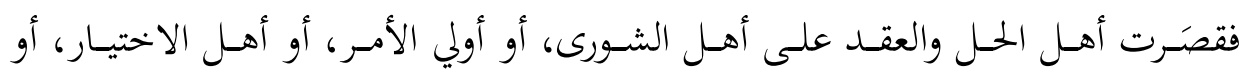

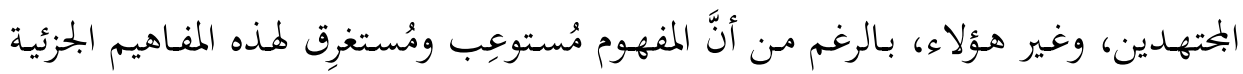
كلها.

فتسمية أهل الحل والعقد بأهل الشورى مثلاً هي تسمية ضيقة، روعيت فيها وظيفة من الوظائف المنوطة هـم، أو بفئة منهم، هي وظيفة الشورى. وتسميتهم بأهل الاختيار

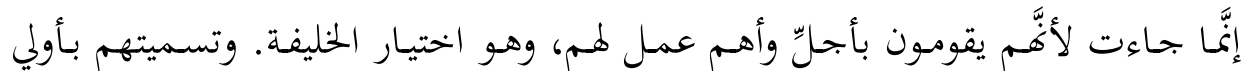

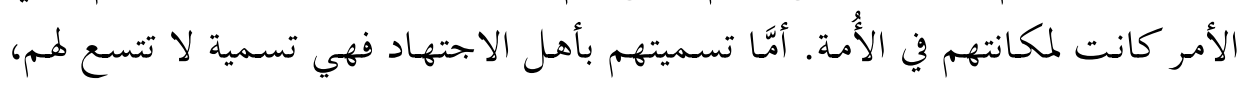

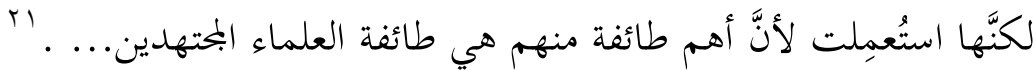

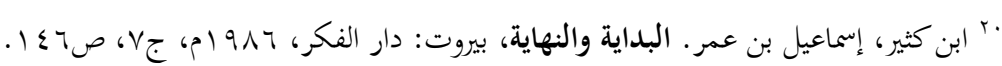

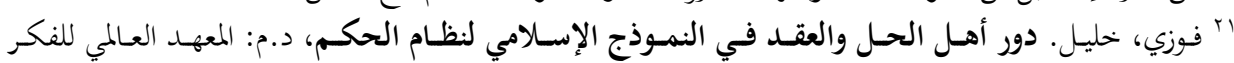




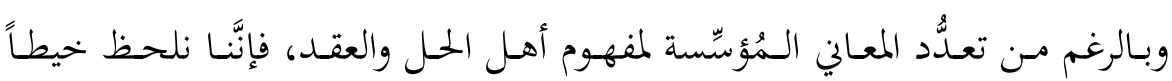

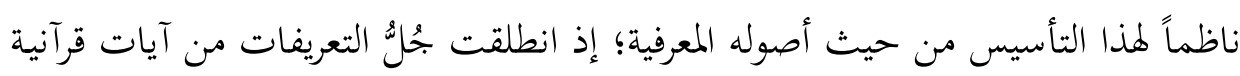
بحمعها وحدة معرفية ظاهرة، تدور حول معانٍ جزئية، تنتهي إلى صياغة معنى كلي تركيبي

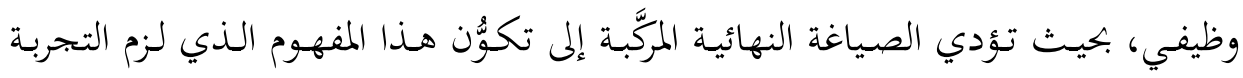

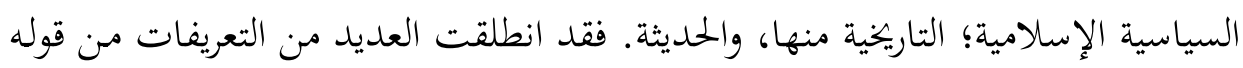

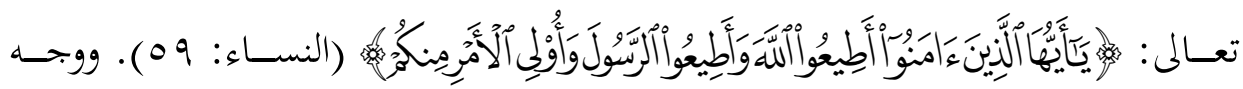

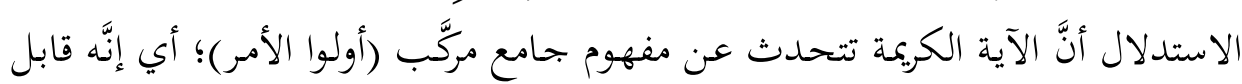

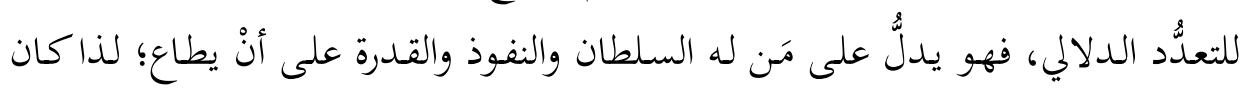

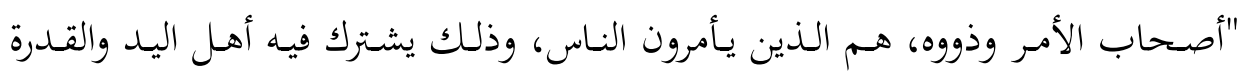

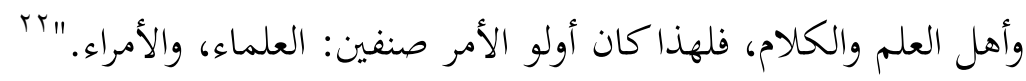

وبخد أيضاً أنَّ مفهوم النقيب هو أحد المفاهيم التي تأسَّس عليها مفهوم أهل الحل

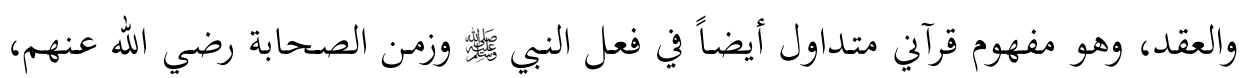

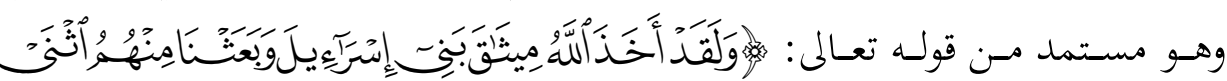

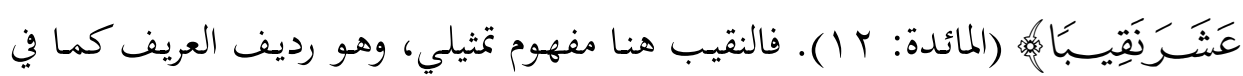

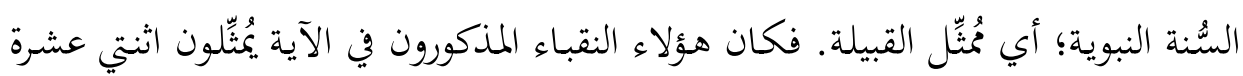

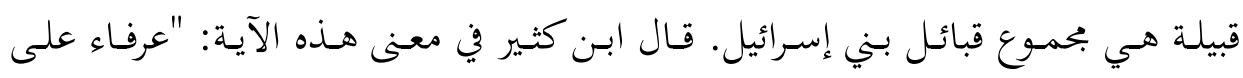

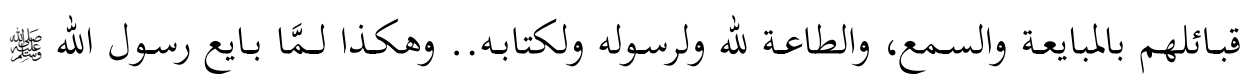

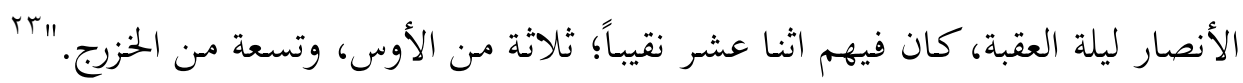

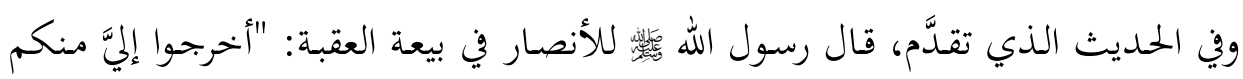

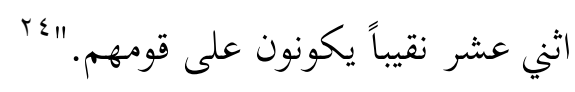

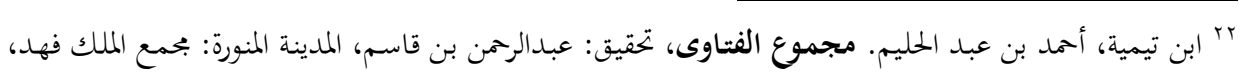
ال

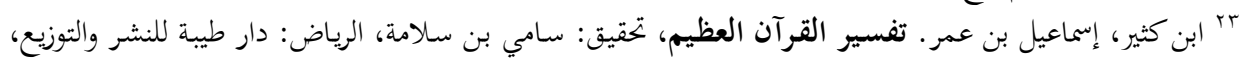

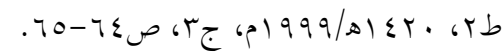

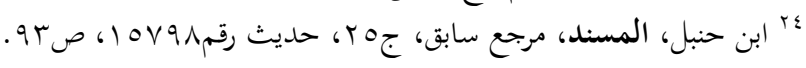




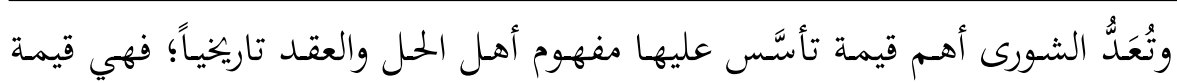

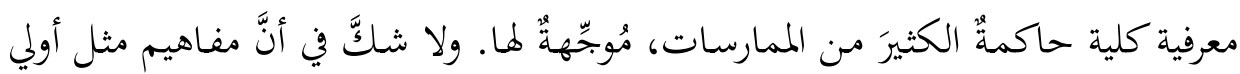

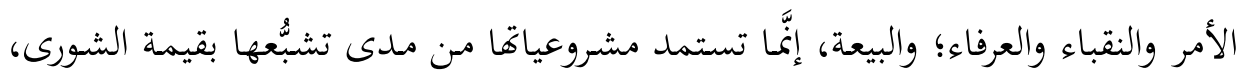
واحترام مدلولها التعاقدي، وهي في مفهومنا (أهل الحل والعقد) أَولى وألزم بوصفه مفهوماً

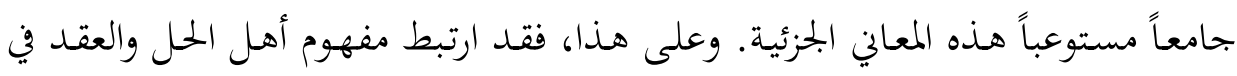
التجربة التاريخية بقيمة الشورى، وبُعْدها التعاقدي.

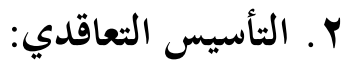

لم تأخـذ فكرة أهل الحل والعقد حقّها في التنظير الفقهي، من حيث إبراز أساسها

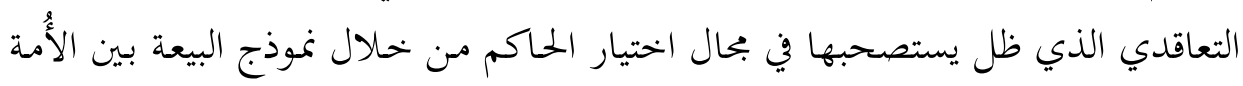
والسلطان، وما يترتَّب من حقوق وواجبات على كلٍِ منهما؛ إذ توقف الفعل التنظيري -

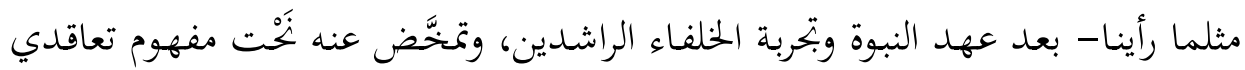

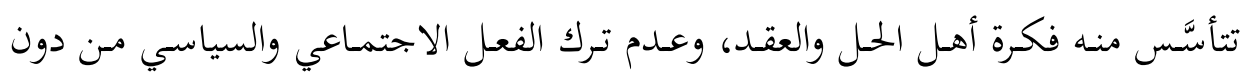

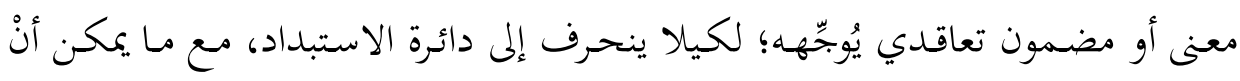
نسجله من حضور لهذا المعنى في الممارسة أكثر منه في التنظير. فبيعـة أهـل الحـل والعقــد -بوصـفها أداةً لتفـويض السـلطة في الفكـــ السياسـي الإسلامي- تُعبِّر عن مضمون تعاقدي بين متبايعينِ، فهي ليست إجراءً شكلياً يتضمَّنَ

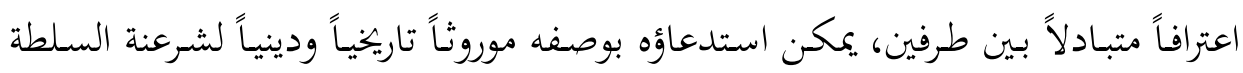

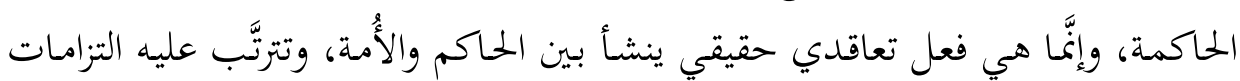

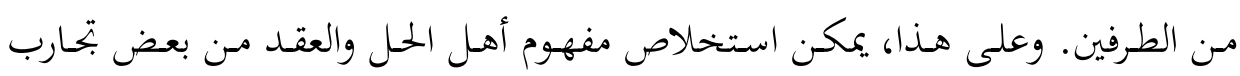

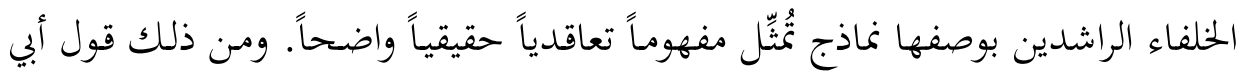

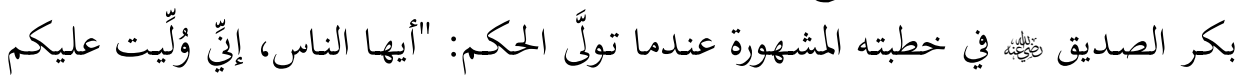

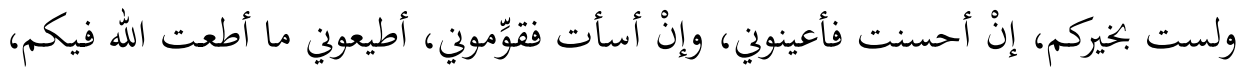

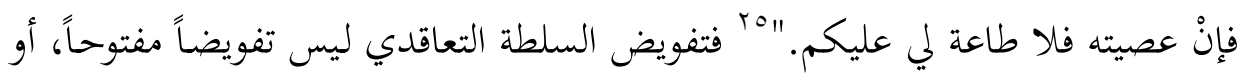
هr ب بن هشام، عبد الملك. السيرة النبوية، تحقيق: مصطفى السقا، وإبراهيم الأبياري، عبد الحفيظ الشلبي، القاهرة:

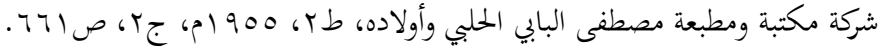




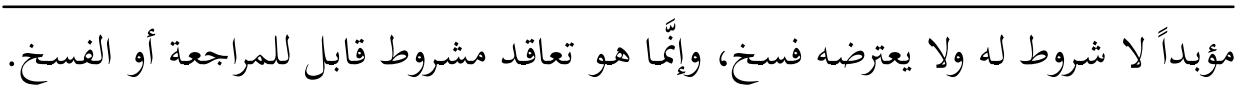

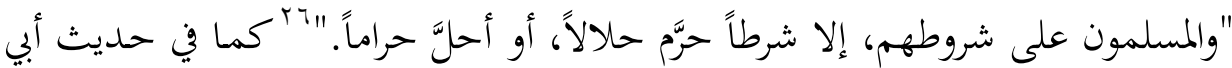
هريرة المشهور.

وتأسيسـاً على ذلـك، فقـــ "اعتـبر فقهـاء السياسـة أنَّ التحـولات السياسـية التي

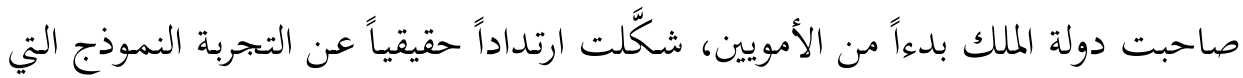

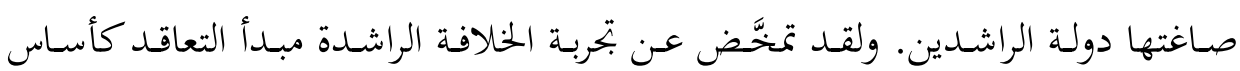

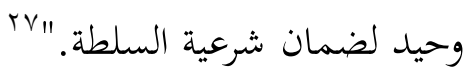

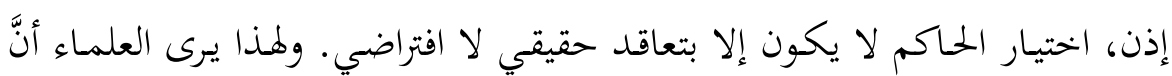

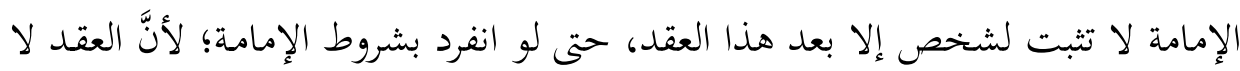

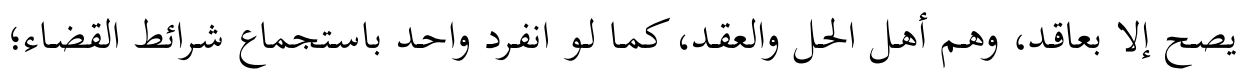

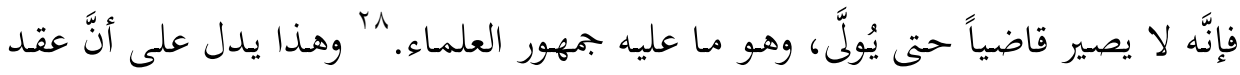

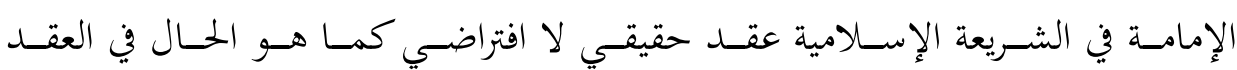

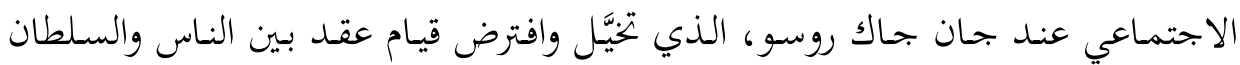

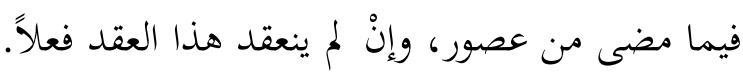

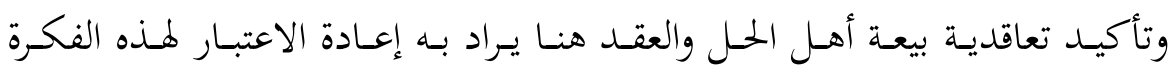

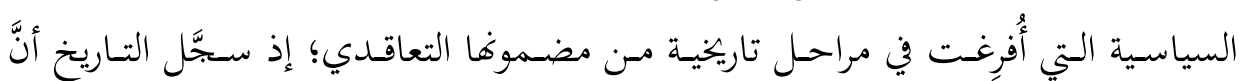

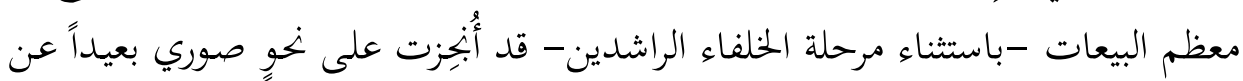

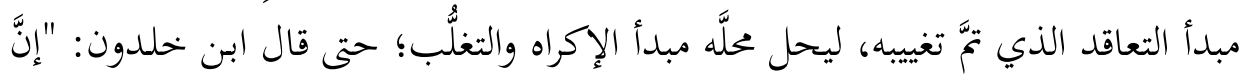

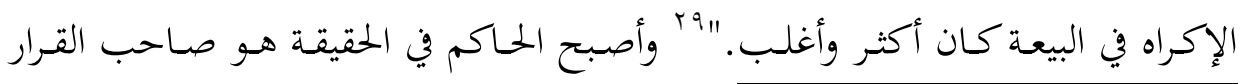

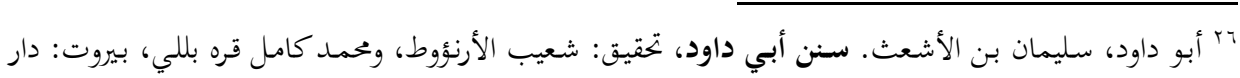

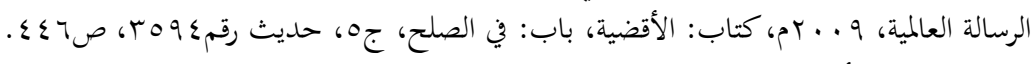

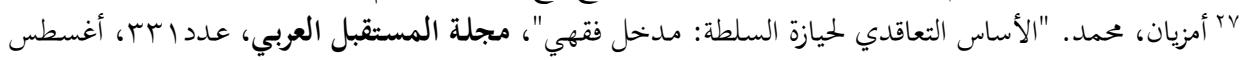

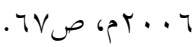




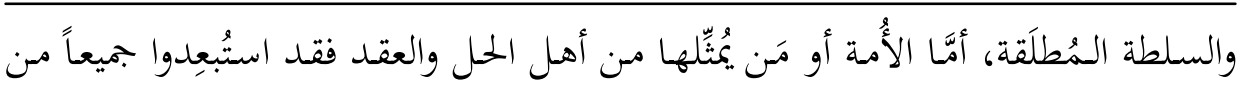

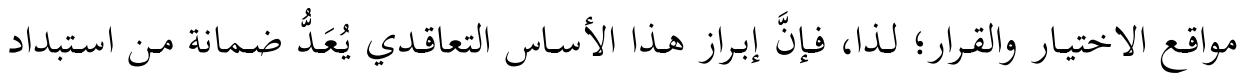

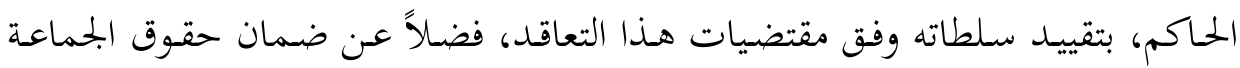
ودورهـا في الفعـل الاجتمـاعي والسياسي والإنكار على السـلطة ومراقبتها، وإعـادة بنـاء

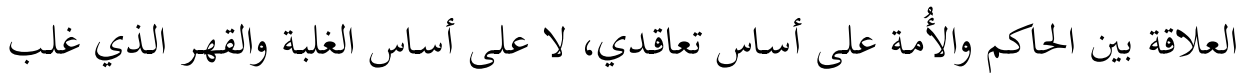
على التنظير الفقهي السياسي. والحقيقـة أنَّ شرعية السـلطة السياسية في الفكر السياسي الإسـلامي تتأسَّس أصلاً

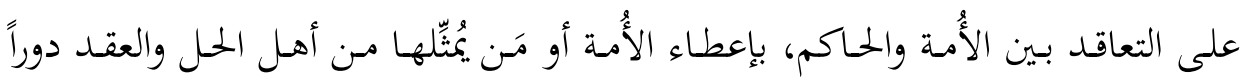

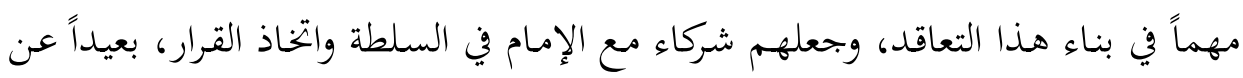
كل المقولات الثيوقراطية التي بندها في بعض تراثنا السياسي الإسلامي، والتي تمنح الحاكم

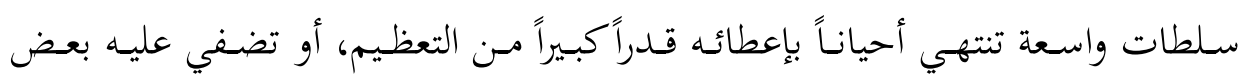

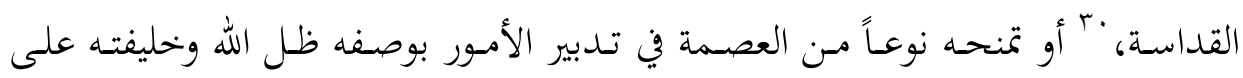
الأرض.

فالتعاقـد إذن طريق لانعقـاد الإمامـة ومُنشِـئ لهـا، وهـو أيضـاً سبيل لتحقيق مشـاركة

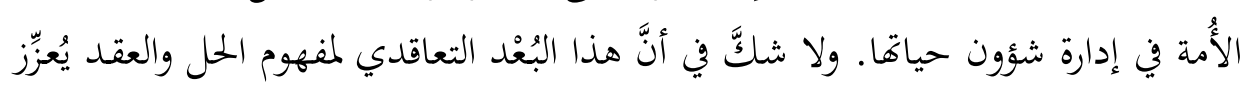

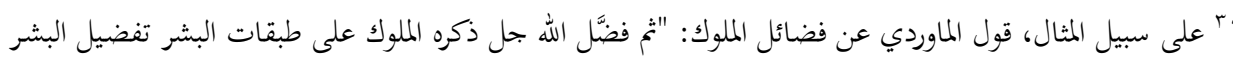

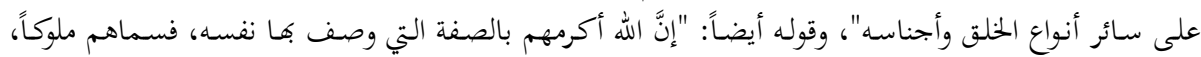

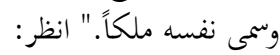

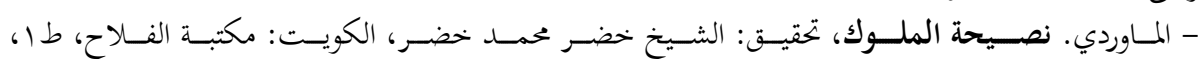

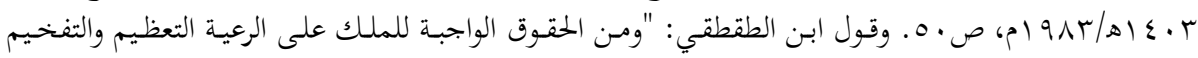

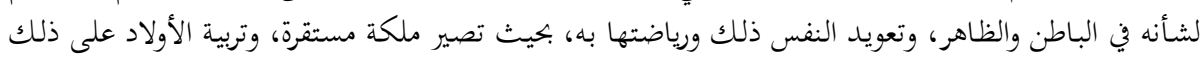

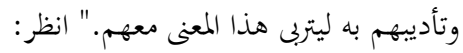
- ابن الطقطقي، محمد بـن علي. الفخـري في الآداب السـلطانية والـدول الإسـلامية، بيروت: دار صـادر، صזr. وقول الجاحظ: "وأولى الأمور بأخلاق الملك، إنْ أمكنه التفرد بالماء والهواء أنْ لا يُشرك فيهما أحداً؛ فإِنَّ البهاء والعزة

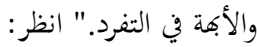

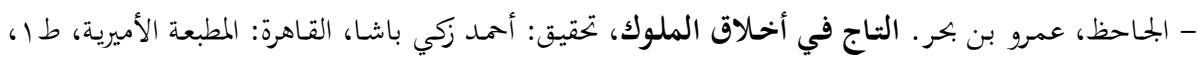

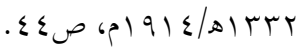




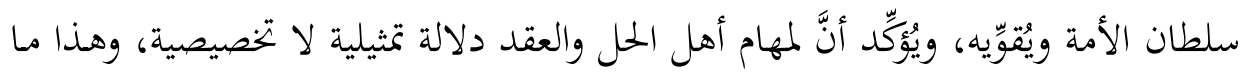

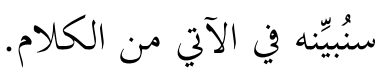

\section{r. أهل الحل والعقد وسلطان الأُمة:}

الأُمة هي صاحبة السلطان في إدارة شؤوفا، وهو ما يبدو من دلالة الخطاب القرآين

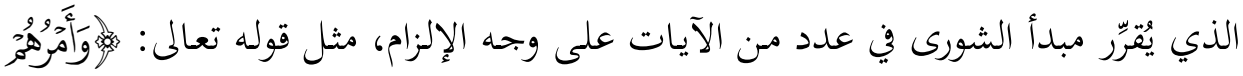

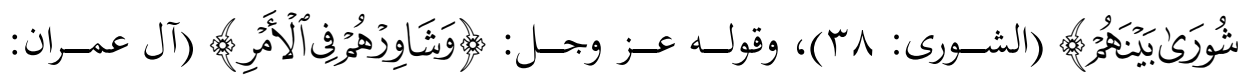

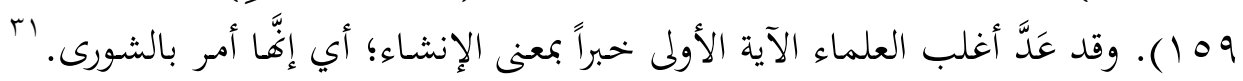

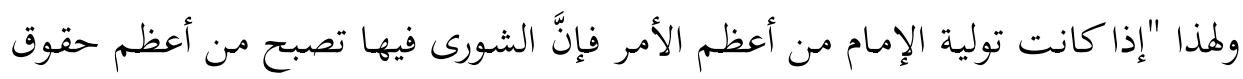

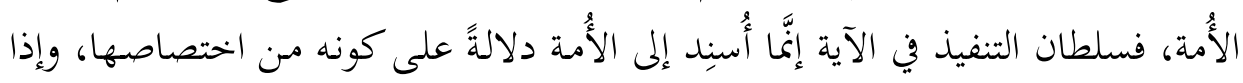

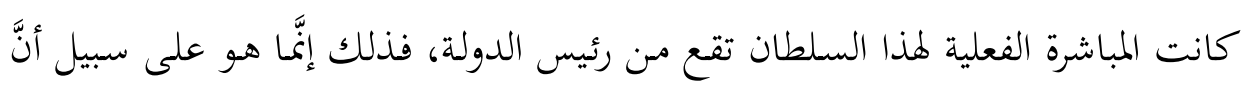

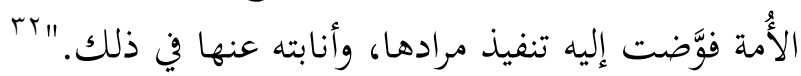

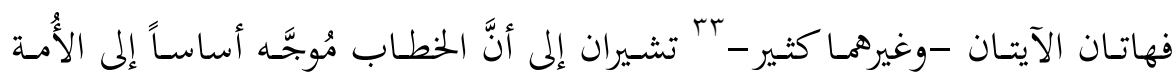

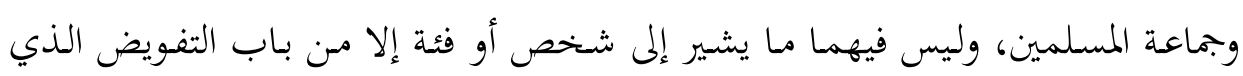

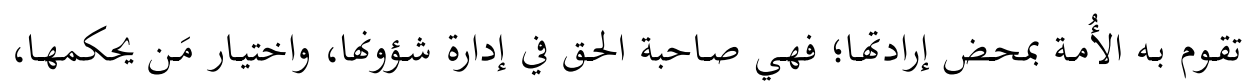

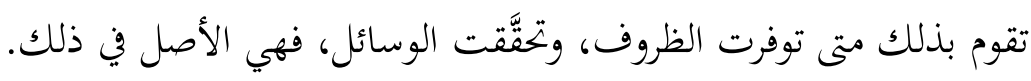
وتحفل كتب السُنْة بالعديد من النماذج التي تُعبِّر عن حرص رسول الله

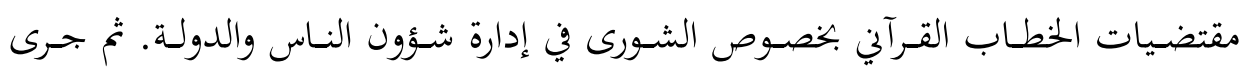

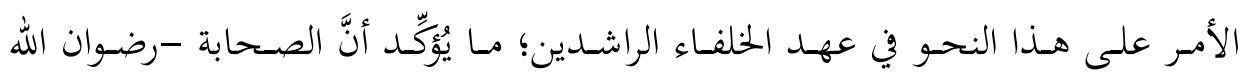
ابrاطياط، عبد العزيز. وأمرهم شورى بينهم، عمّان: جامعة أهل البيت، الجممع الملكي لبحوث الحضارة الإسلامية،

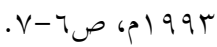

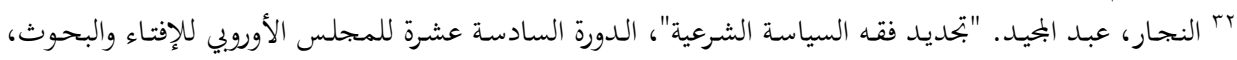

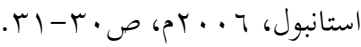

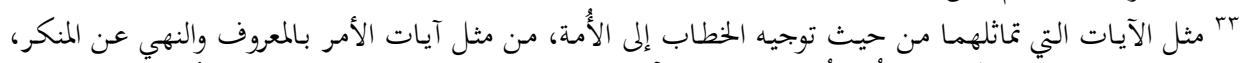

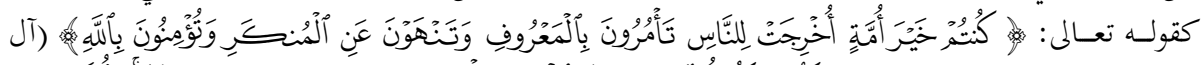

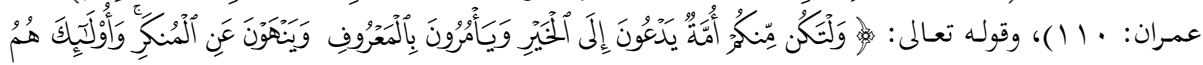


عليهم - لم يغب عنهم، وهـم يباشرون اختيار مَن يهكمهم، مفهوم الشورى الذي تربوا

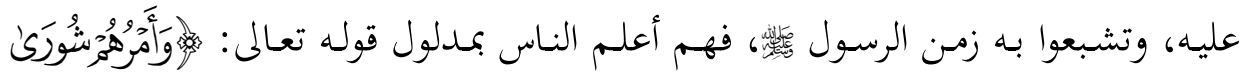

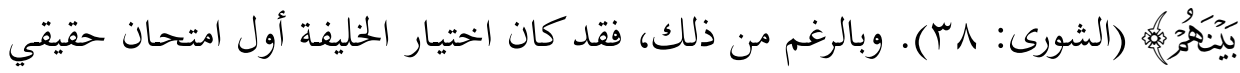
لهم في تمثُّل قيمة الشورى وترسيخها. صحيح أنَّ ذلك تمَّ بقدر من التحاور والتشاور، بيد

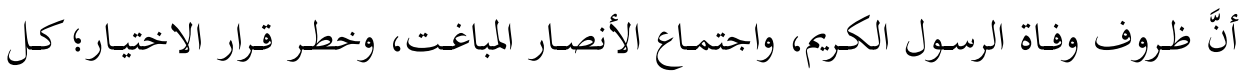
ذلك أوجب عليهم اختيار الخليفة بصورة سريعة مفاجئة، ما أنذر -لا قدَّر اللهـ- بانقسام

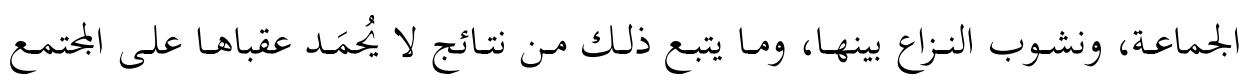
الإسلامي آنذاك؛ لذا بادر الصحابة إلى تصحيح هذا المسار بتوسيع دائرة الشورى بين

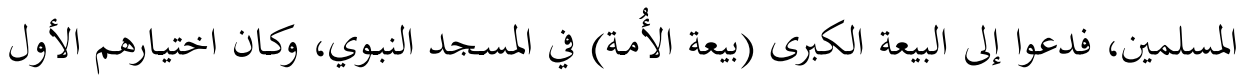

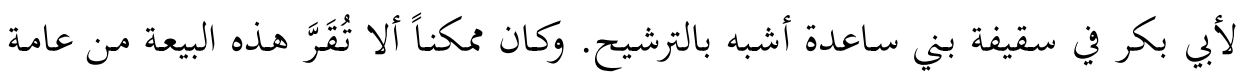
المسلمين، لولا أنَّ المُبايَع هو أبو بكر الصديق، ولذلك قال عمر بن الخطاب في شأنه:

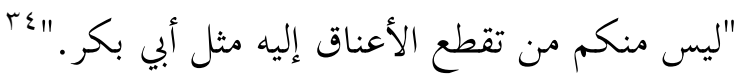

وقد علَّق الإمام ابن تيمية على اختيار أبي بكر إماماً للمسلمين تعليقـاً بيَّن فيه أنَّ

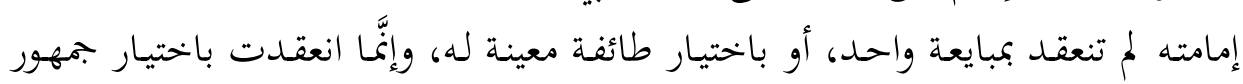

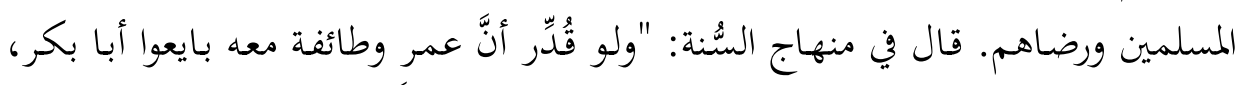

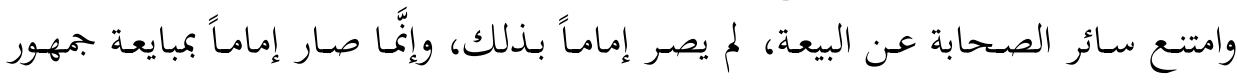

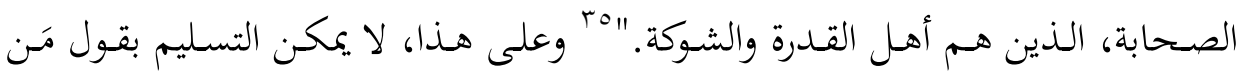

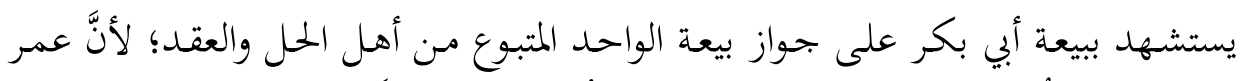

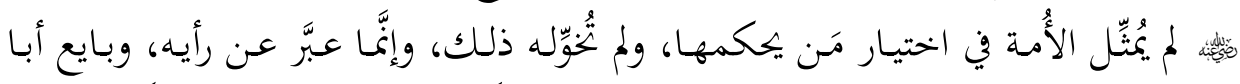

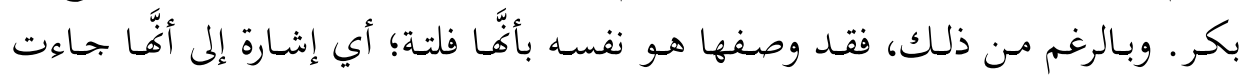

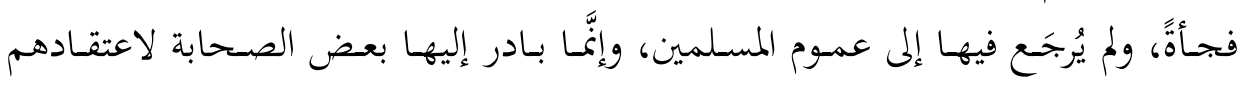
بأحقية أبي بكر بالخافلاف، وخشية أيِّ انفلات بسبب الفجائية في الوضع الجديد، حيث

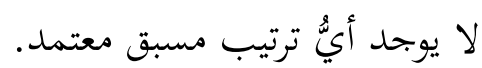

צُ"البخاري، الجامع الصحيح، مرجع سابق، كتاب: أصحاب البي، باب: قصة البيعة، جه، حديث رقم. .rV،

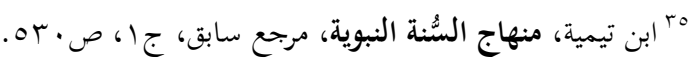


غير أنَّ التنظير السياسي والممارسة السياسية لم يبقيا وفيين لهذا المبدأ (سلطة الأُمة)؛

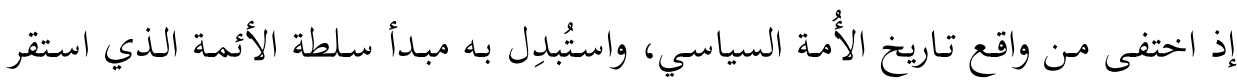

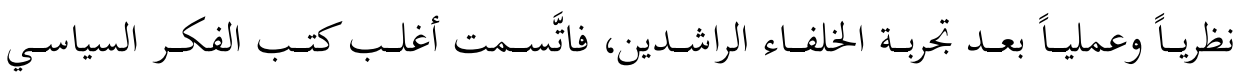

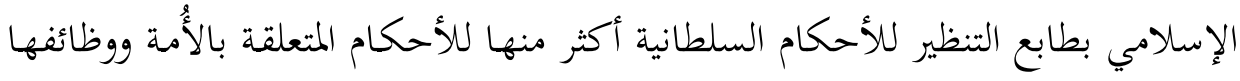

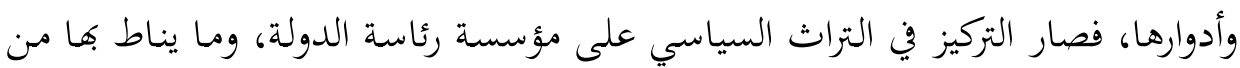

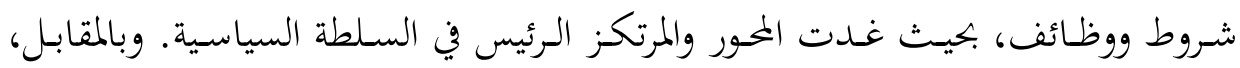

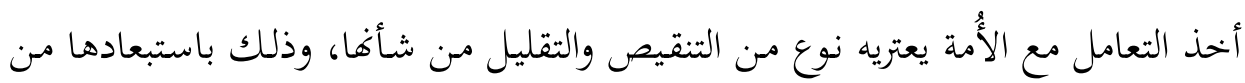

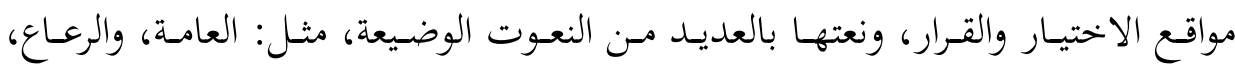

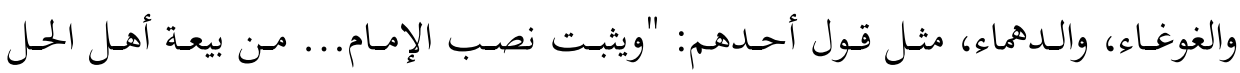

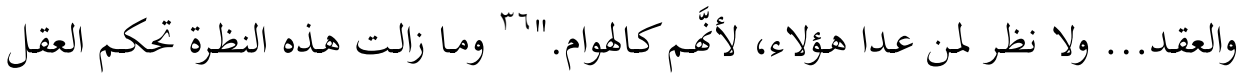
الفقهي حتى الآن.

ولكنَّ الإمكان التـاريخي لم يسمح أحياناً للأُمـة جميعها أنْ تشـارك في اختيـار مَنَ

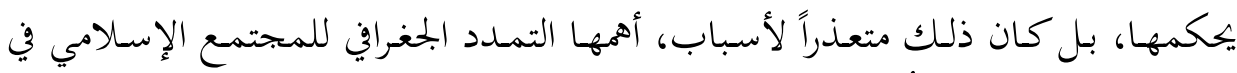

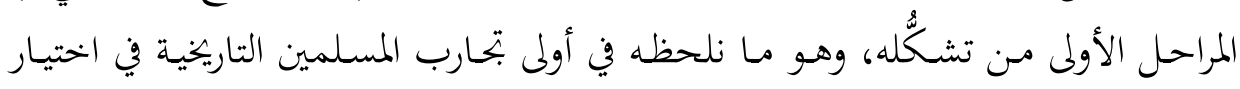

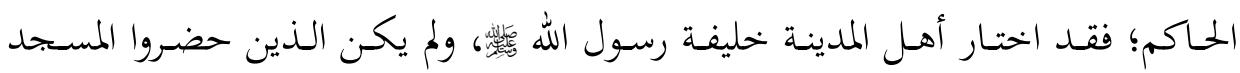

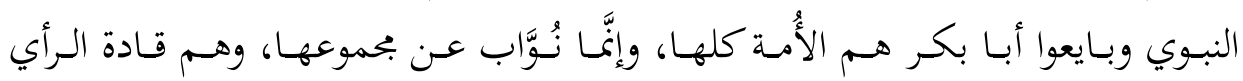

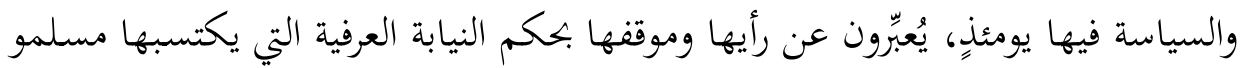

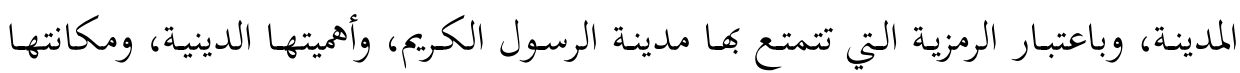

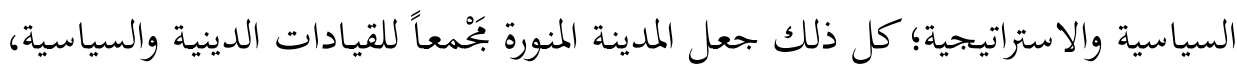
ورمزاً لما يمكن أنْ نسميه قيم الجماعة.

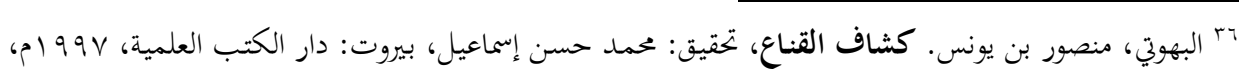

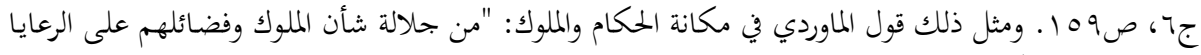

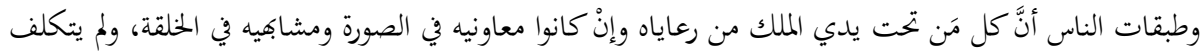

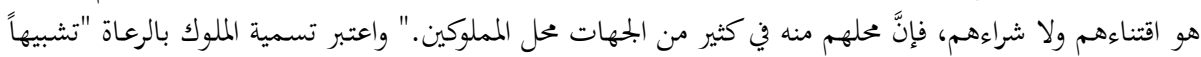

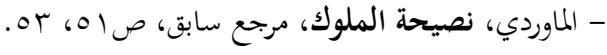




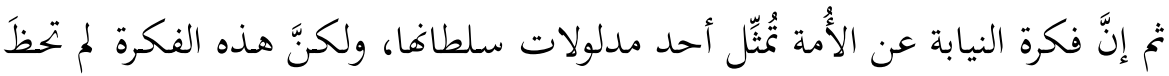

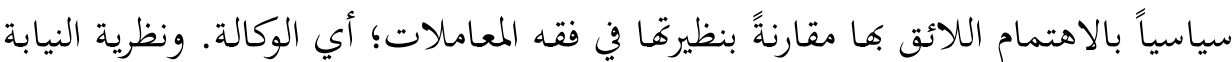

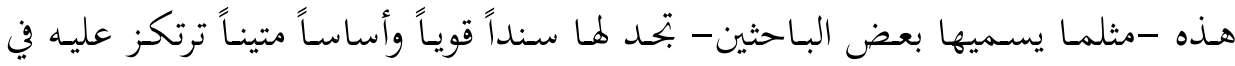

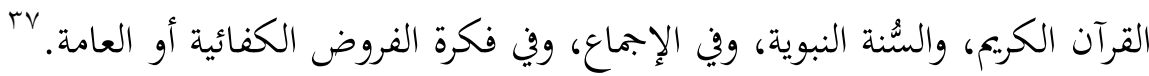
وخلاصة هذا المبحث أنَّ فكرة أهل الحل والعقد هي من الأفكار المبدعة الملهمة التي

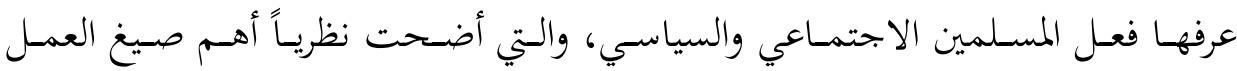

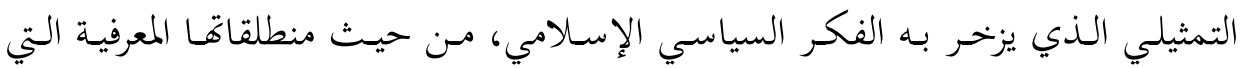

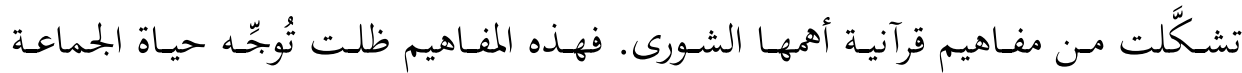

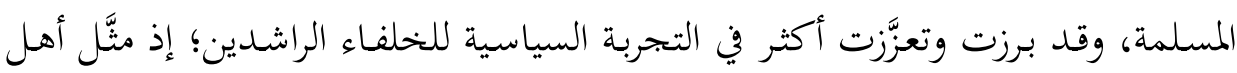

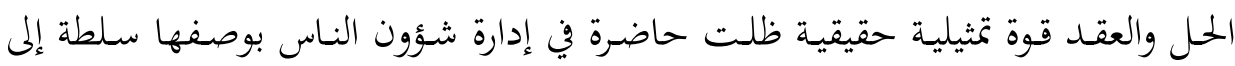
جانب سلطة الحاكم.

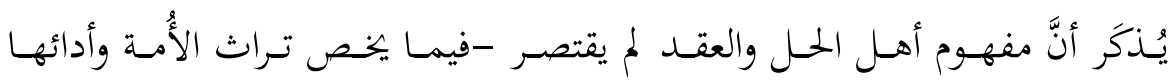

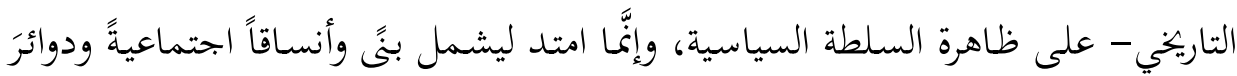

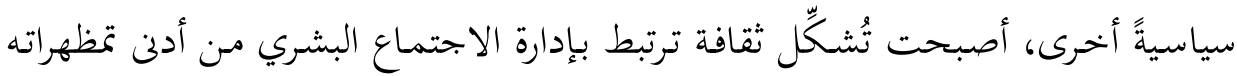

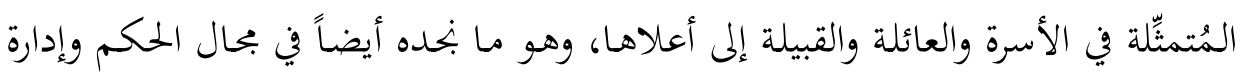
الحياة العامة.

فقي بحال الحكم والسياسة -الذي يُعَدُّ أهم البحالات التي حظيت فيه فكرة أهل

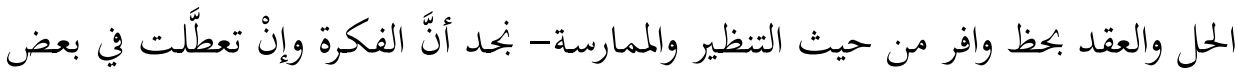

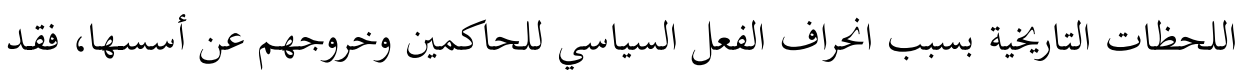

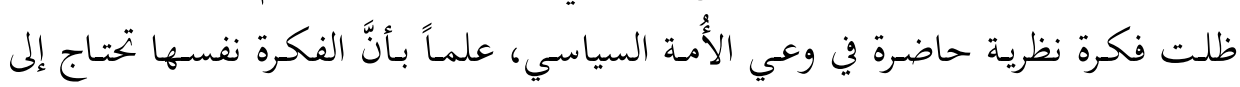

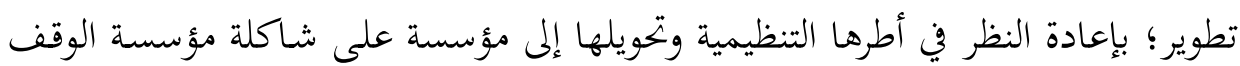

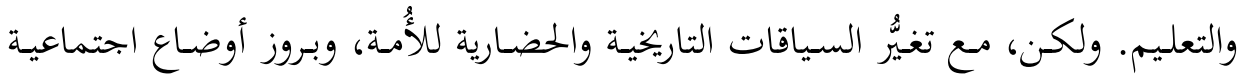

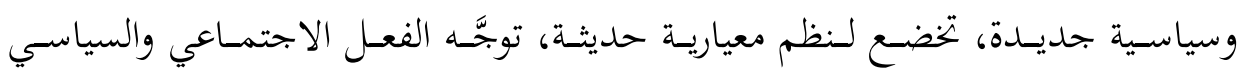

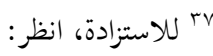
- البياتي، النظام السياسي الإسلامي، مرجع سابق، صلو 1979 


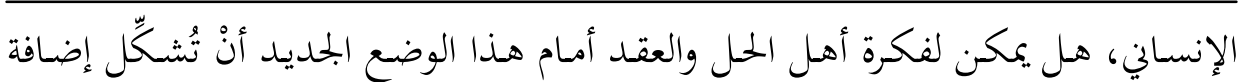

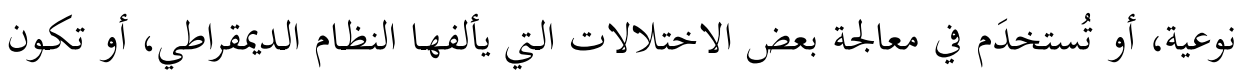

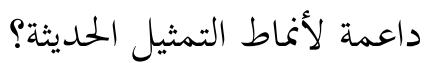

\section{رابعاً: أهل الحل والعقد وإمكانات التطبيق في العصر الحديث}

استقر العمل بمفهوم أهل الحل والعقد في التراث السياسي الإسلامي بوصفه آلية

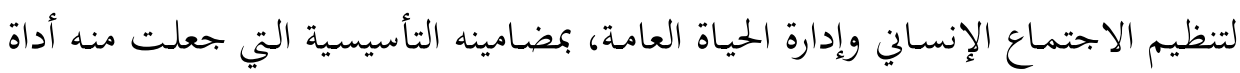

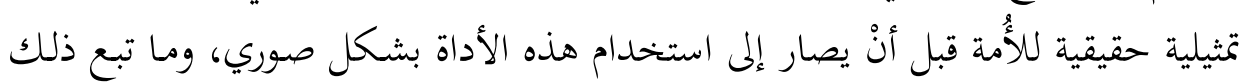

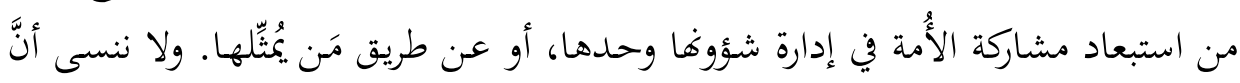

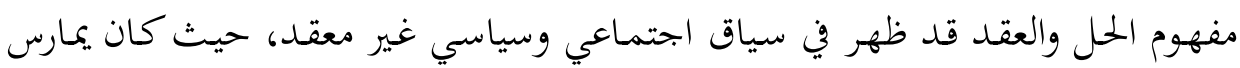

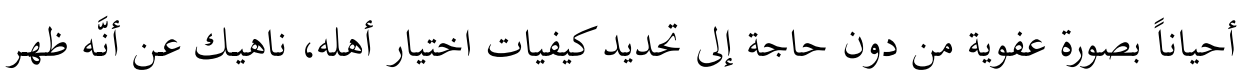
وطُبقق داخل نسق حضاري إسلامي تتبوأ فيه البنى الاجتماعية التقليدية مكانة مهمة.

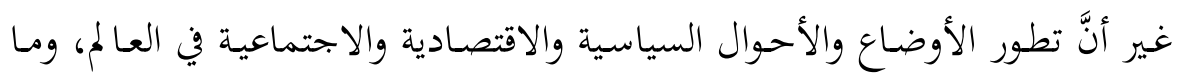

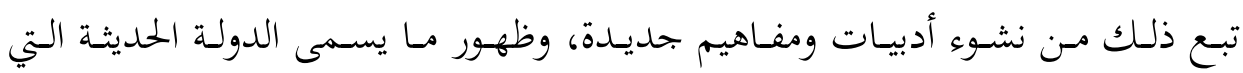

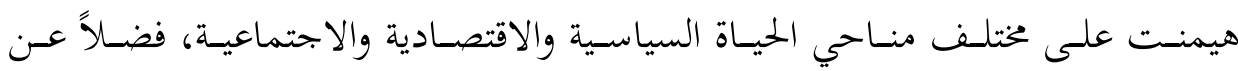

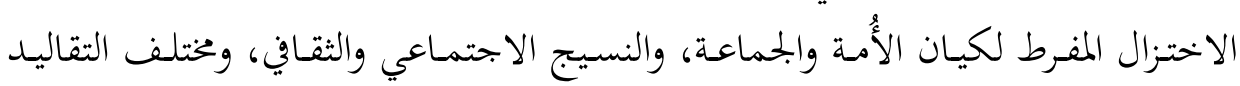

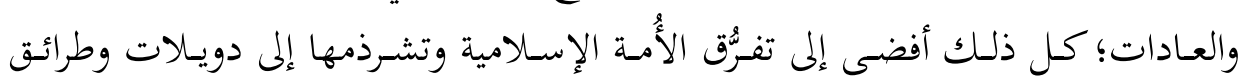

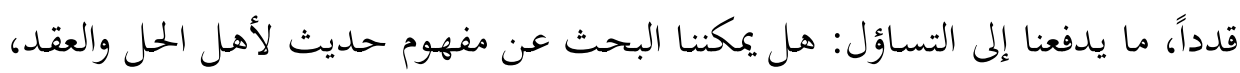

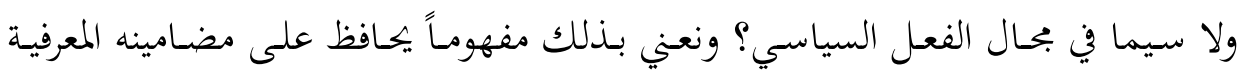

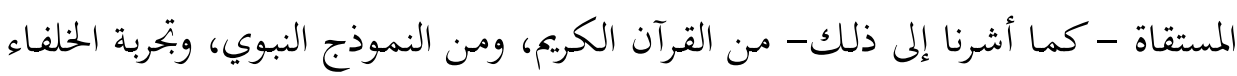

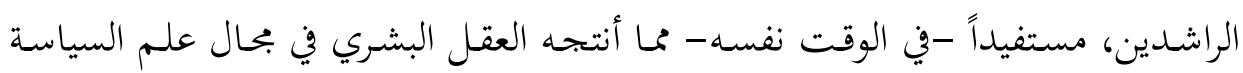

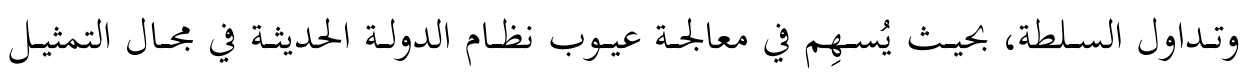
النيابي، وإدارة شؤون الحياة العامة. 
إنَّ طرح هـذا المفهوم الآن لا يهـدف إلى تكييف مضـامينه ومكنوناته في ضوء قيم

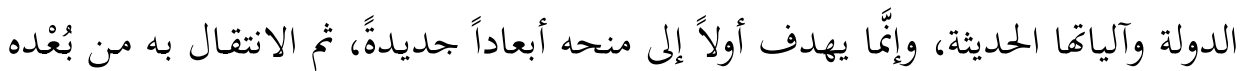

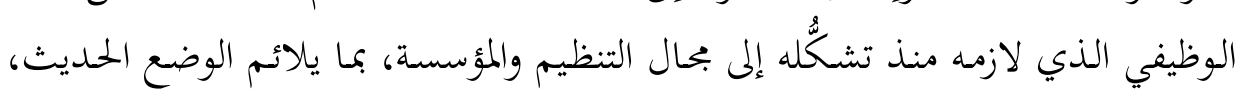

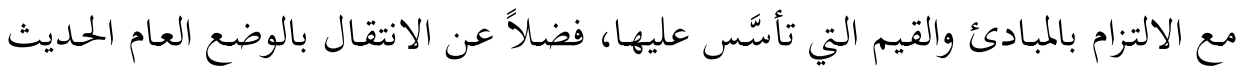
من استبداد الدولة وسطوةا إلى التوازن بين المجتمع والدولة، بحيث يؤدي استلهام الفكرة

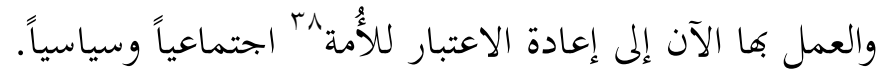

سنعقد في هذا المبحث مقارنة لجماعة الحل والعقد بما تطرحه نظرية النظم السياسية

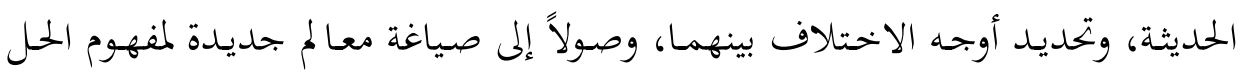
والعقـد، يمـزج بــن الخـبرة التاريخيـة للمفهـوم، والخـبرة الإنسـانية المتراكمـة في بحـال الـنظم

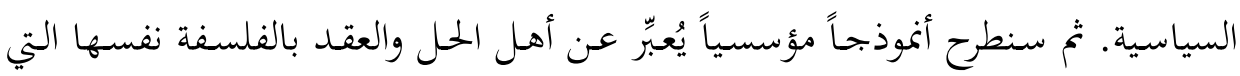

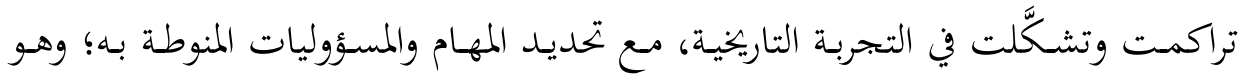
أنموذج يجمع بين أصالة المفهوم، وما أنتجه العقل البشري.

\section{ا ـ أهل الحل والعقد والنظم السياسية الحديثة:}

تُعَدُُّ النظم السياسية الحديثة أحسد منتجات الدولة الحديثة التي نشأت بداية القرن السادس عشر، والتي ظهرت إثر تحولات اجتماعية واقتصادية وسياسية عرفتها أوروبا، وما

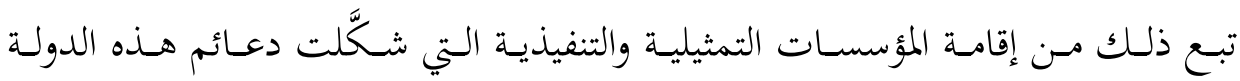
وأسسها. وقد ارتبط مفهوم الدولة الحديثة في سياقها الأوروبي بفصل ما هو سياسي عن إستي كل ما له علاقة بالدين أو القيم، وذلك بتحييد الكنيسة وإقصائها سياسياً. وفي الواقع، فإنَّ مفهوم الدولة الحديثة يطرح على المسلمين معضلتين أساسيتين لمما

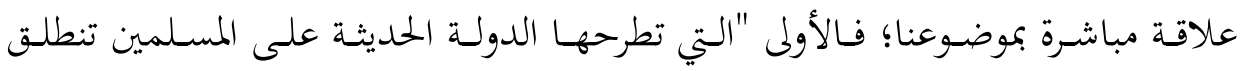

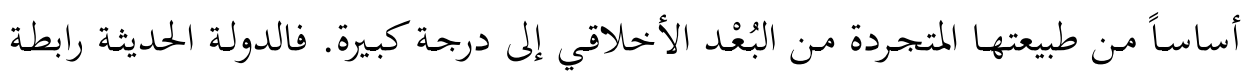

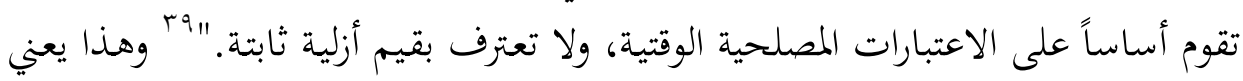




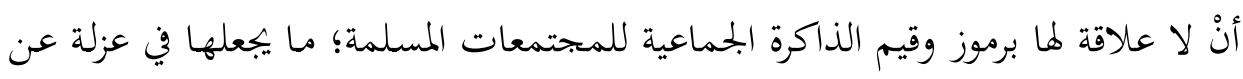

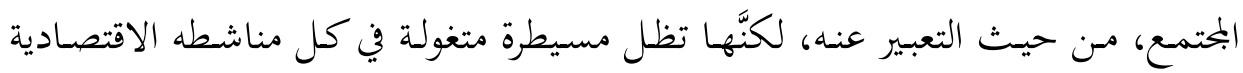

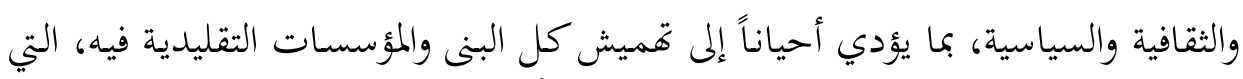

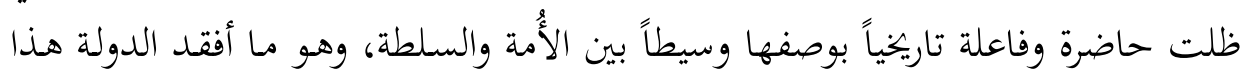

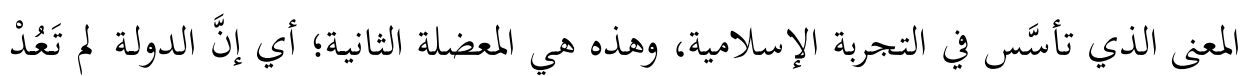

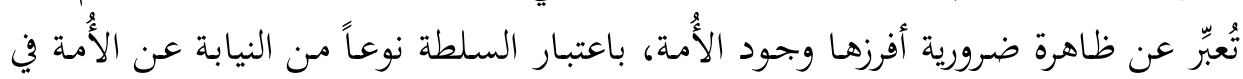
إدارة شؤوها.

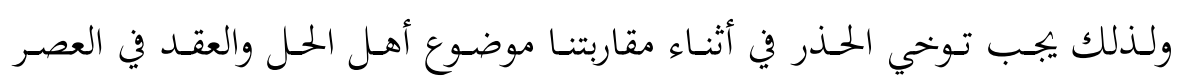

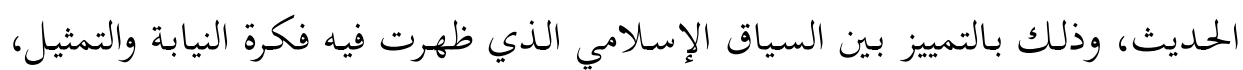

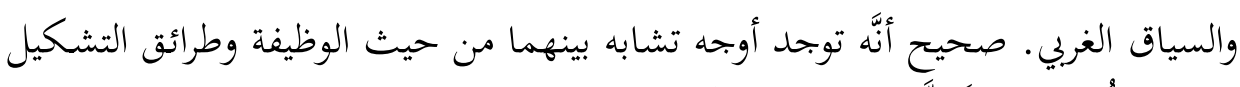

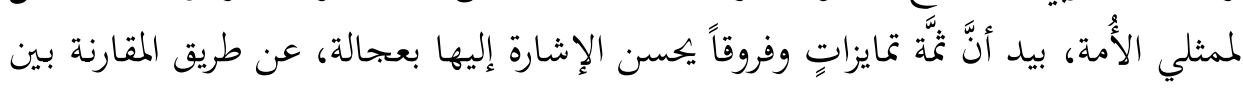

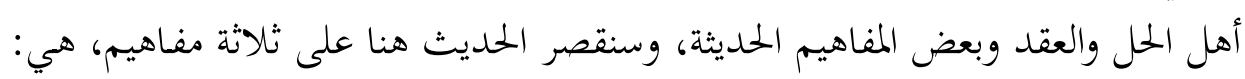

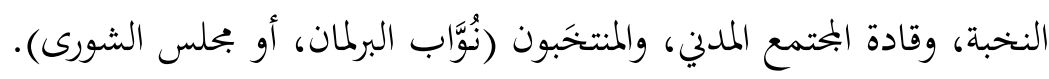

أ. أ. النخبة:

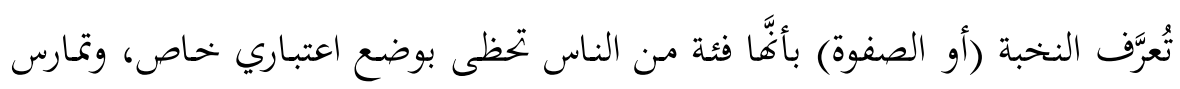

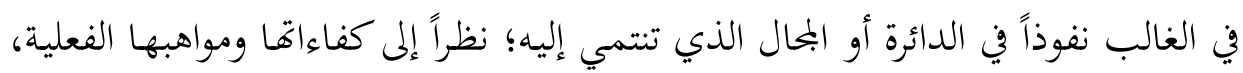

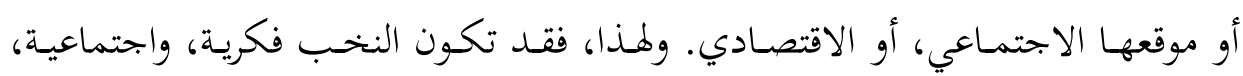

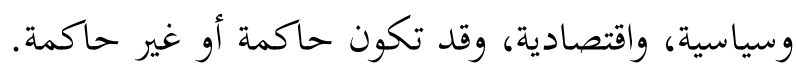

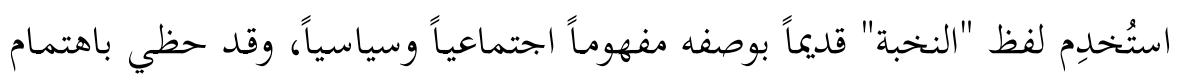

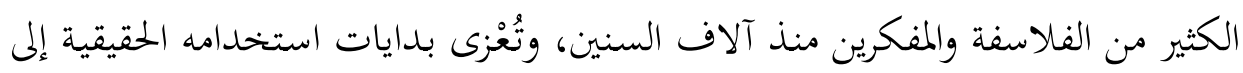

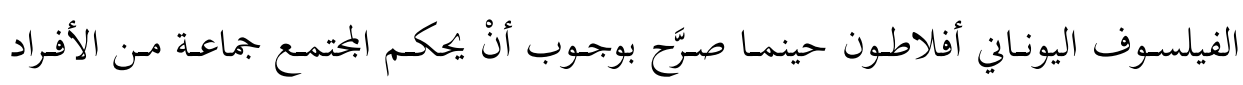

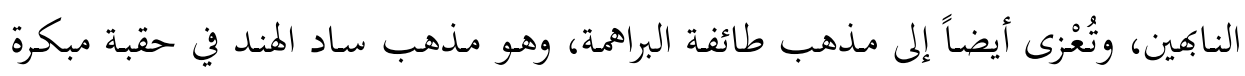

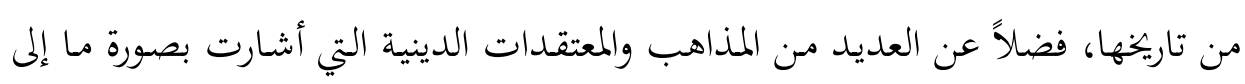


وفكـرة النخبــة في المحال السياسـي تنبع مـن النقاشـات التي دارت حسول نظريـات

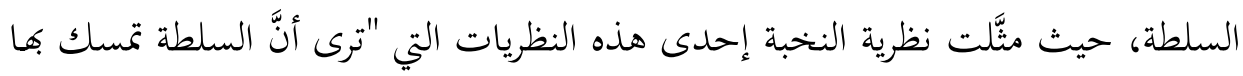

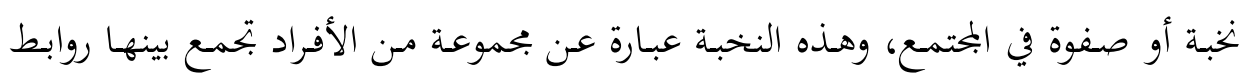

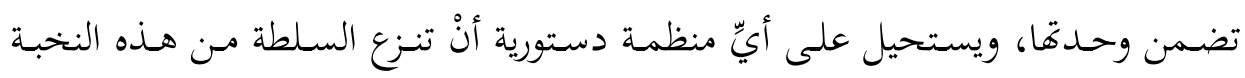

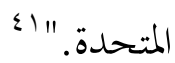

ثم تطور مفهوم النخبة وتعمَّق في علم الاجتماع السياسي في بداية القرن الماضي مع

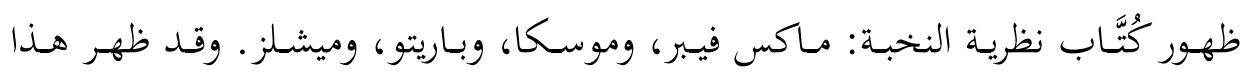

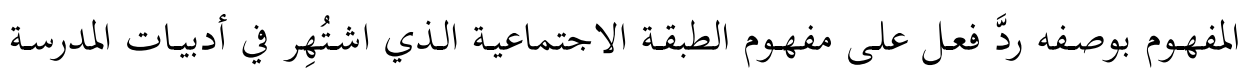

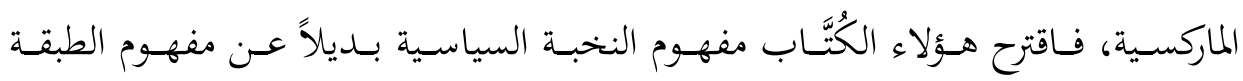

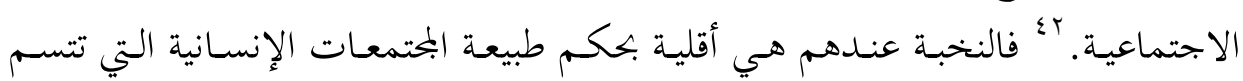

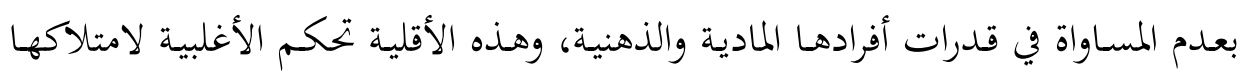

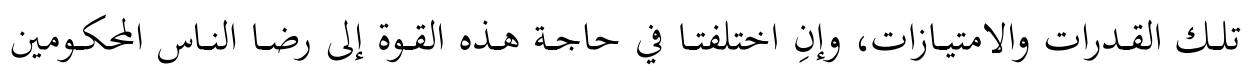

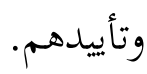

ويرى أصحاب نظرية النخبة أنَّ نظريتهم تقوم على وجود حقيقة اجتماعية تاريخية،

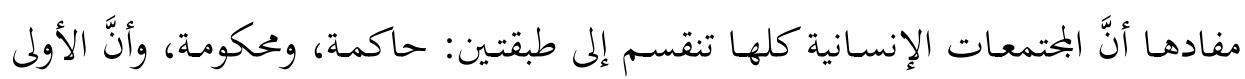

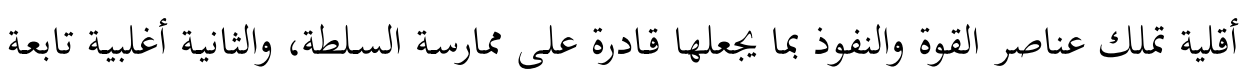

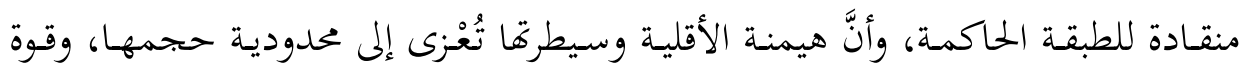

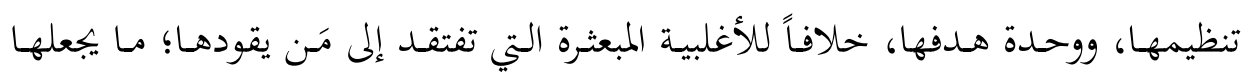
دائماً في حاجة إلى طبقة النخبة.

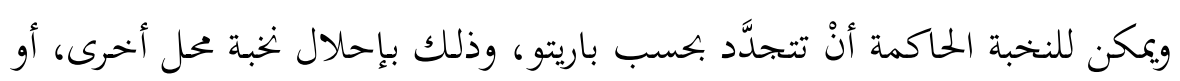

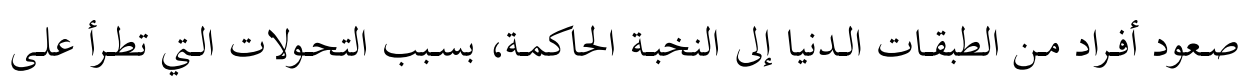
اء الشـرقاوي، سـعاد. السـظم السياســية فـي العـالم المعاصـر، القـاهرة: كليـة الحقـوق، جامعـة القـاهرة، كا

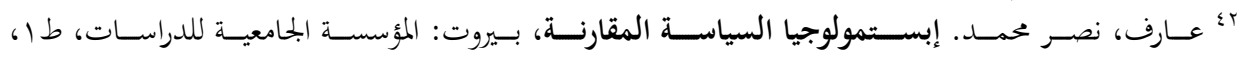

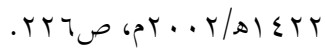


الخصائص النفسية لأعضـاء النخبـة؛ إذ يفقـد هؤلاء بعض الصفات التي كانـت تمنحهم

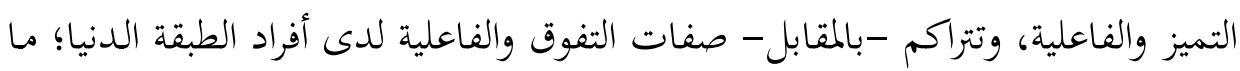

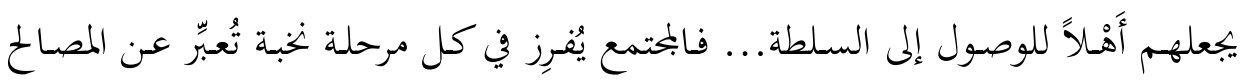
المهيمنة أو الغالبة في المجتمع.

بعـد هـذه العجالـة في تنـاول مسـألة النخبـة، فإنَّهـ يمكـن مقارنتها بفكـرة أهـل الحـل والعقد التي اشتُهِرتِ في الفكر السياسي الإسـلامي، وذلك بـابراز أهـم مـواطن الاتفـاق والاختلاف بينهما. أمَّا أهم مواطن الاتفاق فتتمثَّل في ما يأتي: - التوصيف الاجتماعي والسياسي؛ فأهل الحل والعقد يُمثِّلون نخبة المحتمع سياسياً واجتماعياً، وهـم بحسب الفقه السياسي الإسلامي العلماء والأمراء ورؤساء الجند الذين يتَّصفون بالقدرة على محارسة السلطة، والتأثير في المحتمع وفق معياري القوة والأمانة، وهـم بمنطق علم الاجتماع السياسي يُمثّلّون النخبة أو الصفوة.

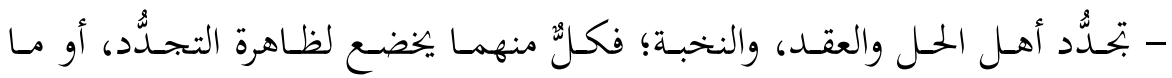
يسمى في نظرية النخبة بـدوران النخبة، وهو إحهلال أفراد محل آخحرين، أو استبدال نخبة

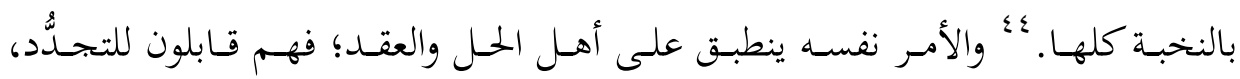

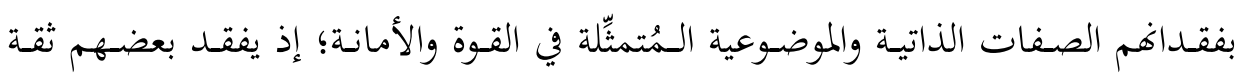
الناس فيهم، ما يُخرِجهم من دائرة أهل الحل والعقد. وأمَّا أهم مواطن الاختلاف فتتمثَّل في ما يأتي: - تحديد مصدر القوة؛ فنظرية النخبة اختلفت في تقدير الأمر بين مُنظرِيها، إذ رأى

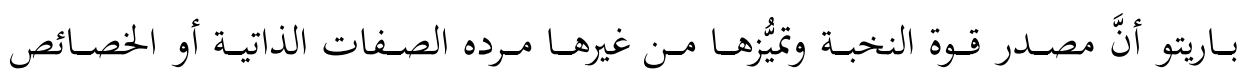
الشخصسية، في حسين أرجعهـا موسـكا وميشـلز إلى عوامـل تنظيميـة، مُسـتبعِدينِ العوامـل بأ أبراش، إبراهيم. علم الاجتماع السياسي: مقاربة إبستمولوجية ودراسة تطبيقية على العالم العربي، عمّان: دار

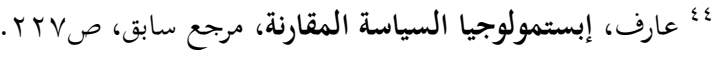




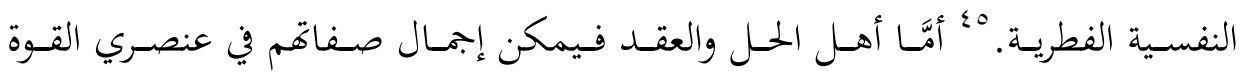
والأمانة، وهي صفات نفسية لا تخلو من صفة موضوعية تتعلق بجانب الشوكة أو القوة

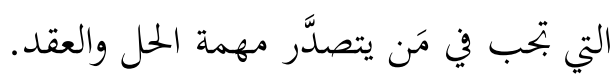

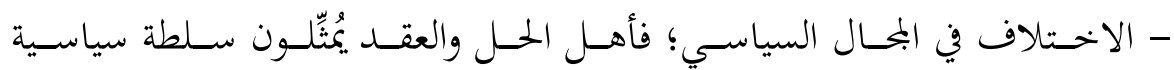

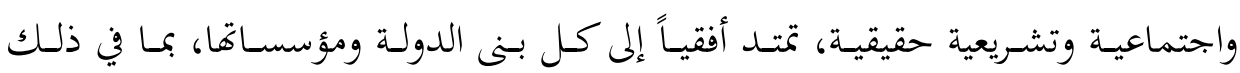

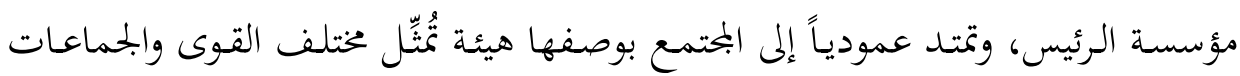

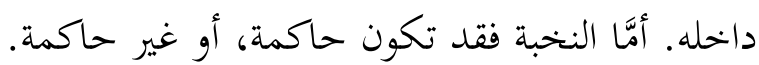
- ثنة الناس؛ إذ يتعيَّن على أهل الحل والعقد أنْ يجوزوا رضا الآخرين عنهم، ليكونها

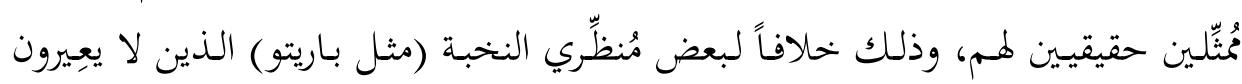

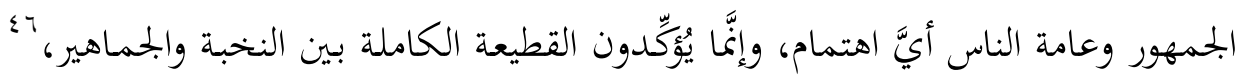

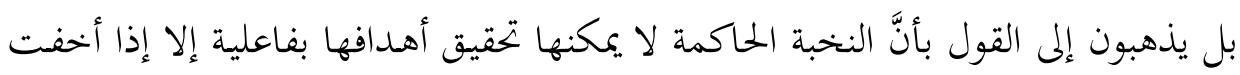

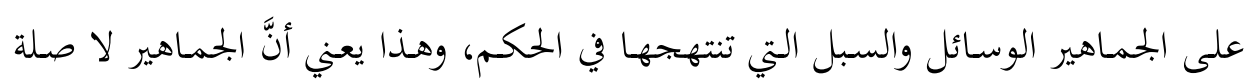

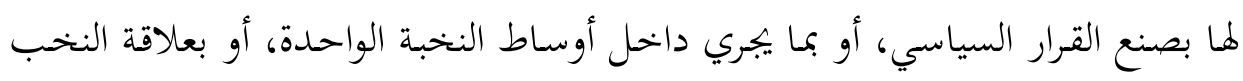
بعضها ببعض، أو بكيفيـة وصول النخـب إلى الحكـم. V؛ والنخبـة بهـا بتعـل ذاتها محوراً ومركزاً، والآخرين تابعين منقادين لا غير، في مشهد يختلف تماماً عمَّا نراه عند أهل الحل والعقد الذين يَعهدون إلى جمهور الناس بالدور الفاعل في ما يخص اختيارهم، ومراقبتهم، ومحاسبتهم.

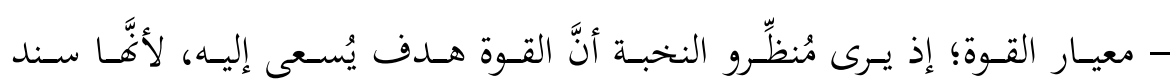

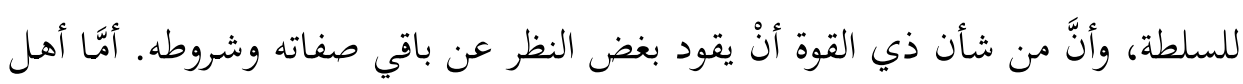

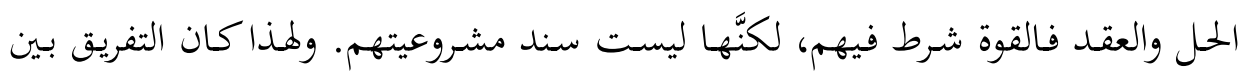
أهل الشوكة الذين لا تتوفر فيهم شروط أهل الحل والعقد، وهؤلاء الذين تتوفر فيهم هذه ه؛ أبراش، علم الاجتماع السياسي: مقاربة إبستمولوجية ودراسة تطبيقية على العالم العبب، مرجع سابق، صلع وما بعدها.

${ }^{46}$ Alberto, Puppo. "Gaetano Mosca et la théorie de la classe politique". Revue Française d'Histoire des Idées Politiques 2, 2005, (n²2).

V أبراش، علم الاجتماع السياسي: مقاربة إبستمولوجية ودراسة تطبيقة على العالم العبب، مرجع سابق، صV \&. 


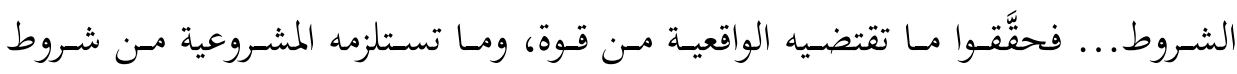

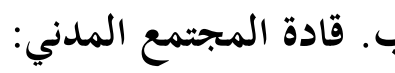

ارتبط مفهوم البحتمع المدني -بوصفه منظومة متكاملة- بالسياق الغربي الحاضن له

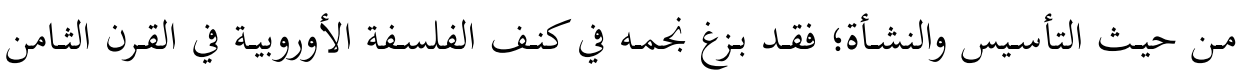

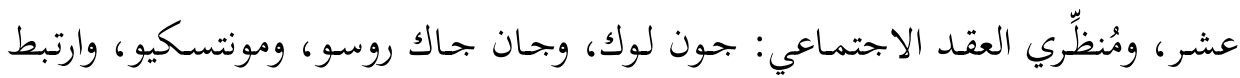

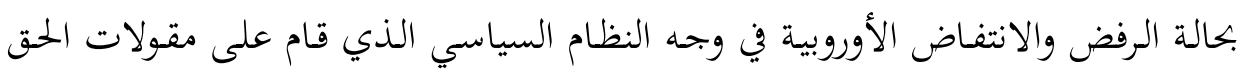

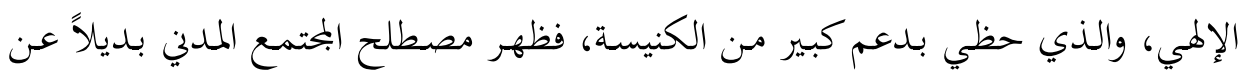
المختمع الديني.

وتُمتِّل مفـاهيم المحتمع المددني ومفرداته جزءءً مـن النظرية السياسية الغربية، ولا سيما

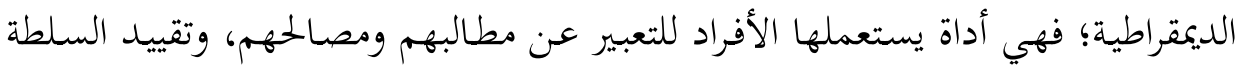

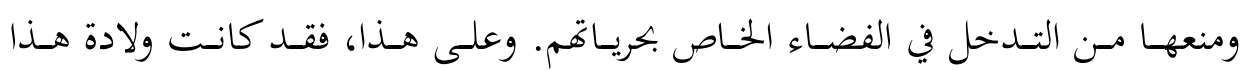

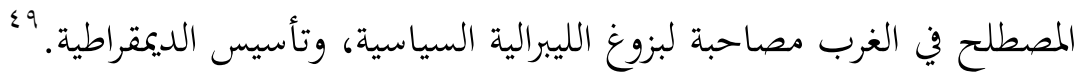

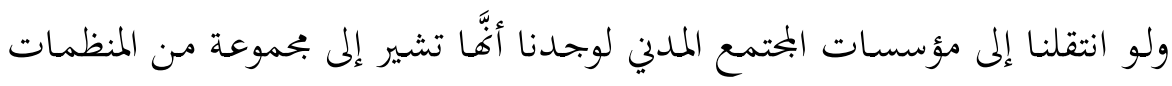

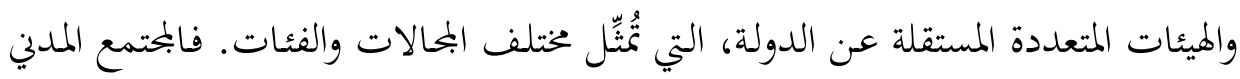

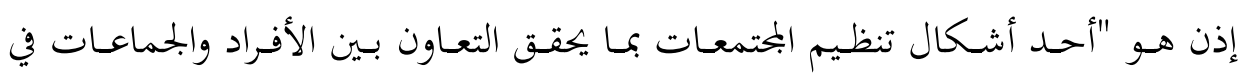

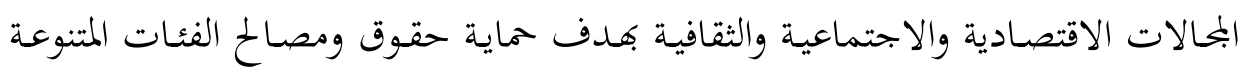

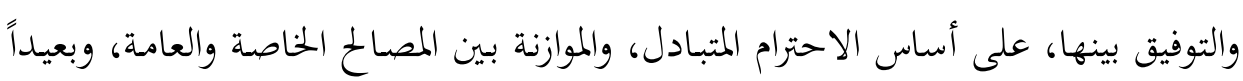

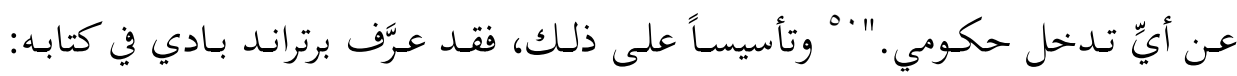

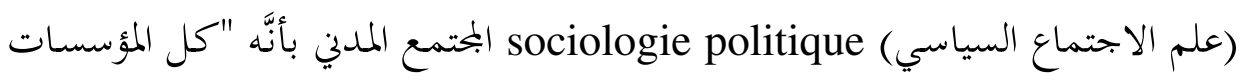

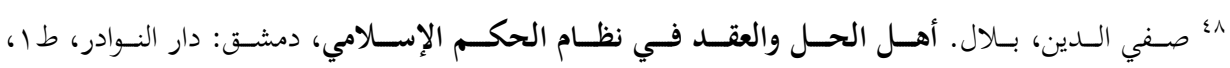

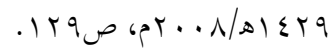

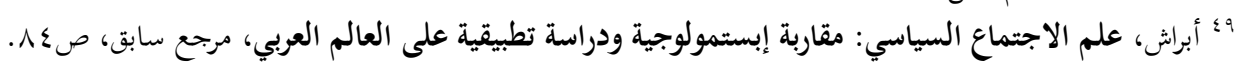

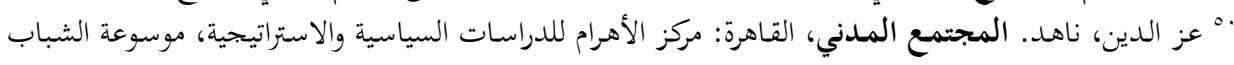


التي تتيح للأفراد التمكٌُ من الخيرات والمنافع العامة دون تدخل أو توسط الدولة." الهُ أمَّا أهم ما يميٍُّز هذه المؤسسات في تشكيلها وتأسيسها فهو عنصر التطوع.

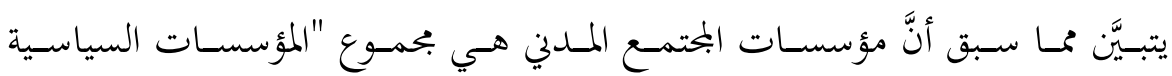

والاقتصادية والاجتماعية والثقافية التي تعمل في ميادينها المختلفة، في استقلال عن سلطة

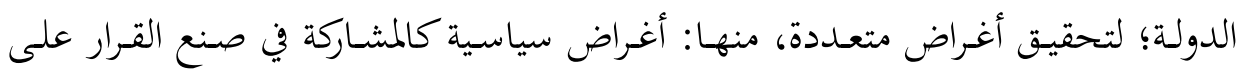
المستوى الوطني والقومي، ومثال ذلك الأحزاب السياسية، ونقابية كالدفاع عن المصالح الاقتصـادية لأعضـاء النقابـة، ومنهـا أغـراض مهنيـة كمـا هـو الحسال في النقابـات للارتفـاع

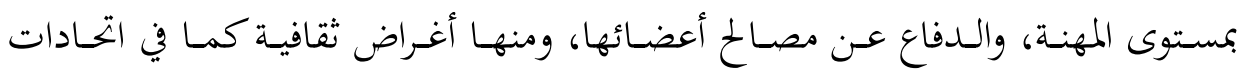
الكُتَّاب والمثقفين التي تمدف إلى نشر الوعي الثقافي والحضاري، وفتاً لابتحاهـات أعضاء كل جمعية، ومنها أغراض اجتماعية للإسهام في العمل الاجتماعي لتحقيق التنمية. وبناءً على هذا التعريف، يمكن تحديد المحتمع المدني بثلاثة مكوِّات، هي: الأحزاب

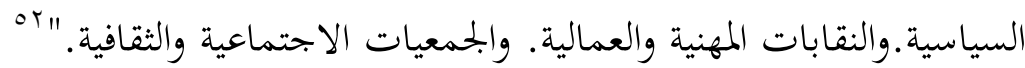

وعلى هـذا، فـإنَّ قـادة المحتمـع المــدي هـم المسـؤولون عـن الجماعـات السياسـية، والاقتصادية، والاجتماعية، والثقافية، والمهنية، والحقوقية المختلفة؛ أي هم قادة نسيج كبير من البحتمع ينتظم في تكوينات منظمة مستقلة عن الدولة. فهل يمكن أنْ يتماهى مفهوم

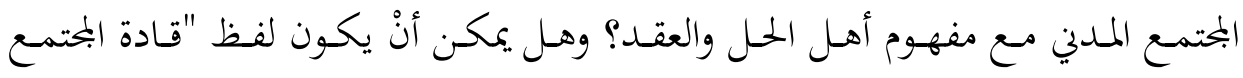

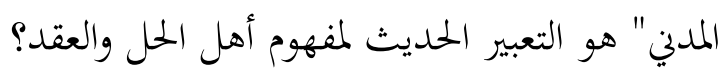

لا شـكَّ في أنَّهَ يوجـد نوع مـن التمـاهي بـين المفهومين في بعض الأبعاد التكوينيـة، لكنَّهما يظلان متمايزين من حيث الوظيفة؛ فهما يلتقيان من حيث التكوين في تمثيلهما تختلف هيئات المحتمع ومؤسساته، لكنَّهما يختلفان في جوانب عدَّة، أبرزها: - نشأة مفهوم أهل الحل والعقد في سياقه الإسلامي؛ ما يعني أنَّه وليد البيئة الذاتية

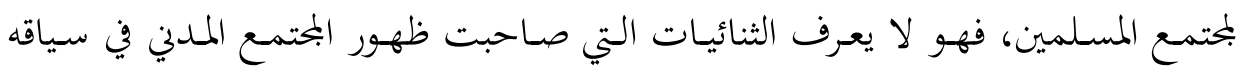

${ }^{51}$ Bertrand , Badie. "Socilogie politique." presses universitaies de France, paris1997, p.105.

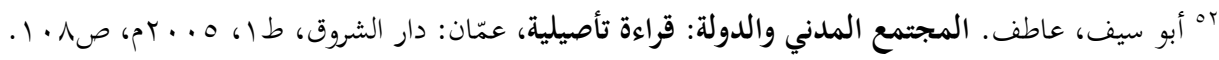




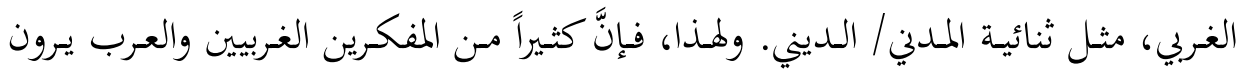

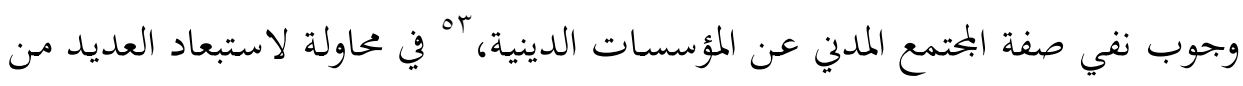
قادة هذه المؤسسات.

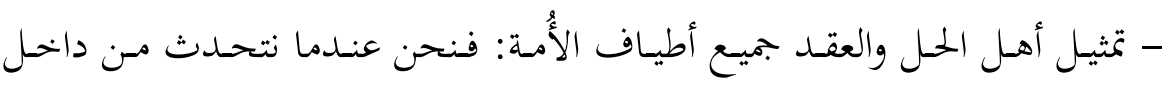

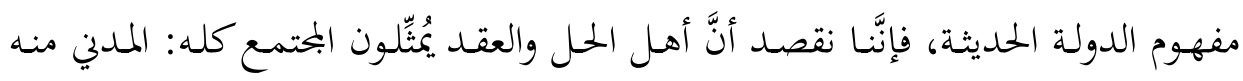

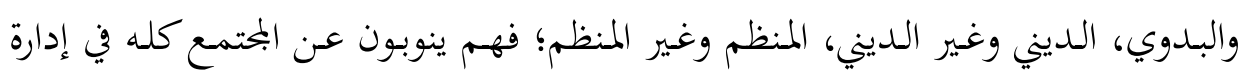

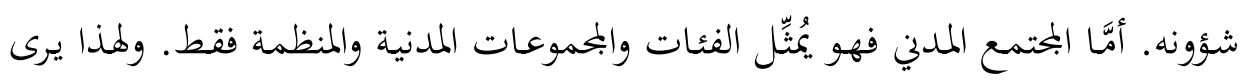

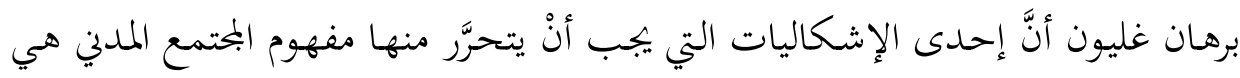

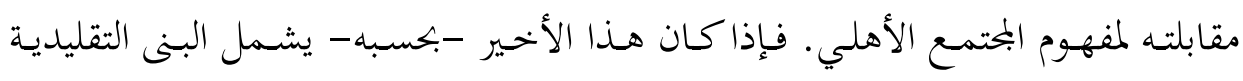

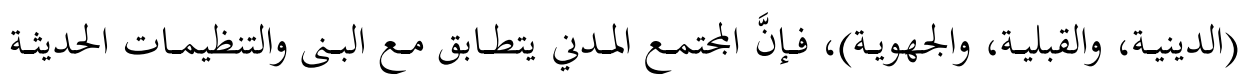

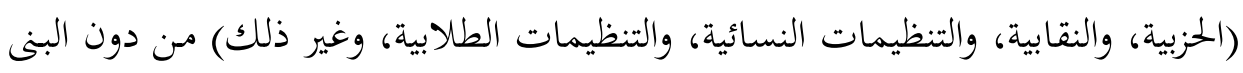

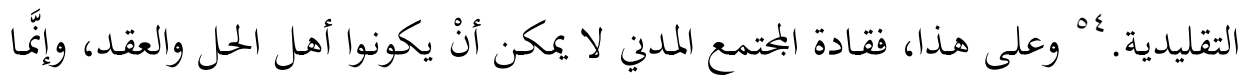
هم جزء منهم.

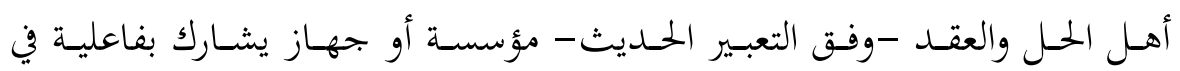

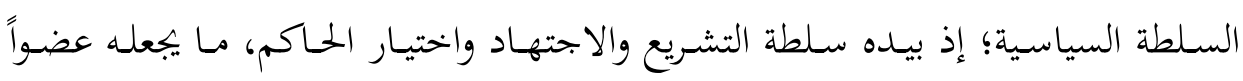

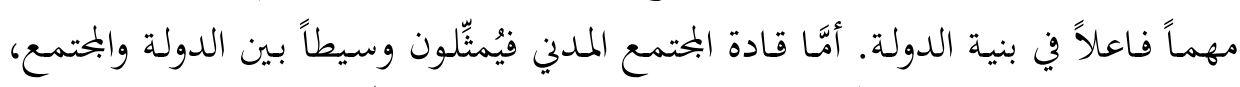

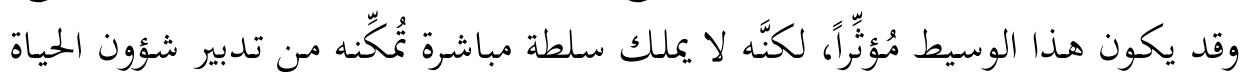

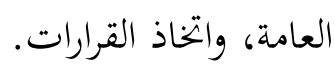

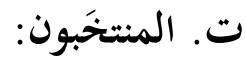

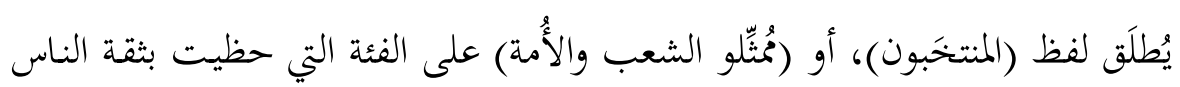

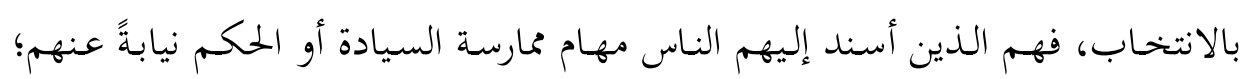

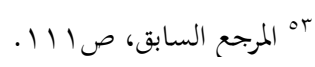
\&ٔ غليون، برهان. المجتمع المدني في الوطن العربي، بيروت: مركز دراسات الوحدة العربية، ب99 ام، صع VT. 


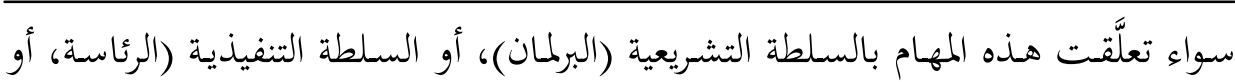
رئاسة الحكومة). والذي يعنينا في هذا المقام هو الفئة الأولى فحسب.

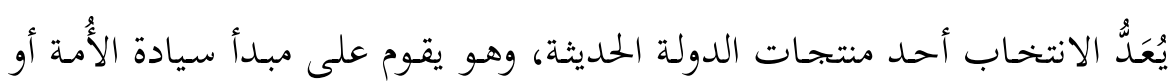
الشعب الـذي ارتبط بالدولـة الديمقراطيـة الحديثة، حيـث تـترجم هـذه السـيادة بالمشـاركة

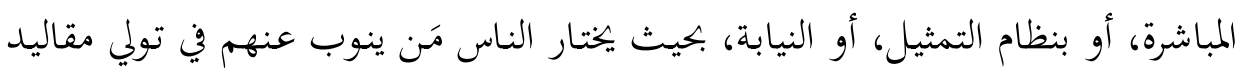

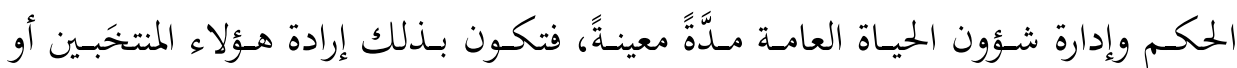

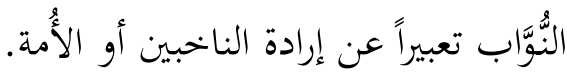

ولـمَّما تعـذّر تطبيق الديمقراطيـة المباشـرة في الدول الكـبـى؛ لاستحالة جمـع المـواطنين كافةً في جمعيـة عامـة، فقــ ظهرت بعض الممارسات الجحيـدة، مثل الديمقراطيـة التمثيليـة

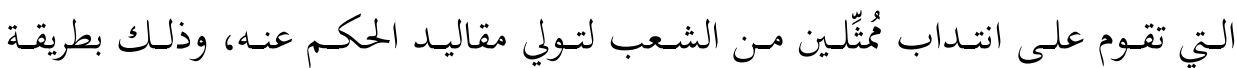

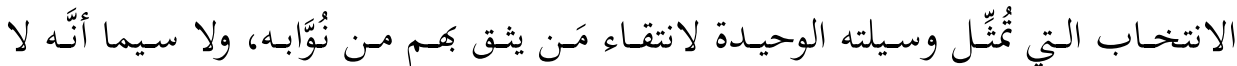
يستطيع محارسة الحكم مباشرةً.

ونظام التمثيل الذي يمارس فيه الناس سلطة اختيار مَن يُمَّتّهم، أو ينوب عنهم في

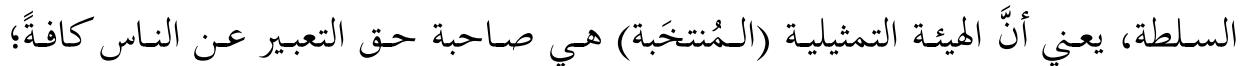

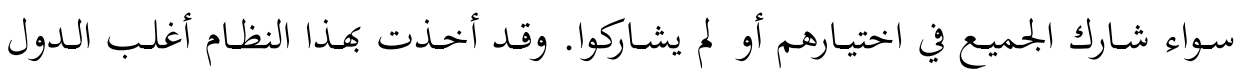

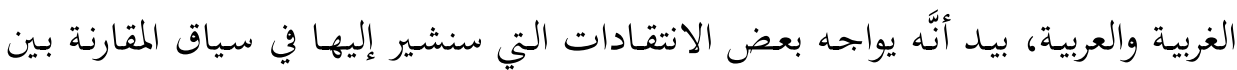
فكرة أهل الحل والعقد وفكرة النيابة أو التمثيل التي يطرحها النظام الديمقراطي الحديث. ويبدو أنَّه توجد ملامح مشتركة بين أهل الحل والعقد وهيئة المنتخَبين (البرلمان) التي تطرحها نظرية التمثيل الديمقراطي، يمكن إجمالها في الآتي: - كـال الفريقين يجظى بالشـرعية السياسية؛ سـواء أكـان ذلك بمقتضى العُرف أم القانون. - - كلا الفريقين ينوب عن الأُمة أو الشعب في التعبير عن إرادته، والحكم باسمه.

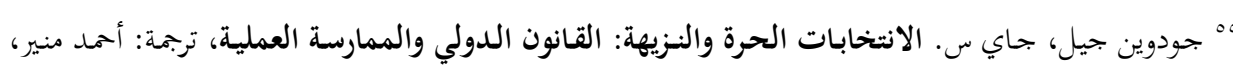

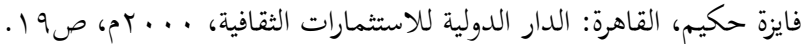




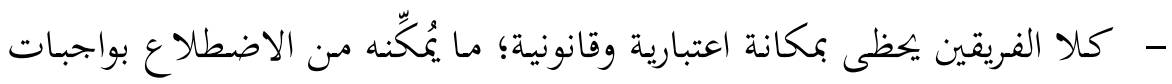

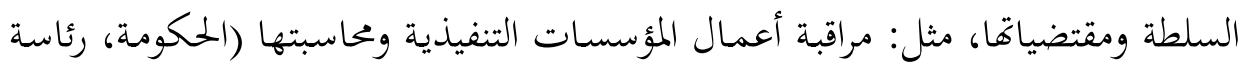

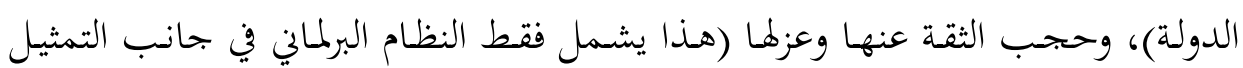
الديمقراطي). وبالمقابل، توجد اختلافات وفروق مفاهيمية وسياسية واجتماعية بينهما، تتمثَّل في

- أكثر بُمثّلي الشعب في النظام الديمقراطي هم نتاج عملية سياسية دعائية يُسبهِم

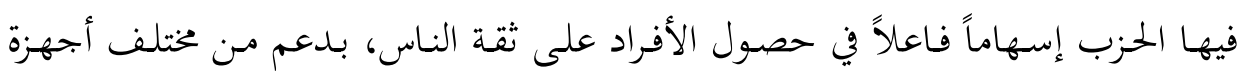

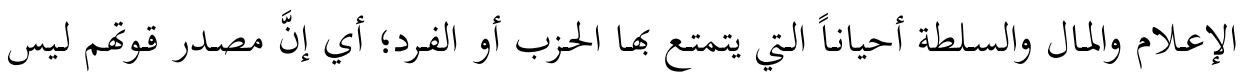

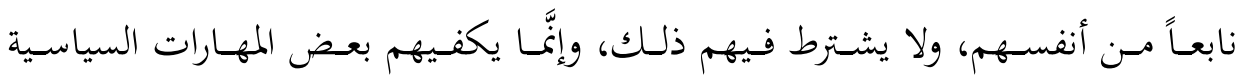

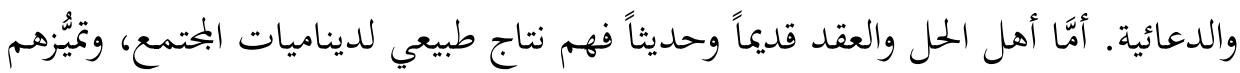

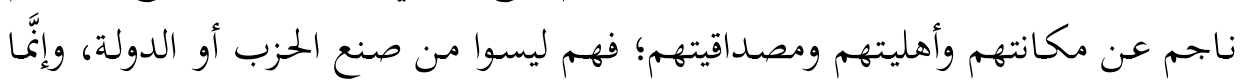

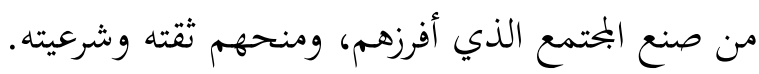

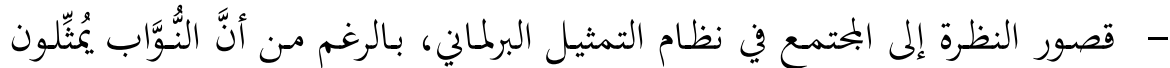

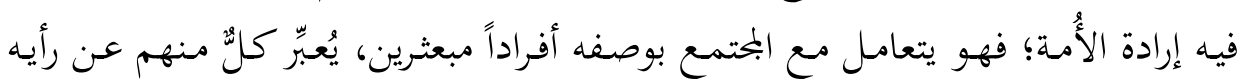

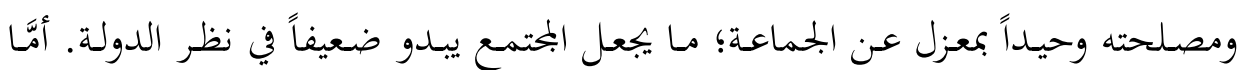

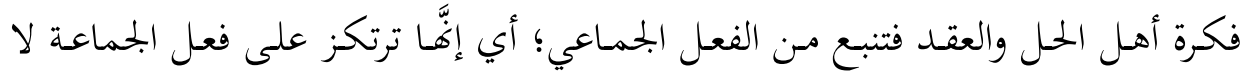

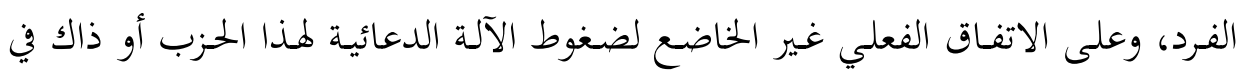

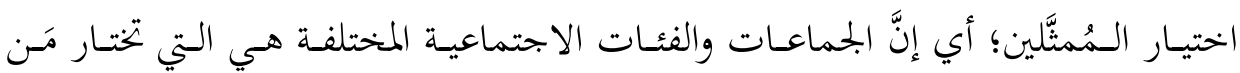

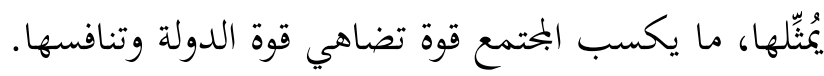

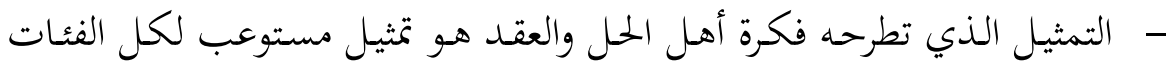

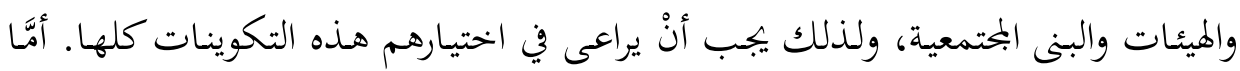

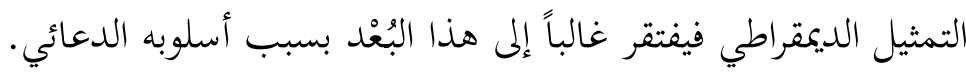

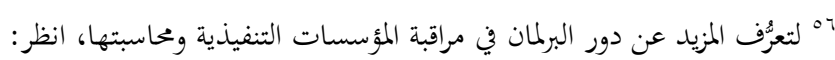

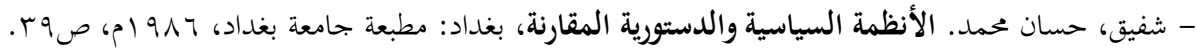




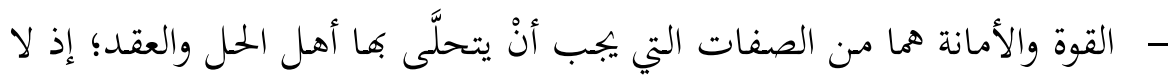

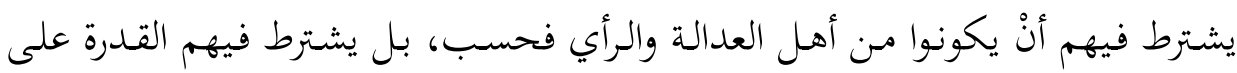

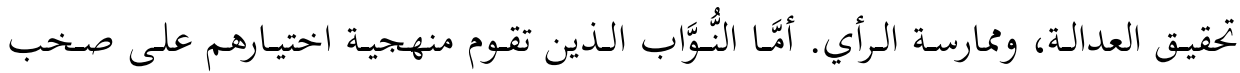

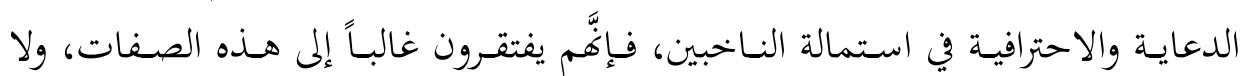

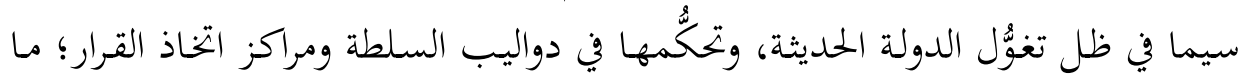

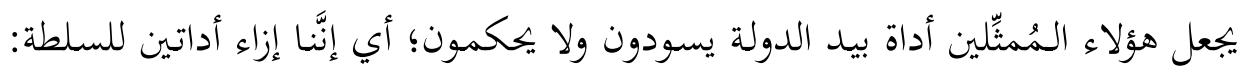

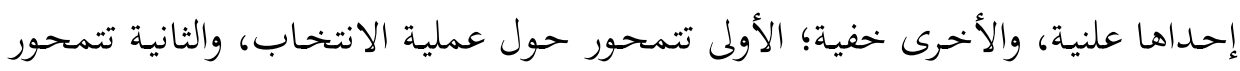

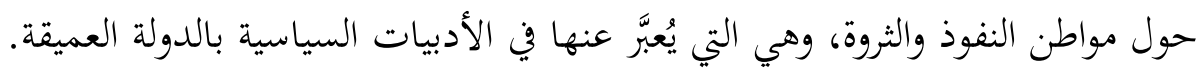

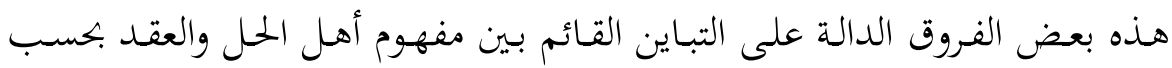

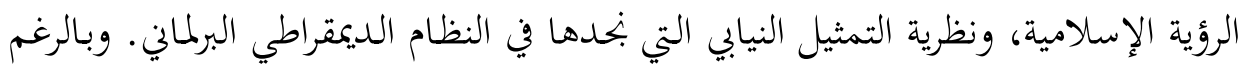

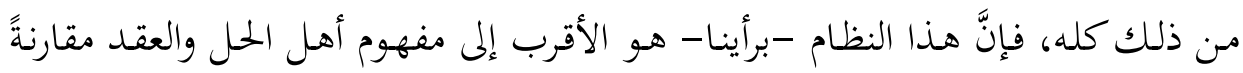

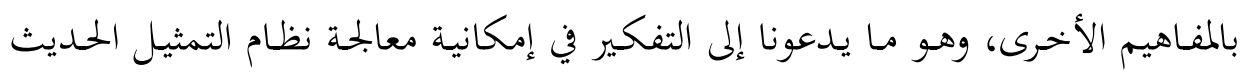

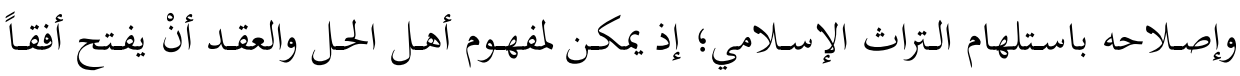
واسعاً لهذا الاستلهام.

\section{Y. أهل الحل والعقد وفق منظور جديد:}

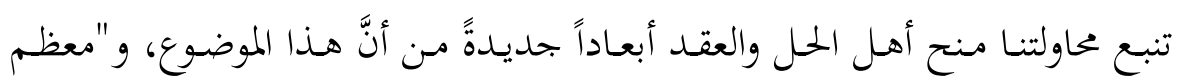

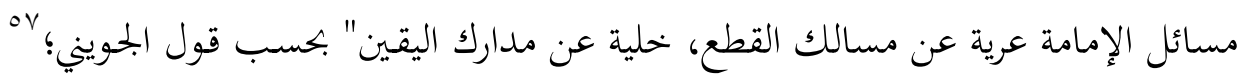

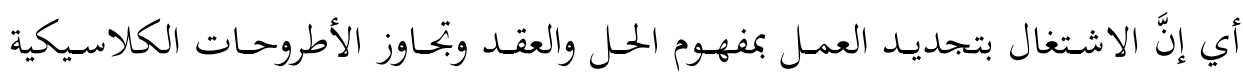

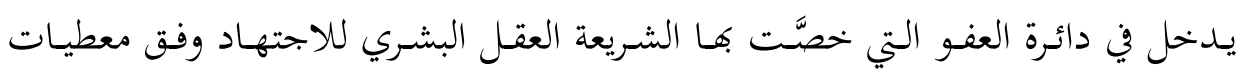

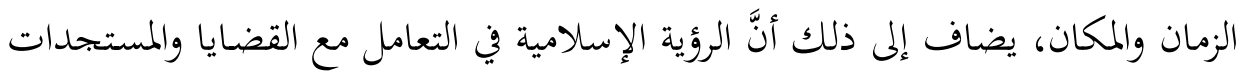

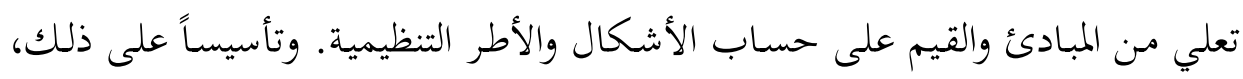

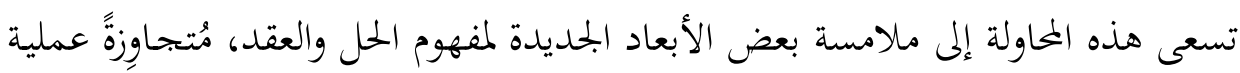

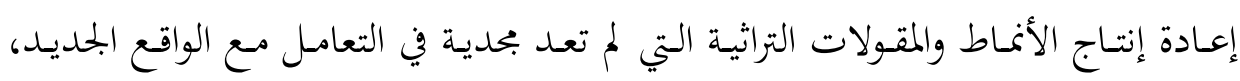




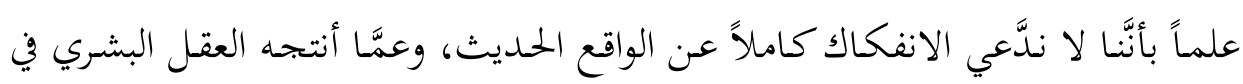
بحال علم السياسة والاجتماع السياسي.

إذن، فالقراءة الجديدة لمفهوم الحل والعقد تنطلق مس الدراسة الواعية لخبرة المفهوم

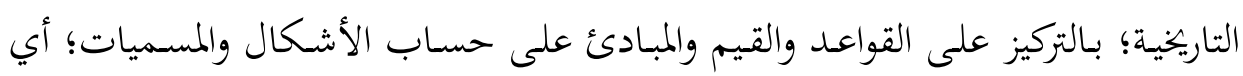
إنَّا لن نعتمد المنهج الاتباعي الذي يقوم على الالتزام بالمبادئ والأطر الفنية الموروثة، وإنَّا

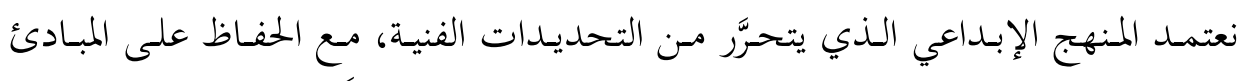

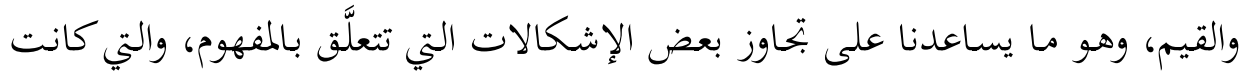

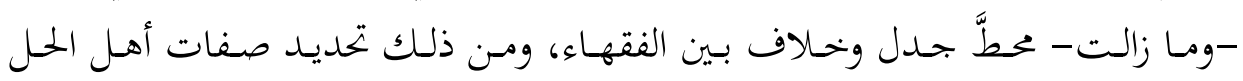
والعقد، والشروط الواجب توافرها فيهم، وأعدادهم.

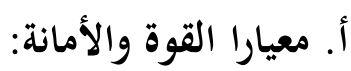

إنَّ هذه النظرة الجحديدة لأهل الحل والعقد لن تدفعنا إلى الحديث عن الجند والعلماء

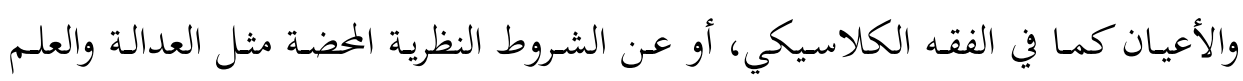

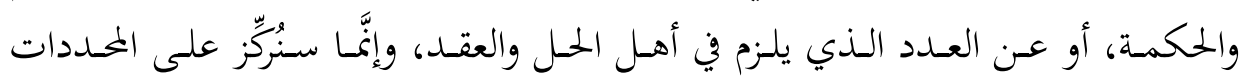

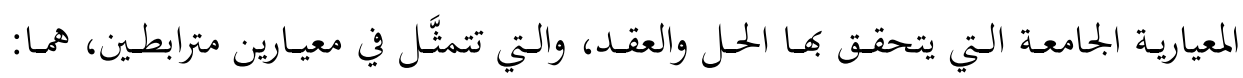

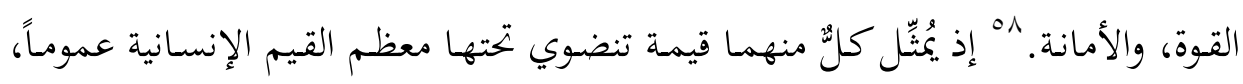

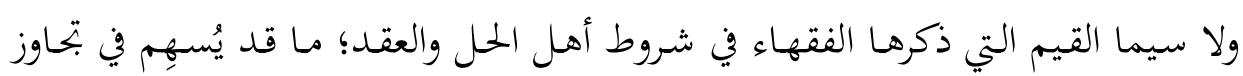

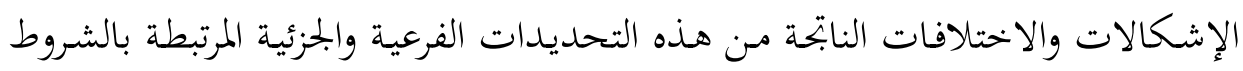
والمواصفات المطلوبة في هذا الأمر.

فالقوة قيمة كلية جامعة لعدد من الإمكانات المادية والمعنوية التي يتمتع بها الإنسان؛

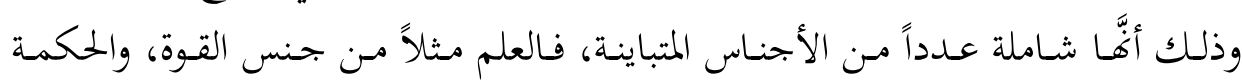

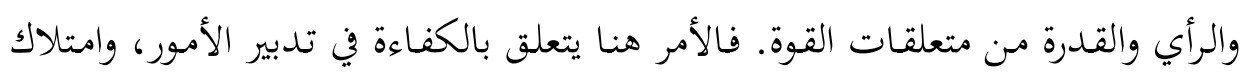

$$
\text { القدرات والخبرات التي تُعِين الإنسان على الفعل الحسن. فلعن. }
$$

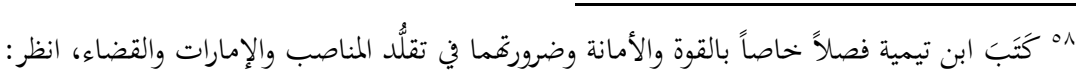

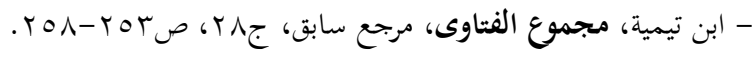


أمَّـا الأمانـة فهي قيمـة أخلاقيـة كليـة، ينـدرج تحتها عـدد مـن القيم الجزئيسة، مثل:

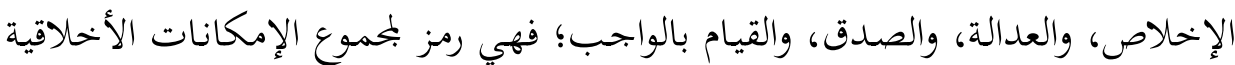

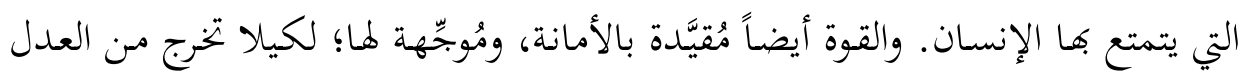
إلى الجور، وذلك بتحديد بحالها وحدودها.

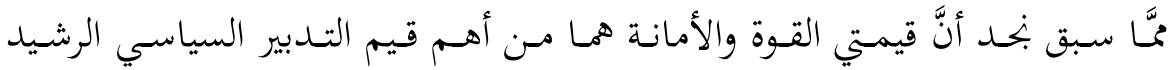

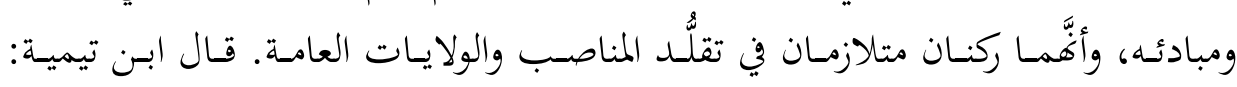

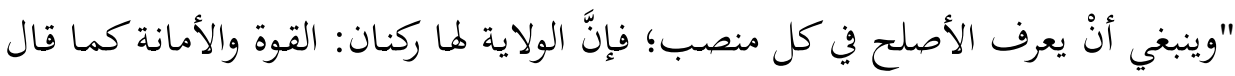

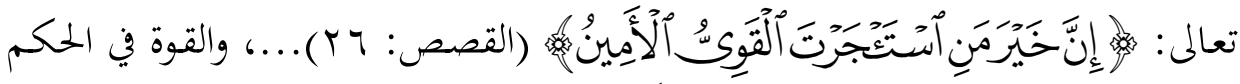

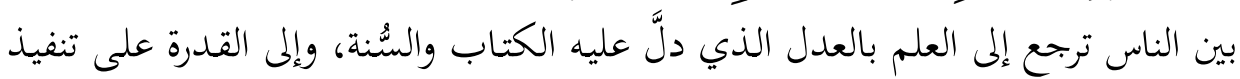

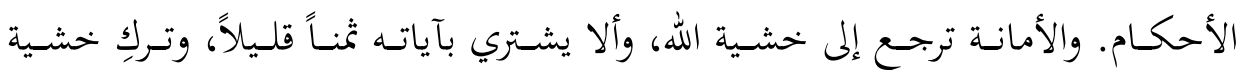
الناس. 1" n

وعلى هذا، فربط العدد في أهل الحل والعقد بمفهوم القوة يعني ربطه بأحد متعلقاته،

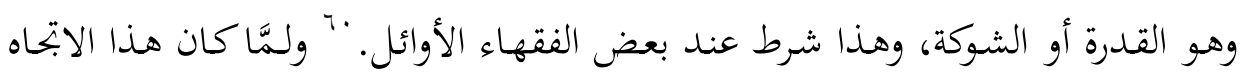

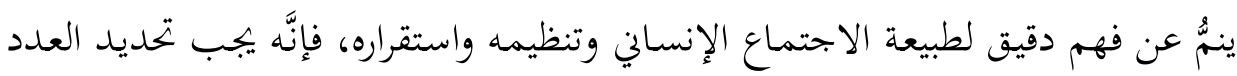

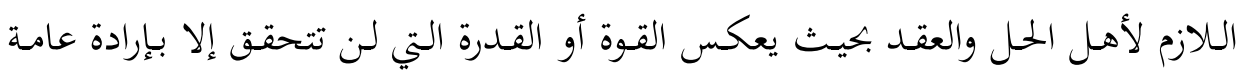

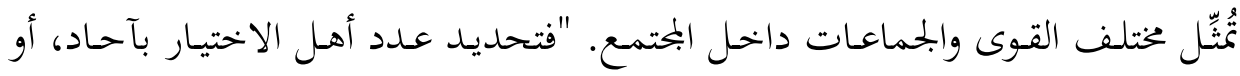

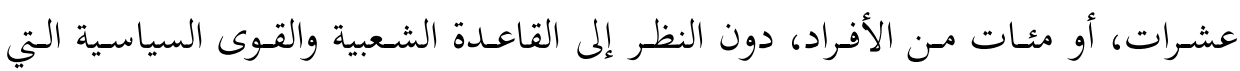

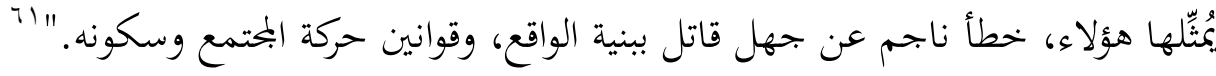

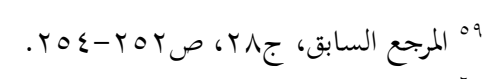

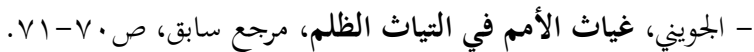

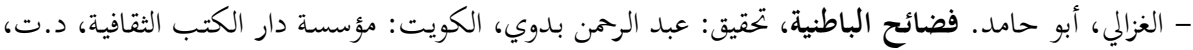


وخلاصـة القول إنَّ النظر إلى قيمتي القوة والأمانة بوصفهما قيماً معياريةً في أهل

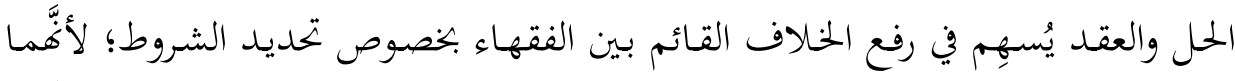

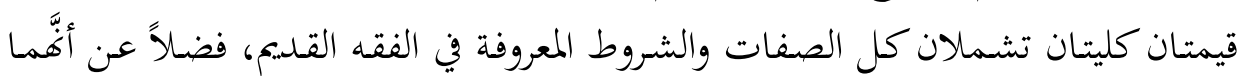

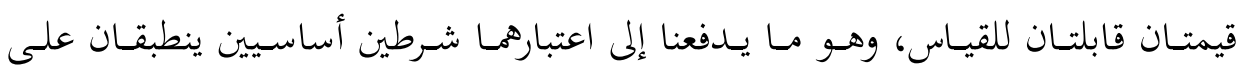
الأشخاص والهيئات معاً.

\section{ب. مؤسسة الحل والعقد ومهامها في العصر الحديث:}

ارتبط مفهوم أهـل الحل والعقــ في سياقاته الاجتماعية والسياسية بتأسيس قواعـد

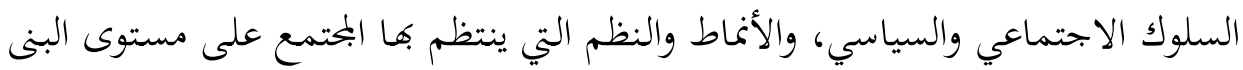

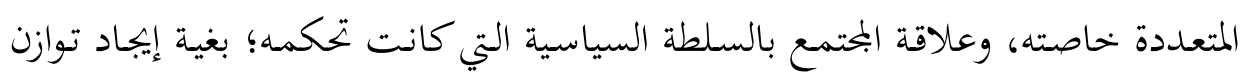

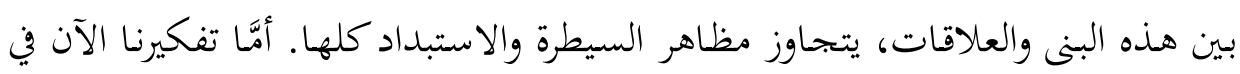

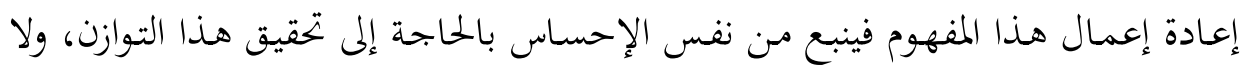

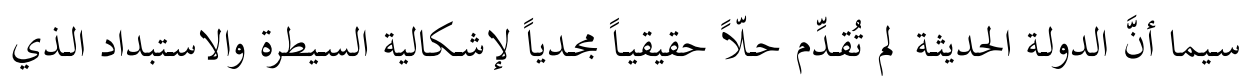

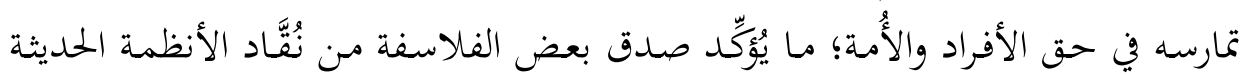

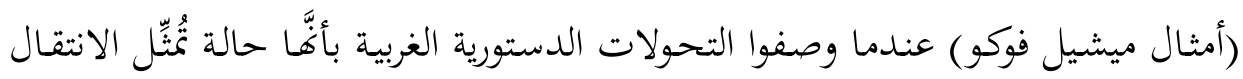

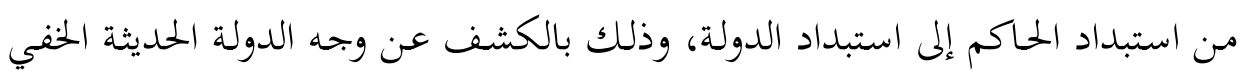

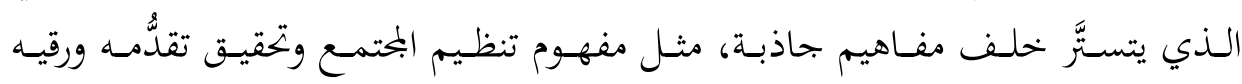

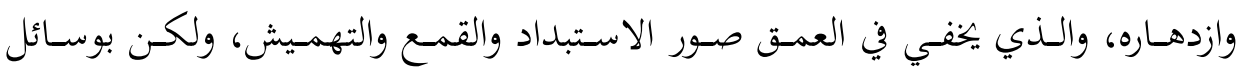
جديدة.

والذي نتطلَّع إليه بتحديـد مؤسسات الحل والعقد يتجاوز المنطق الاتبّاعي الجحامد

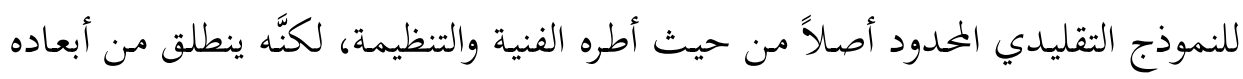

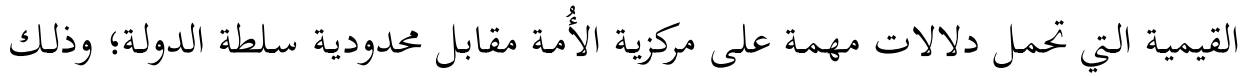

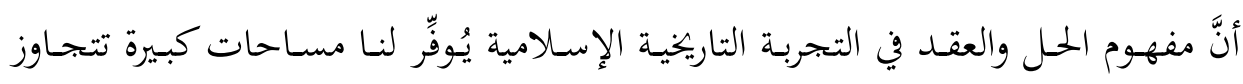

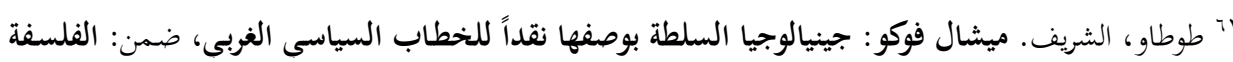

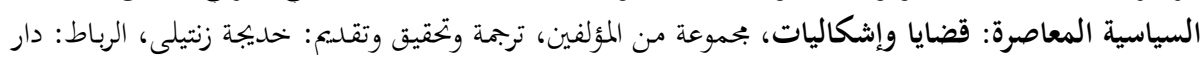




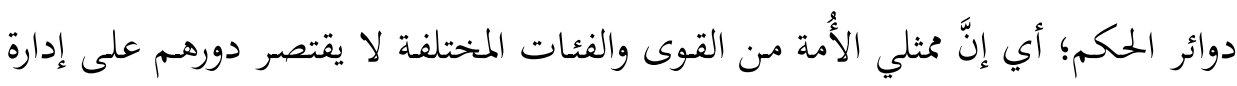

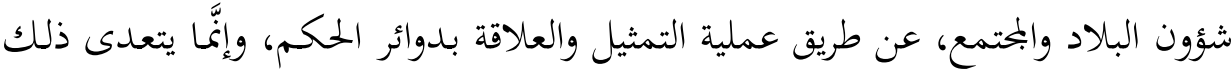

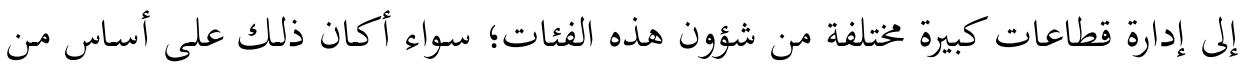

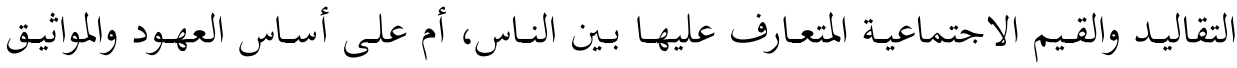

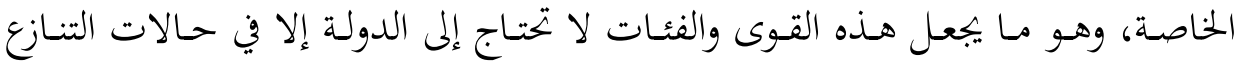
والعنف.

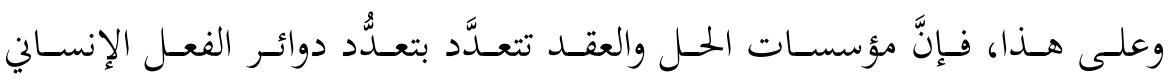

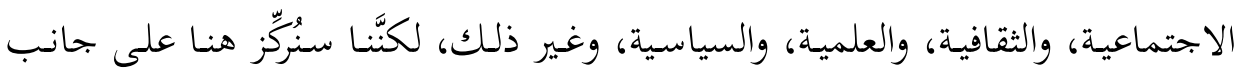

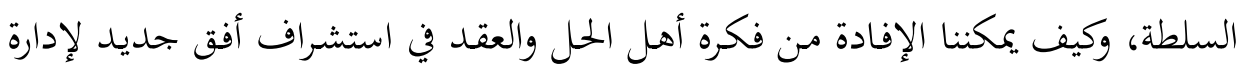

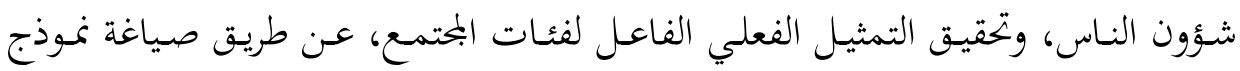

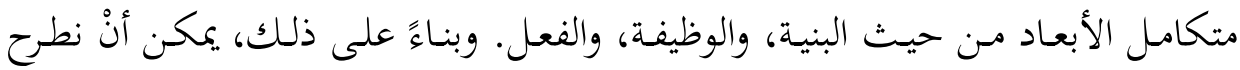

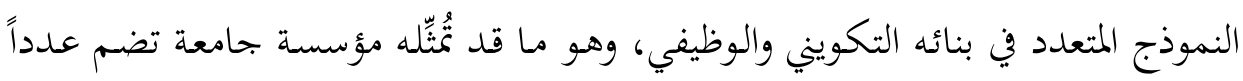

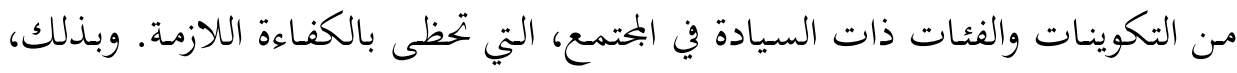

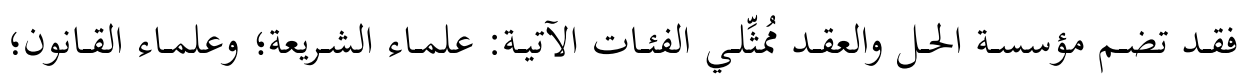

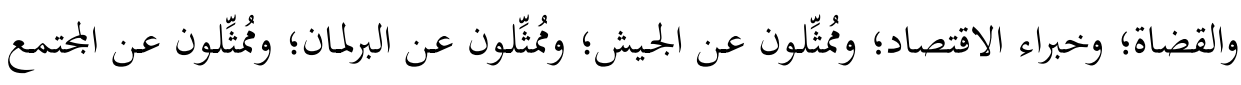
المدني؛ ومُمثّلون عن المؤسسات التنفيذية (الحكومة، رئاسة الدولة). إذن، فمؤسسة الحل والعقد يجب أنْ تكون أهم مؤسسة دستورية في البلاد، بحيث تخظى بدعم شعبي ورسمي، وبتمع بين أصالة المفهوم وإبداعات العقل البشري في بحرّال

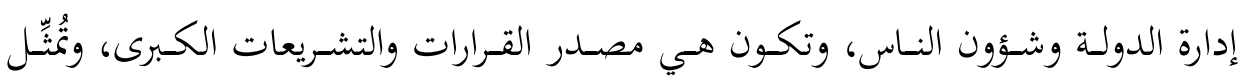

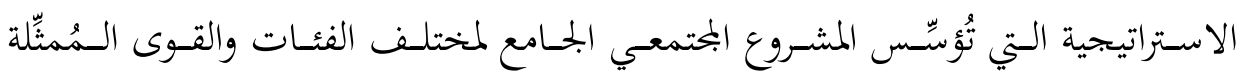

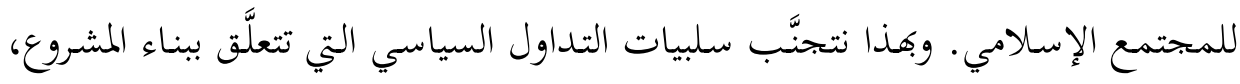

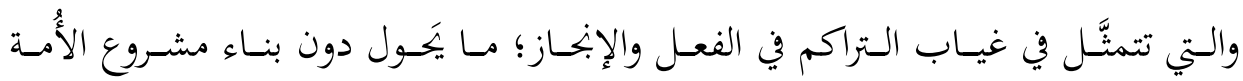

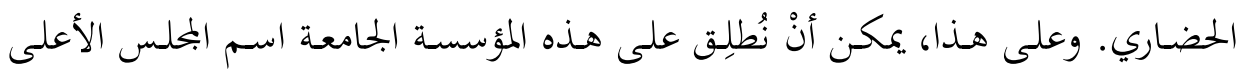


للتشريع والسياسات العامة، بجيث لا يكون هذا البحلس بديلاً عن المؤسسات الأخرى،

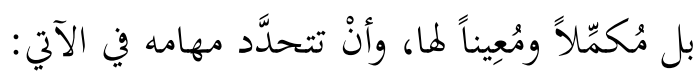
- الموافقة على ترشيحات الانتخابات البرلمانية والرئاسية. - عزل رئيس الحكومة ورئيس الدولة عند مخالفتهما القوانين الدستورية. - الرقابة على المؤسسات التشريعية والتنفيذية، ومحاسبتها. - التصديق على القوانين والتشريعات التي يصدرها البرلمان. - التصديق على مراجعة الدستور وتعديله. - التصديق على المعاهدات والاتفاقيات الدولية. هذه هي بعض الملامح الرئيسة للمؤسسة التي ستتولَّى مهام أهل الحل والعقد مثلما

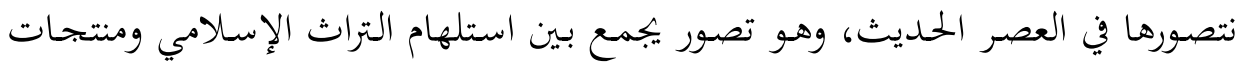

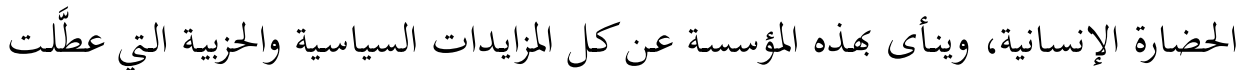

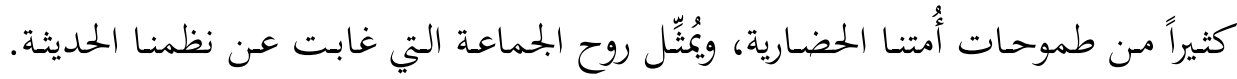

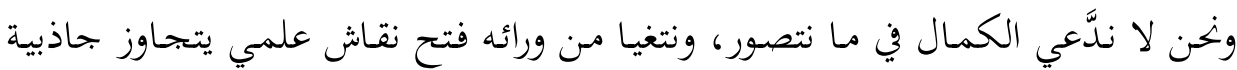

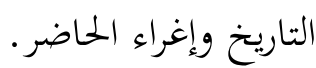

\section{خاتمة:}

خلصت هذه الدراسة إلى نتائج مهمة يمكن أنْ تفضي إلى رؤى وآفاق رحبة في مـا

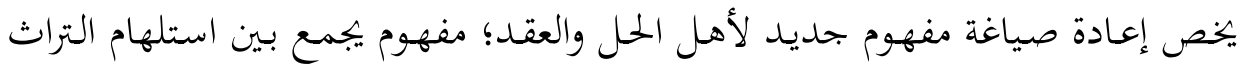

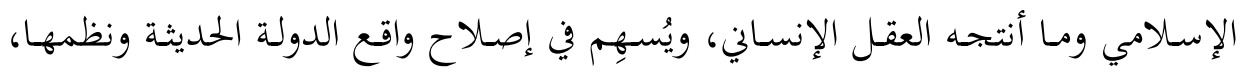

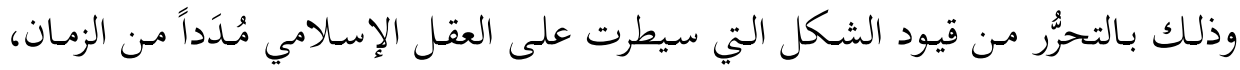

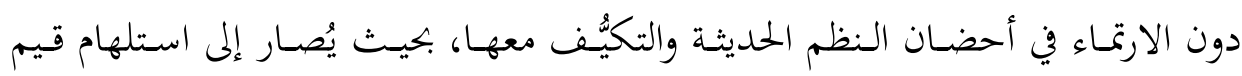

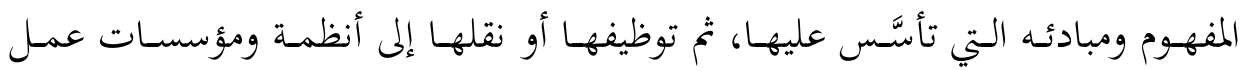

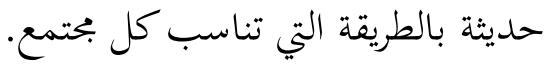


والمُملاحَظ على مفهوم أهل الحل والعقد في التجربة الإسلامية التاريخية أنَّ مداخله

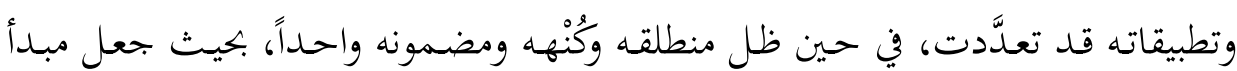

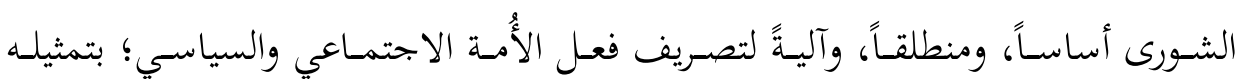
مختلف مككوِّاةًا وفئاتها.

وقد خلصت الدراسة أيضاً إلى أنَّ هذا المفهوم لا يراد به إلغاء الأُمة مثلما حصل في بعض الحقـب التاريخية نتيجـة انحراف الفعل السياسي للحـاكمين، وخروجهم عن أسسه المعهودة، بحيث سادت شرعية التغلُّب والقهر على شرعية الأُمة، واستُخحِّم المفهوم صورياً

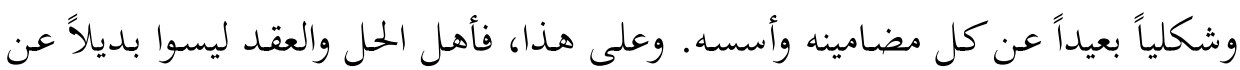

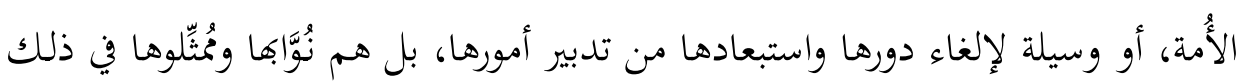
عند تعذُّر ممارسة حقها مباشرةً

ومـا مـن شـكَّ في أنَّ أهـل الحسل والعقـد -في التجربـة الإسـلامية- هـم نتـاج طبيعي

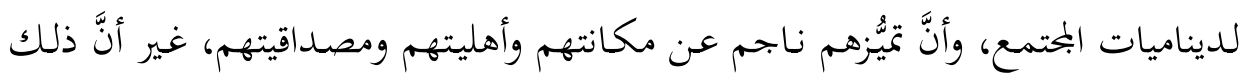

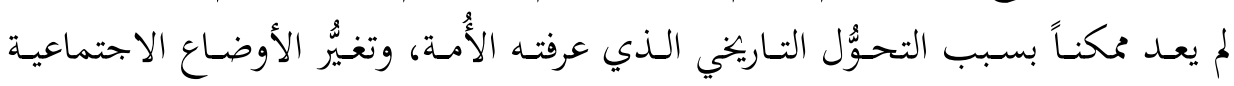

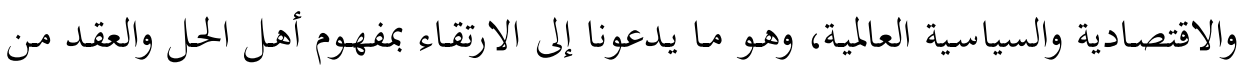

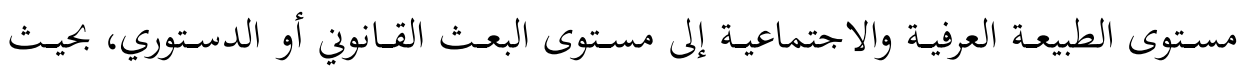

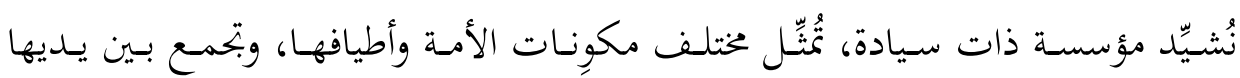

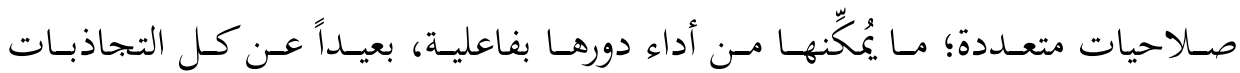
السياسية وسطوة الدولة. 